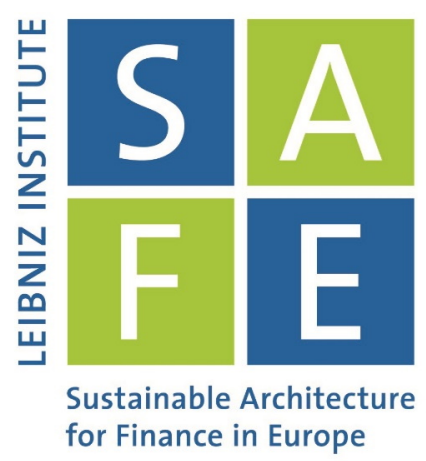

Jannis Bischof | Christian Laux | Christian Leuz

\title{
Accounting for Financial Stability: Bank Disclosure and Loss Recognition in the Financial Crisis
}

SAFE Working Paper No. 283

\section{Leibniz Institute for Financial Research SAFE}

Sustainable Architecture for Finance in Europe 


\title{
Accounting for Financial Stability: Bank Disclosure and Loss Recognition in the Financial Crisis*
}

\author{
Jannis Bischof \\ University of Mannheim \& Leibniz Institute for Financial Research SAFE \\ Christian Laux \\ WU (Vienna University of Economics and Business) \\ Christian Leuz \\ Booth School of Business, University of Chicago \& NBER
}

July 2020

\begin{abstract}
This paper examines banks' disclosures and loss recognition in the financial crisis and identifies several core issues for the link between accounting and financial stability. Our analysis suggests that, going into the financial crisis, banks' disclosures about relevant risk exposures were relatively sparse. Such disclosures came later after major concerns about banks' exposures had arisen in markets. Similarly, the recognition of loan losses was relatively slow and delayed relative to prevailing market expectations. Among the possible explanations for this evidence, our analysis suggests that banks' reporting incentives played a key role, which has important implications for bank supervision and the new expected loss model for loan accounting. We also provide evidence that shielding regulatory capital from accounting losses through prudential filters can dampen banks' incentives for corrective actions. Overall, our analysis reveals several important challenges if accounting and financial reporting are to contribute to financial stability.

JEL classification: $\quad$ G21, G22, G28, G32, G38, K22, M41, M42, M48

Key words: $\quad$ Banks, Financial crisis, Financial stability, Disclosure, Loan loss accounting, Expected credit losses, Incurred loss model, Prudential filter, Fair value accounting

\footnotetext{
* This paper was prepared for the $10^{\text {th }}$ Anniversary of Financial Crisis Conference. We are grateful for comments and suggestions made by Peter Fiechter, Joao Granja, Luzi Hail, Anil Kashyap, Sehwa Kim, Thomas Rauter, Stephen Ryan, Tano Santos, Rene Stulz, and Luigi Zingales. We also thank conference participants at the $10^{\text {th }}$ Anniversary of Financial Crisis Conference at Chicago Booth, the 2019 Meeting of the Verein fuer Socialpolitik (Ausschuss Unternehmensrechnung) at University of Basel, the 2017 Macro Financial Modeling Meeting in New York, and seminar participants at the Frankfurt School of Finance and Management, Office of Financial Research, Université de Lausanne, Universidad Torcuato Di Tella, University of Mannheim, University of Texas at Dallas, University of Vienna, and WHU Vallendar for providing helpful comments. We thank Patricia Breuer, Vincent Giese, Tom Kim, Igor Kuznetsov, Thomas Rauter, Nicolas Rudolf and Steven Vanhaverbeke for their excellent research assistance. Christian Leuz gratefully acknowledges financial support by the Sondheimer Family Charitable Foundation and the Initiative on Global Markets. Jannis Bischof gratefully acknowledges research support from the Leibniz Institute for Financial Research SAFE and funding from the German Research Foundation (DFG) under the CRC TRR 266 program ("Accounting for Transparency"), Project-ID 403041268.
} 


\section{Introduction}

The 2008 financial crisis set off a major debate about the role of accounting for financial stability. Early in the crisis, policymakers and commentators made strong claims about fair-value or mark-to-market accounting (FVA), arguing it exacerbated the crisis by facilitating excessive leverage in booms and leading to contagion and downward spirals in busts. Later, the G20 raised concerns about banks' accounting for loan losses and the incurred loss model, arguing it delays loss recognition and corrective actions by banks. There is also an ongoing debate on the role of prudential filters that shield regulatory capital from fair value (FV) changes of certain assets. ${ }^{1}$

For all these debates, empirical evidence on the links between accounting and financial stability is important. With respect to the role of FVA, a substantial body of evidence has emerged since the crisis and this work provides many important insights. ${ }^{2}$ However, the heavy focus on FVA early on in the public debate has diverted attention from other accounting and reporting issues that also matter for financial stability. In fact, several early failures were banks that reported most of their assets at amortized cost, rather than at FV (e.g., IKB and Northern Rock), suggesting that questions on the link between accounting and financial stability extend beyond FVA.

The goal of this paper is to highlight accounting issues that have received less attention, yet are central when it comes to financial stability. We take the primary reasons for several prominent bank failures in Europe and the U.S. as our starting point and ask what role accounting and financial reporting could have played in these failures (for better or worse). The leading

1 While Basel III abolished filters shielding regulatory capital from FV changes of available-for-sale (AFS) debt securities, after push back, the U.S. gave all but the largest ("advanced approach") bank holding companies an irrevocable choice.

2 See, e.g., Ryan (2008), Laux and Leuz (2010), Bhat et al. (2011), Badertscher et al. (2012), Bowen and Khan (2014), Xie (2016), and Laux and Rauter (2017) for studies on the role of FVA for banks. For evidence on the role of FVA for insurers, see Ellul et al. (2014, 2015), Merrill et al. (2014), and Khan et al. (2019). 
(immediate) cause for bank failures during the crisis was high leverage coupled with short-term funding by sophisticated (institutional) investors. Such funding structures when used to finance risky assets can be very instable and expose banks to runs. Therefore, banks' disclosures about exposures to risky assets and funding structures could potentially play an important role for banks' stability. Timely disclosures could discipline banks and provide incentives for banks to take corrective actions early. However, disclosures of losses or exposures to troubled assets could also trigger a bank run, as could corrective actions that investors view as signs of weakness (e.g., a dividend cut). Thus, there are tradeoffs. Similar tradeoffs arise for a timely recognition of losses on bank assets (e.g., impairments on troubled loans). Here, the concerns are particularly severe because write-downs on impaired assets reduce bank capital, which is closely monitored by investors and has regulatory implications. To mitigate this impact and the potential for downward spirals, bank regulators can (and do) shield regulatory capital from losses with prudential filters. However, prudential filters could also weaken banks' incentives to take early corrective actions.

These three issues, bank disclosures, loan loss recognition, and prudential filters, are the focus of this paper. We begin by examining when major banks first disclosed their exposures to troubled assets and how the market reacted to these disclosures. At the start of a crisis, disclosure choices are particularly important. On the one hand, more extensive disclosures provide relevant information about the exposures to troubled assets, which can reduce uncertainty. On the other hand, more disclosures could trigger bank runs and set off a panic among investors (e.g., Morris and Shin, 2002; Goldstein and Sapra, 2014). Thus, the role of bank disclosures for financial stability is not obvious. ${ }^{3}$ However, little is known about the disclosures of key banks in the crisis 2007-2008. When did systemically important banks or banks that failed in the crisis provide

3 See Acharya and Ryan (2016) for a discussion of different views on transparency (opacity) for financial stability. 
relevant information to market participants? How did markets respond to these disclosures? Did the disclosures make matters worse and contribute to the uncertainty in markets?

We investigate the evolution of disclosures for 10 U.S. banks that were important in the crisis because of size, systemic relevance, or public attention when they failed. The disclosures of these banks arguably have the greatest potential impact on financial stability and could have substantial negative information spillovers. We complement the sample of U.S. banks with 10 European banks, some of which failed early on and hence could also have played an important informational role in the crisis. For both groups of banks, we find that disclosures about their exposures to assets that played a key role in the crisis (e.g., subprime) came late, and often had to be substantially revised (upwards) as the crisis continued. We find little evidence (e.g., in CDS prices) that the disclosures set off problems or destabilized banks. It is not possible from this analysis to conclude that more forthcoming disclosures would have been better or could not have had detrimental effects. But it clearly emerges that markets do not "wait" for bank disclosures when a crisis starts to unfold and market conditions deteriorate. In this situation, withholding information is unlikely to be helpful. Banks' disclosures are not the only source of information that investors use to learn about banks' exposures and financial problems. Incomplete disclosures as well as repeated upward revisions in banks' exposures or losses can make matters worse by creating externalities for healthy banks through an erosion of investor trust. While we cannot explicitly show a deterioration of trust due to banks' disclosures, our evidence is consistent with it. Thus, one important lesson from the crisis is that assuring the market that banks' disclosures are reliable is critical for financial stability, in particular, early on in a crisis. ${ }^{4}$ Reliability is important whatever the level of detail, including

4 Of course, disclosures and stress tests alone cannot solve potential refinancing or debt overhang problems. However, reliable information can make it easier for a bank that is solvent to raise additional capital at the onset of a crisis, and unreliable disclosures can put it at risk of adverse market reactions. Ben-David et al. (2019) document 
for simple disclosures solely stating that exposures to certain assets are insignificant.

Second, we investigate the timeliness and magnitude of banks' loan loss recognition. In the aftermath of the crisis, the recognition of loan losses was criticized as being too small and coming too late, and prevailing accounting rules were seen as a key reason for the delay (e.g., Dugan, 2009; Financial Stability Forum 2009; Barth and Landsman, 2010; Basel Committee on Banking Supervision, 2011; Curry, 2013). In response to this criticism, the standard setters changed the accounting rules for loans from an "incurred" to a more forward-looking "expected" credit loss model. Irrespective of this change, we lack evidence on key questions: How timely were banks in recognizing losses during the crisis? Were they constrained by the prevailing accounting rules and what role did banks' reporting incentives play? Understanding these questions is important, not the least because loans are by far the largest asset class on banks' balance sheets.

We examine the loan loss recognition and related loan loss disclosures of 237 U.S. banks in the crisis. ${ }^{5}$ A key challenge for this analysis is finding an appropriate benchmark against which to assess the level and timeliness of banks' loss recognition. Doing so is also critical to separate the influence of the accounting rules and banks' reporting incentives. We proceed in several steps. We first benchmark banks' loan loss recognition at the height of the crisis against concurrent market estimates of future loan losses. We find that loan loss provisions and write-offs at the height of the crisis were small relative to concurrent market expectations and that market estimates were broadly in line with realized losses. ${ }^{6}$

that distressed banks have incentives to take actions that reduce leverage during financial crises, e.g., through equity issuances. See also our analysis of corrective actions in Section 4.

5 Prior studies (e.g., Vyas, 2011; Badertscher et al., 2014) examine other-than-temporary impairments by banks during the crisis, but also include assets recorded at FV. The literature that examines the timeliness of loan loss provisions goes back at least to Beaver et al. (1989).

6 We recognize that ex post realized losses reflect hindsight as well as endogenous crisis responses. But they are still a useful benchmark to assess the magnitude of the ex-ante market estimates. 
Next, we analyze banks' disclosures of loan losses in 8-K filings as well as via FVs in the notes of the financial statements. This analysis exploits that disclosures of future loan losses do not follow the same rules as the recognition of loan losses and hence allows us to learn about banks' reporting incentives. We perform this analysis at the height of the crisis, when it was clear that the U.S. economy was headed for a recession and that banks would likely suffer substantial loan losses. Thus, if the accounting rules indeed "constrained" banks to recognize loan losses in a timely fashion and yet banks wanted to inform investors, we should find timelier disclosures of expected future loan losses, for instance, in FV estimates of the loans in the notes or in 8-K filings. We find that such disclosures are very rare. In addition, we find evidence that banks' reporting incentives played an important role in the delay of their loss recognition.

We emphasize that these findings do not necessarily imply misreporting. It is difficult to know to what extent losses were incurred under the prevailing rules and what banks' (internal) loss expectations were at the time. For this reason, we complement the analysis of reporting incentives with a study of all large European banks that were subject to an Asset Quality Review (AQR) by the European Central Bank (ECB). In this audit exercise, the ECB assessed banks' loan valuation based on the extant rules. These valuation adjustments due to the AQR speak more directly to the question of whether the prevailing rules constrained impairments of banks' loan portfolios. The evidence suggests that (European) banks used discretion in the rules to over-report the values of their loan portfolios or to under-report their loan losses. We also find that the magnitude of AQR adjustments (i.e., the underreporting of loan losses) is associated with banks' regulatory capital constraints. Thus, the evidence lends further support to our interpretation that reporting incentives affected banks' loan loss recognition during the crisis.

Third, we examine the role of prudential filters for banks' corrective actions. Such filters 
mitigate the impact of certain losses on regulatory capital and hence reduce the potential for fire sales and downward spirals. However, filtering certain losses could also delay banks' corrective actions and provide incentives to hold on to assets that deteriorated in value (e.g., Laux and Leuz, 2009). ${ }^{7}$ Prior studies investigate the effect of prudential filters for FV losses on banks' portfolio allocations and earnings volatility around their introduction and key accounting changes (Beatty, 1995; Hodder et al., 2002) and around the removal of filters for certain U.S. banks in 2014 (Chircop and Novotny-Farkas, 2016; Hamilton, 2018; and Kim el al., 2019). But we lack evidence on the following important questions for bank regulation: Do prudential filters dampen the incentives for banks to take corrective actions? How do these incentive effects differ over the business cycle?

We exploit cross-country, time-series as well as within-country variation in prudential filters for FV losses on Available-for-Sale (AFS) securities to analyze the association between AFS results and corrective actions, such as cutting dividends, reducing risk-weighted assets or leverage, or raising new capital, in different AFS filter regimes. We find that this association is weaker when prudential filters shield banks' regulatory capital. Thus, with filters, banks appear to be less inclined to take corrective actions in response to AFS losses. This result highlights that muting the impact of losses on regulatory capital is a double-edged sword and that the interaction between accounting and the computation of regulatory capital deserves careful attention.

Overall, the picture on the role of accounting for financial stability that emerges ten years after the crisis is quite different from the picture during the crisis, which was dominated by concerns about FV write-downs triggering downward spirals. An overarching theme that comes through in all our analyses is that banks were reluctant to communicate losses, be it in their disclosures or

7 While we are not aware of prior evidence for banks, there is evidence that insurers for which FV losses have more direct regulatory implications are more likely to sell downgraded assets with price declines (Merrill et al., 2014; Ellul et al., 2015). 
their loss recognition (e.g., provisions and impairments). These reporting incentives are important for our understanding of banks' reporting behavior during the crisis, and they deserve greater attention in the regulatory debate, not the least because banks could use discretion inherent in the accounting rules and regulatory requirements, rather than to engage in real corrective actions.

Aside from this more general insight, our paper contributes to the literature in several ways. First, we provide a systematic review of key banks' disclosures as the crisis unfolded. The observation that the first crisis-related disclosures came relatively late in the timeline of the crisis is important and novel. Perhaps more importantly, we show that these disclosures did not trigger major adverse market reactions when compared to other key information events in the crisis. This evidence is important in light of the often-expressed concern that disclosures could also have adverse consequences and trigger panics.

Second, we provide novel evidence that banks' loan loss recognition came late relative to prevailing market expectations at the time. This evidence on loan loss recognition resembles and reinforces our evidence on bank disclosures early in the crisis. Both highlight that banks are reluctant to recognize or disclose losses, and both point to reporting incentives as a key factor. Our AQR analysis corroborates this interpretation. To our knowledge, we are the first to study the implications of the ECB's AQR with respect to the timeliness of banks' loss recognition. Overall, our evidence on the role of incentives has important implications in light of recent changes in the accounting rules and the debate about the loan loss model following the crisis.

Third, we are the first to analyze the link between prudential filters that shield regulatory capital from FV losses and banks' incentives to take corrective actions. Our evidence shows that prudential filters can have side effects. The evidence questions the notion that prudential filters necessarily foster financial stability and, more generally, illustrates the tradeoff between ex post 
crisis mitigation and ex ante incentives, which is so central to bank supervision.

Our study highlights a number of thorny problems when it comes to the interaction of accounting and financial stability. We acknowledge that, in some cases, our evidence allows us to provide conjectures only. We encourage future research to tackle these important issues. Towards this end, we identify several issues that deserve more attention going forward. One of these issues is the link between accounting measurement and bank funding structure. For example, debt securities are recognized at historical cost if they are held to maturity for the collection of cash flows. A common justification for this accounting treatment is that market values are not relevant in this case (e.g., ABA, 2009). However, with short-term funding, including wholesale deposits, banks essentially have to continuously roll over their funding and such refinancing is akin to repeatedly selling a claim on a pool of assets at current market prices. Thus, a bank's ability to hold assets to maturity or for the collection of cash flows does depend on interim market prices when it needs to roll over its funding. Therefore, banks' funding structures are potentially more relevant for accounting measurement than either management's intent or the bank's business model, both of which is what the accounting standards reference.

In Section 2, we analyze banks' financial disclosures early in the crisis as well as market reactions to them. Section 3 examines the timing and magnitude of banks' loss recognition during the crisis as well as potential reasons for the apparent delay. In Section 4, we analyze banks' corrective actions in response to FV losses and how prudential filters affect these actions. Section 5 concludes and points to several issues for future research. 


\section{Bank disclosures: Evolution, market reactions, and financial stability}

Disclosures play an important role in providing information about a built-up of risks or concentration of exposures on banks' balance sheets, but also about banks' funding structure and their ability to absorb shocks. This information provides a basis for valuing claims issued by banks as well as for decisions to withdraw deposits or roll over debt. At the start of a crisis, disclosures can provide useful information to the extent banks have material exposures to the relevant assets (e.g., subprime in 2007 and 2008). Disclosures about such exposures can reduce uncertainty (e.g., help distinguish between solvent and insolvent banks), but also trigger bank runs and set off a panic among investors (e.g., Morris and Shin, 2002; Goldstein and Sapra, 2014).

In this section, we focus on two important issues that have received little attention in research on the financial crisis 2007-2008. The first issue is the timing of banks' disclosures, in particular those about banks' exposures to subprime assets and losses. When did banks provide relevant information to market participants? Were banks' disclosures proactive or reactive relative to other information in the market? With these questions in mind, we delineate the evolution of disclosures relative to the timeline of the crisis. The second issue is how markets responded to these disclosures. Did the disclosures make matters worse and contribute to the uncertainty in markets in 2007-2008? To shed some light on this issue, we investigate market reactions to banks' disclosures. A key challenge for this analysis is the appropriate benchmark against which to assess the level of disclosures and market reactions. Banks can disclose only what they know and market reactions depend on prior expectations. As the crisis evolved quickly, the information of bank managers and market expectations changed quickly as well. Thus, it is important to consider the broader economic and informational environment when assessing banks' disclosures and the corresponding market reactions early in the financial crisis. 


\subsection{Evidence on the evolution of crisis-related disclosures}

To investigate the evolution of disclosures over the crisis, we focus on 10 U.S. banks that were important in the crisis based on size, systemic relevance, or public attention (when they failed). ${ }^{8}$ The market capitalization of these banks comprises nearly $50 \%$ of the total market capitalization and $71 \%$ of total book assets of all listed U.S. banks in 2008-Q1. The disclosures of these banks are of particular relevance for our analysis because they have arguably the greatest potential impact on financial stability or the highest risk of negative information spillovers. We complement the sample of U.S. banks by 10 European banks, including smaller banks that failed early on in the crisis, to investigate whether their disclosures differed. In total, 12 of the 20 sample banks faced bailouts, takeovers, bank runs, or bankruptcies.

In Table 1, we provide a list of these banks, including an overview of the timing and content of their disclosures about subprime exposures, funding structures, and interest rate sensitivities between 2006-Q4 and 2008-Q4. The table also includes information about the use of discretionary accounting choices related to FVA, the timing of corrective actions, and subsequent litigation that banks faced for misleading statements or disclosures.

Prior to the crisis, all sample banks disclosed at least some basic information about leverage, funding gaps, or interest rate risk. This information was not disclosed in a standardized way. Nevertheless, investors should have been able to understand that banks were highly levered and often funded short-term. That said, we find few detailed disclosures about factors that turned out to be critical in the crisis. The rules at the time did not require specific disclosures on banks' direct

8 This sample includes five bank holding companies (Bank of America, Citigroup, JP Morgan, Wachovia, and Washington Mutual) and five investment banks (Bear Stearns, Goldman, Lehman, Merrill Lynch, and Morgan Stanley). The latter are required to file financial reports (e.g., Form 10-K) with the SEC and their broker/dealer subsidiaries are regulated by the SEC. Bank holding companies are regulated by the Federal Reserve Board and have regulatory reporting requirements (e.g., Form Y-9C) in addition to their SEC reporting. 
and indirect subprime exposures, including subprime residential mortgage backed securities (RMBSs) and collateralized debt obligations (CDOs). ${ }^{9}$

Only two of our sample banks, BNP and JP Morgan, voluntarily provided, albeit very basic, information about their exposures to the subprime mortgage market in their 2006 annual reports. None of the other sample banks disclosed specific information related to their exposures to the subprime mortgage market until September 2007. This lack of disclosure is particularly noteworthy considering that there were several signs suggesting a deteriorating subprime mortgage market (see also Gorton, 2008; Ryan, 2008). Prior to September 2007, several financial institutions had already failed and subprime originators such as New Century Financial had announced refinancing problems; rating agencies had downgraded several hundred subprime-related MBS; the ABS.HE index for subprime bonds and the S\&P/Case-Shiller home price index had experienced a significant decline in value; and BNP Paribas had announced in August 2007 that it closed three investment funds because it could no longer value its assets due to problems in the U.S. mortgage market.

The apparent lack of disclosures by U.S. banks prompted the SEC to raise questions about their exposures to the subprime market in a series of comment letters to U.S. investment banks in regards to their 10-K or 10-Q filings. On August 1, 2007, Lehman, whose share price had declined by nearly $30 \%$ from its peak in February 2007, was the first bank to receive such a comment letter from the SEC, asking about its exposure to subprime residential mortgages. Lehman responded and the SEC closed the matter on September 19, 2007, writing: "We note that you believe the

9 It was possible to back out information on the amount of highly rated nongovernment and nonagency securities held by U.S. bank holding companies using regulatory FR Y-9C filings. However, similar reporting requirements did not exist for U.S. investment banks requirements (Erel et al., 2013). More generally, bank holding companies provided much more detail on exposures in their regulatory reporting than investment banks were required to reveal under SEC regulation. 
likelihood is remote that the amount, or range, of reasonably possible losses in connection with your involvement with subprime residential mortgage loans will be material to your consolidated financial condition ... We have no further comments at this time." $" 10$

Our U.S. sample banks started to provide explicit and more systematic disclosures on their subprime exposures in September 2007. After Goldman Sachs had reported net gains from its subprime investments in its 8-K filing on September 20, Merrill Lynch was the first major bank, along with Washington Mutual, to provide (some) negative financial information in its 8-K filing on October 5. Merrill's 8-K filing revealed total impairments on CDOs, other subprime mortgages, and non-investment grade lending commitments of $\$ 4.5$ billion. The disclosure was limited to the impairment amount and highlighted Merrill's effort to reduce investments in similar asset classes; it did not yet disclose any details about its remaining exposures. The subsequent third-quarter earnings announcement published on October 24, 2007 included write-downs of $\$ 7.9$ billion on CDOs and provided more detailed information about Merrill's exposure to subprime mortgagerelated securities in the footnotes to the 10-Q report. These disclosures raised concerns about the need for further write-downs at Merrill and its peers. ${ }^{11}$ Merrill's competitors followed with detailed disclosures about their subprime exposures in November 2007 (Citigroup on November 5, Bank of America on November 9, Bear Stearns and Lehman on November 14).

The picture for our European sample banks resembles the one for the U.S. banks. The initial disclosures about key exposures came late and provided little detail. Similar to Lehman's response to the SEC, press releases by European banks in August 2007 seemed vague and intended to reassure investors that exposures to the subprime market were either small or under control (e.g.,

${ }^{10}$ SEC, Letter to Lehman Brothers Holdings Inc., September 19, 2007, File No. 1-09466.

${ }^{11}$ For instance, the Economist asked on October 28, 2007, "Is Merrill the tip of the iceberg? If so, who is the Titanic?" 
"no negative impact from subprime", "not exposed", "well protected", "limited exposure"). ${ }^{12}$ None of the European sample banks provided an amount for their subprime exposure at this time. ${ }^{13}$ The Committee of European Banking Supervisors (CEBS), an independent advisory group on EU banking supervision, conducted a systematic review of EU banks' risk disclosures in their 2007 financial reports. The subsequent CEBS Transparency Report (2008) criticizes the lack of specific disclosures, especially about banks' activities related to securitized mortgage loans, their risk management or bank-specific problems encountered in the subprime crisis, echoing our findings.

During the crisis, U.S. and European banks not only increased the amount and detail of their disclosures about key exposures, but they also revised their earlier disclosures, sometimes more than once, often making new disclosures that were at least seemingly at odds with their earlier statements. For instance, Bear Stearns provided a relatively optimistic outlook in its 10-Q report in November 2007, but then reported its first-ever quarterly loss in December 2007. Again, Merrill Lynch is an interesting example. In addition to increasing its CDO and subprime charge for the third quarter 2007 from $\$ 4.5$ billion to $\$ 7.9$ billion within three weeks, Merrill initially disclosed $\$ 5.7$ billion of subprime mortgage-related net exposures in its 8-K report on October 24, 2007, only to revise this number to $\$ 46$ billion in gross exposures three months later when the hedge effectiveness of the net position became more uncertain. This example not only illustrates the revisions, but also the often non-linear and hard-to-predict nature of the underlying exposures. We further note that, at the time, the disclosure of gross positions was voluntary for investment banks (whereas bank holding companies had to report gross exposures in regulatory FR Y-9C reports).

${ }^{12}$ See press releases by Hypo Real Estate on August 3, Deutsche Bank on August 4, Dexia on August 6, and BNP on August 13, 2007.

${ }^{13}$ UBS is a good example. It did not provide quantitative information until fall 2007. On October 30, 2007, UBS disclosed the aggregate net exposure to the U.S. mortgage markets as well as current impairment charges in its third-quarter management report. Later in its 2007 Annual Report, it provided more quantitative information about the different types of exposures to the U.S. mortgage market; the report was published on March 18, 2008. 
An illustrative example among the European banks is Germany's IKB. It was bailed out on August 1, 2007, just about one month after it published its annual report on June 28, 2007. This report did not provide any explicit indication of the bank's subprime exposures, which stemmed primarily from liquidity guarantees to a special-purpose conduit, Rhineland Funding, which was heavily invested in the subprime market. IKB mentioned these subprime exposures for the first time in its announcement of first-quarter results on July 20, 2007, describing these exposures as "insignificant." Only ten days later, on July 30, 2007, the bank issued a profit warning, revealing more details about its dealings with Rhineland Funding and the corresponding exposures. This later disclosure put a question mark behind the initial statement that subprime exposures were insignificant. Interestingly, key lenders, including Deutsche Bank, had already cut IKB's credit lines before the July 30 disclosure (e.g., Financial Times, 2007).

\subsection{Evidence on market responses to bank disclosures and fundamental events}

To investigate how markets responded to bank disclosures, we examine 5-year CDS spreads and stock returns for the 10 U.S. sample banks around key disclosures and other economic events in 2007. We focus on the U.S. sample because we lack reliable CDS spreads for most of the European sample banks. CDS pricing data comes from IHS Markit and stock price data comes from CRSP. We begin by simply plotting 5-year CDS spreads for the nine U.S. banks that started disclosing in fall 2007 in event time (Figure 1, Panel A). ${ }^{14}$

The Dow Jones U.S. Bank Index started to decline in May 2007, losing more than $27 \%$ in value until December 1. This decline coincides with a substantial increase in uncertainty. In this

${ }^{14}$ We do not include JP Morgan in Figure 1 because they provided basic disclosures already before 2007. We also performed checks for other major and potentially confounding news events on the bank-days relevant for Figures 1 and 2. We eliminate such events in robustness checks and conclude that they do not materially affect our findings and interpretations. See Online Appendix for further details. 
environment, characterized by massive uncertainty and declining bank valuations, disclosures could trigger negative market reactions, accelerate the decline in share prices, or worse, trigger bank runs as well as spillovers to other banks. Spillovers can occur because the market expects other banks to hold similar assets and thus to have similar exposures.

The CDS spread reactions on the day of the respective disclosure event (or the next day) are not consistent with (strong) adverse market reactions to banks' disclosures of risk exposures and losses (Figure 1, Panel A). For a few banks (especially Bear Stearns and Lehman), CDS spreads decrease when the market learns about the exposures and corresponding losses. For the other banks, we do not find any meaningful reaction. In Figure 1, Panel B, we plot CDS spreads centered on October 5, which is when Merrill Lynch and Washington Mutual were the first major U.S. banks to report negative information (i.e., losses) about their subprime investments. We see that CDS spreads for all 10 banks behave similarly and largely move in parallel. More importantly, market reactions to banks' disclosures are fairly moderate. In fact, we observe larger spread reactions on other days when there are no specific bank disclosures. For example, there is a substantial spike in all banks' CDS spreads in the middle of October 2007 (October 16, 17, and 19). This spike falls between October 5, when Merrill first reported its write-downs, and October 24, when it provided detailed information about its exposures to subprime mortgage-related securities. There is another large spike in the spreads for all banks on October 30, 2007, when Merrill Lynch reported the ousting of its CEO. Another example is the publication of the SEC's letter to Lehman, expressing concerns about a lack of adequate risk disclosures. In the days following its release on August 1, 2007, the CDS spreads for many sample banks increased considerably (Figure 2). 
To provide a more formal analysis, we regress daily changes in CDS spreads and stock returns on indicator variables for the 3-day window $[-1,+1]$ around (1) any disclosure event that reveals information about a bank's exposure to subprime (Bank Disclosure), (2) the first disclosure event for each bank (First Bank Disclosure), and (3) the first 10-Q or 10-K filing of each bank that includes information about its subprime exposures (First 10Q/10K Disclosure). In addition, we benchmark market responses to banks' disclosures against market reactions to other major events in the early phase of the crisis and include a series of 19 economic events that we selected based on the crisis time line based on a news search. We estimate the models using bank-fixed effects. ${ }^{15}$

Table 2 presents the results of the OLS regressions. The first significant CDS reaction to the market-wide events occurs when Federal Reserve chairman Ben Bernanke warned that the crisis in the U.S. sub-prime lending market could cost up to $\$ 100$ billion on July 20,2007 , and again when Countrywide Financial Corporation warned of "difficult conditions" on July 24, 2007. More such reactions follow later in the year (e.g., around the American Home Mortgage Investment Corporation (AHMI) bankruptcy on August 9 or when Freddie Mac announces major losses on December 2). The picture for the stock market returns is similar, except that there are a few significant reactions to the market-wide events already in the first half of 2007 (i.e., when Freddie Mac first reported problems on February 27).

In contrast to the significant market responses to major crisis-related events, the average reaction to bank disclosures about subprime exposures is negligible and statistically insignificant, including to their first of such disclosures. Thus, the regression analysis corroborates our

15 The results for the disclosure variables of interest are very similar and, if anything, stronger when we also add day fixed effects that essentially market-adjust the analysis (but absorb the individual economic event dummies). For robustness, we also include day fixed effects in Figure 1, Panel A, and plot the residuals from regressing daily CDS spreads on day fixed effects. The resulting plots look very similar and do not change the interpretation, i.e., there is little evidence for adverse reactions to the individual disclosure events. 
interpretation of Figure 1. We find significant market reactions to banks' first 10-Q and 10-K filings with information about their subprime exposures. As discussed in the previous section, these filings often adjusted previously disclosed subprime exposures and losses upwards. Thus, the negative market reactions are not surprising and could also reflect that the market was losing confidence in banks' reporting.

\subsection{Interpretation: Disclosures, information asymmetry, and investor confidence}

Gorton (2008) argues that there was an information problem at the heart of the panic of 2007 and Calomiris (2008) points to the role of information asymmetry. While the large drop in the ABX index made the problems in the subprime market apparent to market participants, they did not know how the risks were distributed throughout the economy, creating massive uncertainty as well as information asymmetries among market participants. Stock prices of financial institutions reflected this general concern. Our evidence on the evolution on banks' disclosures shows that they came late and market reactions to them suggest that the disclosures did little to reduce uncertainty and information asymmetries. There are several potential explanations for why disclosures emerged slowly and were ineffective.

One potential explanation is that the nature of the exposures and the severity of the crisis was initially not well understood. ${ }^{16}$ Moreover, banks' information evolved over time, which would also explain why disclosures were often revised and updated as the crisis unfolded. One example is the evolution of counterparty risk. For example, Merrill Lynch initially reported net exposures, but then switched to gross exposures when its hedges became ineffective due to increased counterparty

${ }^{16}$ Desai et al. (2015) find that rating agencies and analysts did not respond to initial signs of bank problems. In contrast, short sellers responded to early warning signs. Thus, their evidence suggests that some market participants reacted early, while others were slow to react, either because they underestimated the problems or had differential incentives. Indeed, sell-side analysts did not respond until March 2008, despite major declines in bank shares. 
risk and hence the positions could no longer be netted. ${ }^{17}$ Another example are downgrades of AAA-rated tranches of securitized subprime loans and mortgages. These securities were initially considered to be very safe but then experienced large price decreases and many were downgraded over the course of the crisis (e.g., Benmelech and Dlugosz, 2009; Ashcraft et al., 2011; He et al., 2011). A third example are banks' exposures from Structured Investment Vehicles (SIVs). These vehicles were structured to be off balance sheet, arguably because banks should have had limited or no exposures to them, but often these SIVs did not involve a real risk transfer and banks ended up bearing losses from conduits in the crisis (Acharya et al., 2013). Examples such as these could explain why banks initially claimed that they were "not exposed" or "well protected."

Still, if new information or changing exposures were the underlying reasons for the revisions of the initial disclosures, it is surprising that banks did not provide more detailed explanations. Moreover, even if matters got worse during the crisis, this evolution cannot explain why banks did not provide at least some basic information earlier. Given the crisis events until the middle of 2007, it is unlikely that banks thought that information about subprime exposures was unimportant or not of interest to investors. Admittedly, valuing subprime-related securities was very difficult during the crisis (e.g., Gorton, 2008), but banks could have disclosed more basic information (e.g., nominal (net) exposures to relevant assets and the types of securities they held at that time). Thus, we do not think that evolution of information early on in the crisis can explain why even basic disclosures about subprime exposures came so late.

Another explanation for why disclosures came relatively late is that banks were reluctant to be more forthcoming with detailed information because they feared adverse market reactions,

${ }^{17}$ Netting of assets and liabilities is an issue that has received greater attention only recently (e.g., Acharya and Ryan, 2016). 
including bank runs (e.g., Goldstein and Sapra, 2014; Bouvard et al., 2015; Goldstein and Leitner, 2018). The concern about triggering a run is particularly relevant for banks that rely heavily on short-term funding, which could dampen their disclosure incentives. In fact, banks could even have incentives to reassure investors (to counter concerns about bank losses or solvency that pre-existed in the market). Similarly, bank regulators may have feared contagion and spillover effects from bank disclosures, which in turn may have made them more lenient in their enforcement of existing disclosure requirements.

Against this backdrop, it is interesting that our market reaction analysis provides little evidence suggesting that investors overreacted to the disclosures when they came or that specific disclosures about subprime exposures or losses led to major spikes or negative market reactions for the banks. Instead, CDS spreads were often already substantially elevated before banks released their disclosures. The observed patterns suggest that either banks did not disclose relevant material information, or investors and analysts formed expectations about banks' problems and losses ahead of their disclosures, using many other sources. If anything, banks' early disclosures seemed to have (temporarily) assuaged investors' concerns. Although reassuring disclosures may provide temporary relief to banks, their long-run effect on financial stability is less clear, especially if later on, banks have to revise them, revealing larger exposures and losses. At that point, the market may lose trust in banks' reports and disclosures.

The run on Bear Stearns is an illustrative example in this regard. There are several indications that the unwillingness of institutional debt holders and counterparties to further provide Bear Stearns with sufficient liquidity was related to a loss of confidence in the bank (e.g., Wall Street Journal, 2008). This loss in confidence did not occur overnight, but was most likely a combination of worries about the bank's bad investments, which started with the collapse of two of its hedge 
funds in June 2007, management's struggles to present a convincing strategy how to deal with its problems, and a disclosure policy that downplayed the problems. For example, Bear Stearns' initial write-down of mortgage securities came later than the write-downs of its competitors, which might have (falsely) suggested that Bear was less exposed to the subprime market than its competitors. Investors later learned that this was not true. And even when Bear Stearns finally disclosed its subprime mortgage exposure, it provided fewer details than its peers. ${ }^{18}$

Another example for how trust in banks' reporting might have deteriorated during the crisis are Lehman's Repo 105 transactions, which briefly reduced its leverage right at the balance sheet dates. Even if these transactions did not violate GAAP, their intention was likely to conceal the bank's true leverage (e.g., Valukas, 2010; DeFond et al., 2018). If (at least some) market participants know about such practices and believe they are common for certain banks, it can trigger broader concerns about the reliability of these banks' reporting and, more importantly, raise concerns about the reporting of other banks, which may have been entirely forthcoming. While the Repo 105 transactions are a relatively stark example, it is by far not the only case. ${ }^{19}$

Underscoring the concerns about the reliability of reporting, many banks quickly faced securities litigation. For all but two of the 20 sample banks in Table 1 (BNP Paribas and Goldman Sachs), we find litigation cases related to financial reporting and disclosure filed by investors against the banks or their executives. For example, a class action lawsuit filed in October 2007

${ }^{18}$ For example, Bear Stearns disclosed only aggregate gross exposures for different asset classes in its initial November 14 filing, while its competitors (e.g., Merrill Lynch) had already started to provide granular information on the accounting valuation of these different assets (especially those with Level 3 fair values).

19 The SEC investigation of Fannie Mae and Freddie Mac (as summarized in "The Statements of Facts") reveals that both institutions were downplaying their subprime exposures in their disclosures. For example, Freddie Mac explicitly stated in its financial report that there is no universally accepted definition of "subprime," but then went on to provide an amount for its subprime exposure without giving a definition. It is hard to see how such a disclosure could be informative or engender trust with investors. Moreover, as became clear later, the amount disclosed in the financial statements did not include exposures that Freddie Mac internally considered to be subprime related. 
claimed that Merrill Lynch issued materially false and misleading statements that inflated Merrill's share price. The complaint suggested that top officers of Merrill benefitted from the false statements "as their compensation was based in large measure on Merrill's reported financial results. ${ }^{20}$ Similarly, in March 2008, investors filed a lawsuit alleging that Bear Stearns issued materially false and misleading statements. On June 19, 2008, the SEC charged two former portfolio managers of Bear Stearns Asset Management for fraudulently misleading investors about the financial state of the bank's two largest hedge funds and their exposure to subprime-backed securities before the collapse of the funds in June $2007 .{ }^{21}$ Of course, such lawsuits can have ulterior motives and hence their mere existence does not prove that banks' reporting was indeed misleading or that the defendants were guilty. ${ }^{22}$ But regardless of their merits, the lawsuits illustrate (and can contribute to) the concerns about banks' disclosures and financial reports.

\subsection{Implications: The importance of reliable (and structured) disclosures}

The important takeaway from our analysis is that bank disclosures about crisis-related exposures came late and when they came, they often had to be revised significantly, sometimes within weeks, without clear guidance as to what triggered the revision or what the disclosed "exposures" really meant. Based on our evidence, the market did not respond in a way that suggests the disclosures contained substantial information that was new to the market. Thus, it is unlikely that the disclosures themselves were a problem or made matters worse for the banks. At the same

20 The lawsuit was settled in August 2009 for an amount of million $\$ 475$. For an overview of the lawsuit and the filed complaint, see Shareholders Foundation (http://shareholdersfoundation.com/case/merrill-lynch-co-inc-nyse-merinvestor-securities-class-action-lawsuit-10302007). For quote see Class Action File, page 2.

21 See Stanford Law School, Securities Class Action Clearing House (http://securities.stanford.edu/filingscase.html?id=103954) and U.S. Securities and Exchange Commission, Litigation Release No. 20625, June 19, 2008 (https://www.sec.gov/litigation/litreleases/2008/lr20625.htm).

22 The two portfolio managers of Bear Stearns Asset Management settled the SEC's charges in 2012, agreeing to pay $\$ 1.05$ million in total, without admitting or denying the allegations. See U.S. Securities and Exchange Commission, Litigation Release No. 22398, June 25, 2012 (https://www.sec.gov/litigation/litreleases/2012/lr22398.htm). 
time, it is important to note that, based on our evidence, we cannot conclude that more forthcoming and earlier disclosures would have dampened the severity of the financial crisis. Our point is more modest, but still important. If we start from Gorton's (2008) and Calomiris' (2008) assessment that uncertainty and information asymmetries about banks' exposures were key problems, it is unlikely that suppressing disclosures is helpful. ${ }^{23}$ Timely and reliable disclosures are important for investor trust and frequent revisions to banks' disclosures can lead to an erosion of investor trust. Moreover, misleading disclosures at one bank can have contagion effects for the market's trust in other banks' disclosures, leading to negative externalities for healthy banks.

An obvious limitation of the market response analysis is that we do not observe the counterfactual. Market reactions to bank disclosures might have been very different and possibly stronger if the disclosures had come earlier. However, it is evident that markets do not "wait" for bank disclosures when a crisis unfolds. Moreover, when banks are highly levered with short-term funding, any negative piece of news could trigger a run or lead to coordination failures. In this precarious situation, it is not clear that withholding financial information (e.g., about exposures) could prevent a run and hence is a good reason to limit disclosures. Banks' disclosures are clearly not the only source of information market participants use to learn about the problems of financial markets or particular banks. The time series of stock prices and CDS spreads (which reflect market expectations over the crisis) as well as publicly available assessments of bank exposures by analysts and sophisticated investors at the time all illustrate that concerns about banks and their exposures arose well ahead and independently of banks' own disclosures. ${ }^{24}$

${ }^{23}$ In fact, evidence from the National Banking era in Granja (2018) suggests that public disclosures can reduce the risk of bank failures and increase financial stability, remarkably at a time, when banks were not protected against adverse reactions to negative information by explicit government guarantees.

24 A prominent example is the public interaction between Lehman and Greenlight Capital's hedge fund manager David Einhorn. In several speeches at analyst and research conferences, Einhorn analyzed Lehman's impairment policies for its subprime portfolios and largely justified his decision to short Lehman stock with his assessment that 
Consistent with our interpretation that the problem during the crisis was not 'too much' bankspecific information, but instead a lack of reliable disclosures, investors welcomed regulatory initiatives during the crisis (e.g., stress tests) that enhanced transparency. In response to the stress tests, banks (or the supervisors) published templates with standardized information about banks' assets and nominal exposures to particular asset categories. These rosters of assets enabled investors and analysts to build their own estimates for the values of banks' assets (see, e.g., Citigroup analyst report; Horowitz et al., 2009). That is, analysts often used the disclosed nominal exposures (principal amounts) in combination with default probabilities and loss-given-default estimates that they had developed on their own for various asset classes. Once they had estimates for banks' assets they could determine which banks were solvent and which ones needed extra capital. This example illustrates that relatively basic, yet structured, disclosures about nominal exposures to particular asset classes, like the ones that regulators in both Europe and the U.S. demanded as part of their stress tests, can be very useful to market participants (even in the middle of a crisis; e.g., Bischof and Daske, 2013). ${ }^{25}$ However, we recognize that information can be useful to market participants, yet not improve financial stability. But as noted before, it is very plausible that, in the absence of disclosures, market participants would seek such information regardless, potentially leading to rumors and exacerbating information asymmetries and adverse selection

\footnotetext{
its impairments were inadequate, when compared to expectations Einhorn formed based on publicly available data. For example, Einhorn stated: "Lehman has additional large exposures to Alt-A mortgages, CMBS and below investment grade corporate debt. Our analysis of market transactions and how debt indices performed in the February quarter would suggest Lehman could have taken many billions more in write-down than it did" (April 8, 2008, Grant's Spring Investment Conference).

${ }^{25}$ Here are two statements to illustrate the point that distinguishing different types of banks is important for market participants: "With the stress test and the extra information coming from it, we believe the market is beginning to be at a position to differentiate good and bad banks even if they are all in the same country with economic difficulties" (Société Générale, Report on Santander, 7/29/2009). "On the more positive side, the disclosure plans do look impressive this year, with the EBA disclosure template providing much more information than the 2010 equivalent. This should lead to better identification of which banks are actually at risk on the sovereign issue" (Deutsche Bank, Report on BNP Paribas, 7/8/2011).
} 
problems.

\section{Loan loss reporting: Recognition, disclosures, and incentives}

The rules for loan loss provisioning and recognition received considerable attention during and after the crisis. ${ }^{26}$ Banks' loan loss recognition was frequently criticized as being too small and coming too late, and the prevailing accounting rules were seen as a key reason for this "too-littletoo-late" problem (e.g., Dugan, 2009; Financial Stability Forum 2009; Barth and Landsman, 2010; Basel Committee on Banking Supervision, 2011, 2015; Curry, 2013). In response to this criticism, the FASB and the IASB changed the accounting rules for loans from an incurred loss model to a more forward-looking "expected credit loss model" arguing the new approach increases financial stability and reduces procyclicality (e.g., FASB, 2016; European Commission, 2016). While the rules have already changed, we still lack evidence on several key questions. How timely were banks in their loss recognition during the crisis? To the extent that banks were indeed late, what was the role of the accounting rules relative to banks' incentives to delay the reporting of losses? Understanding these questions is important, not only because loans are by far the largest asset category on banks' balance sheets, but also because the new accounting rules for loans likely provide more reporting discretion to banks going forward.

In this section, we investigate banks' loss recognition in reported loan book values (including provisions and impairments) and related loan loss disclosures. As in Section 2, a key challenge is the appropriate benchmark against which to assess the level and timeliness of banks' loss recognition. We benchmark banks' loan loss provisioning and write-downs against concurrent market estimates of future loan losses. This benchmarking exercise provides evidence on the level

${ }^{26}$ For instance, the Financial Stability Forum (2009) identified the regulation of loan loss provisioning as an important policy priority to reestablish financial stability. See also Bernanke (2009) and G20 Summit Declaration (2009). 
of banks' loss recognition at the height of the crisis. We also estimate banks' realized losses. While realized losses obviously have the benefit of hindsight and reflect endogenous crisis responses, they are still a useful reference point.

We recognize that there can be several reasons for why banks delay the recognition of loan losses, relative to market expectations. One reason is that the prevailing impairment rules may have constrained banks in their loss recognition. However, these rules did not constrain banks' disclosures of expected loan losses (in other places or forms). Thus, banks' loan loss disclosures should be informative about banks' reporting incentives. The idea is that banks that were constrained by the recognition rules but wanted to convey (additional) expected losses to investors could do so via disclosures. The disclosure analysis sheds light on banks' incentives to communicate future loan losses. However, the analysis does not answer whether banks could have chosen a higher level of impairments under the incurred loss model, as it is impossible to know from the outside to what extent the losses were incurred under the prevailing rules at the time.

To shed light on how banks applied the recognition rules, we analyze results of the ECB's Asset Quality Review (AQR). In this review, the ECB specifically evaluated whether European banks had sufficiently impaired their loan portfolios under the prevailing accounting rules (using its privileged access to bank loan data as a supervisor). Thus, AQR adjustments are a direct measure for the extent to which European banks' reporting of loan losses was constrained by the rules. To explore the possible role of incentives in the overvaluation of banks' loans, we investigate the association between $\mathrm{AQR}$ adjustments and banks' regulatory capital ratios. 


\subsection{Banks' loan loss recognition}

We examine the loan loss recognition for a sample of 237 listed U.S. bank holding companies. We derive this sample from the universe of FR Y-9C filings provided by the Federal Reserve Bank of Chicago. In 2008, there are filings for 306 listed banks. We merge these FR Y-9C filings with data from S\&P Global Market Intelligence on banks' FV disclosures for their loan portfolios, which banks report in their 10-K filings with the SEC. The merge leaves us with 263 banks with non-missing information. We have to exclude an additional 26 observations because certain financial data required for our regression analysis are missing, resulting in 237 observations.

We analyze banks’ 2008 financial statements, which were prepared and released early in 2009. At that point in the crisis, it was apparent that banks would sustain substantial loan losses. Moreover, after the government bailout and guarantees for U.S. banks in 2008, banks were likely less concerned about setting off runs and hence more willing to recognize loan losses. We compare banks' recognized loan losses to market estimates for banks' expected loan losses derived early in 2009. Specifically, we create a proxy for concurrent market expectations using (1) loan loss estimates for specific banks from the SCAP stress test and a Citigroup analyst report and (2) forecasted loss rates for different classes of loans provided in analyst reports by Goldman Sachs and Standard \& Poor's. The reports were prepared between February 26 and May 7, 2009 (see Table 3 for details). For 15 large banks, we have at least one bank-specific loan loss estimate (Table 3, Panel A). For all other banks, we derive market estimates for expected loan losses by multiplying the forecasted loss rates for the different loan categories in the Goldman Sachs and Standard \& Poor's reports with banks' loan holdings in the respective categories (as reported in FR Y-9C filings in Q4 2008). This approach is admittedly coarse as it assumes that banks have 
similar loss rates in each loan category, but it does consider differences in the composition of banks' loan portfolios and allows us to expand the sample beyond the 15 banks in Panel A.

In addition, we estimate realized loan losses from the loan portfolio that U.S. banks held in 2008 by accumulating net charge-offs from 2009 to 2010 and to 2011 . The three-year period likely captures a majority of realized loan losses from these loan portfolios. It also provides a reasonable trade-off between (i) including charge-offs from loans originated after 2008 and (ii) not including loan defaults from the 2008 loan portfolio that were realized after 2011 (or 2010). We do not benchmark banks' loan loss reserves against future charge-offs because realized losses can obviously deviate from expected losses, not the least because policy interventions during the crisis could affect future charge-offs. We simply use charge-offs as a reference point that puts the magnitude of our market-based loss estimates into perspective. Such a reference point is useful as one might be concerned that market estimates at the height of a crisis could be exaggerated. Of course, this comparison does not validate the market expectations.

We begin our analysis with the 15 large banks, for which we have at least one bank-specific loss estimate. In Table 3, Panel A, Column C, we tabulate banks' allowances for loan losses. The allowance is a reserve that accumulates provisions for future loan losses that are not yet realized (or charged off). Next, we benchmark the reported reserves against concurrent market estimates of future loan losses. For the latter, we use bank-specific loan loss estimates whenever available (Columns E and F) as well as estimates derived from the forecasted loss rates for different loan categories applied to banks' loan portfolios (Columns $\mathrm{G}$ and $\mathrm{H}$ ). We compute the median estimate across these estimates (Column I) and also the ratio of this median and the allowance (Column J). We see that banks' reported allowances are substantially below concurrent market expectations. Specifically, the ratio of expected loan losses based on market estimates to recognized future loan 
losses in the allowances varies between 1.51 (First Horizon) and 4.16 (BB\&T Bank). For the median bank, market loss estimates exceed recognized loss estimates (i.e., allowances) by a factor of 3.05, which is quite substantial. ${ }^{27}$ This result carries over to the full sample of 237 banks; here, market expectations exceed recognized losses by an average (median) factor of 5.18 (5.08).

In Columns $\mathrm{M}$ and $\mathrm{N}$, we report the cumulative net charge-offs of the 15 sample banks over the next two and three years, respectively. In Column $\mathrm{O}$, we find that the market estimates for most banks are relatively close to the cumulative realized losses over the next three years. Accordingly, the median (average) ratio of market estimates to future charge-offs is 1.09 (1.25). Thus, market expectations for banks' loan losses in early 2009 turned out to be largely in line with the loan losses that banks subsequently realized. This further supports the evidence in Column J suggesting that banks' loan loss allowances were low and that their loss recognition came late. ${ }^{28}$

An important question is why banks' recognition of loan losses at the end of 2008 was late (or so low). One explanation is that banks were constrained by the recognition rules for loan losses. For example, FAS 5 in U.S. GAAP requires incurred losses to be probable and estimable, which could restrict banks' ability to record expected credit losses that do not meet the "probable" or "estimable" thresholds. ${ }^{29}$ The standard's explicit reference to impairments or losses that are incurred because of events take took place prior to the fiscal year end is widely interpreted as restricting banks' ability to include losses due to future events when setting their provisions. This restriction, which commonly is called the incurred loss model, could be particularly relevant early in a downturn, making it harder for banks to recognize future losses that are already on the horizon.

27 These findings are consistent with a similar analysis for the four largest banks in Laux and Leuz (2010).

${ }^{28}$ This evidence is consistent with Vyas (2011) and Huizinga and Laeven (2012). While banks may have delayed their loan loss recognition and overvalued assets, Calomiris and Nissim (2014) point to economic and regulatory changes that could also explain why banks' market-to-book ratios decreased during and after the crisis.

${ }^{29}$ The probable threshold was defined as "likely to occur" and typically interpreted as being higher than $50 \%$. See EITF D-80, Ryan and Keeley (2013), Wall (2013). 
Based on these arguments, the Financial Crisis Advisory Group to the FASB and the IASB identified credit loss recognition as a major weakness in the accounting rules and as a source of procyclicality (FCAG, 2009). For this reason, both standard setters adopted the expected credit loss model, which requires more forward-looking provisioning for future loan losses.

An alternative explanation for the delay in loss recognition in 2008 is that banks have various reasons to be reluctant to recognize loan losses (e.g., to manage earnings or preserve regulatory capital). Loan accounting, like any other accounting rule, provides substantial discretion to banks, which the latter can exploit to avoid the recognition of losses. Hence, banks' reporting incentives could play an important role for their loan loss recognition. ${ }^{30}$ In the next section, we gauge the role of incentives by studying banks' loan loss disclosures.

\subsection{Banks' loan loss disclosures}

While the incurred loss model could have constrained banks' loan loss recognition, it does not apply in the same way to loan loss disclosures. Thus, we can compare banks' loan loss disclosures to market expectations about their loan losses to learn about banks' willingness to communicate expected loan losses. For U.S. banks, two types of disclosures are particularly relevant. We consider each type in turn.

Forward-looking loan loss disclosures in 8-K filings

Regulation S-K in the U.S. requires all SEC registrants to report material adverse events on a current basis using Form 8-K. Thus, if the crisis events in 2007 and 2008 led banks to expect material future loan losses that were not already recognized in their financials, Regulation S-K

${ }^{30}$ Consistent with our argument and the existence of discretion, there is substantial cross sectional-variation in the timeliness of loan loss provisions (e.g., Beatty and Liao, 2011; Bushman and Williams, 2015; and Gallemore, 2018). There is also an extensive literature on the role of reporting incentives in accounting more generally, which provides a conceptual basis for our discussion here. See, e.g., Ball et al. (2003), Leuz (2003), Burgstahler et al. (2006). 
gives rise to a disclosure obligation. In addition, FAS 5 (which stipulated the incurred loss model) required banks to disclose additional loan losses that do not meet the recognition criteria, unless the probability of such losses given past or current events was only "remote." Thus, the probability threshold in FAS 5 for disclosure was substantially lower than for recognition. If the crisis events meant that future losses were more than a remote chance, banks had a disclosure obligation under FAS 5, even if the losses did not meet the recognition criteria. Given these rules, 8-K filings are a natural place for banks to provide such forward-looking loan loss disclosures.

We search all 8-K filings by U.S. financial institutions between January 1, 2007 and December 31, 2008 for loan loss disclosures in Item 2.06, Item 4.02, Item 7.01, or Item 8.01 (based on the SEC's 8-K Guidance). We distinguish between loan loss disclosures that pertain to recognized losses in the same or a previous quarter and forward-looking disclosures that precede a formal loss recognition. The former could be profit warnings or pre-announcements for the upcoming financial report (10-Q or 10-K). In the latter case, banks essentially disclose loan losses that are expected but do not yet meet the criteria for recognition in the accounting rules. These forward-looking disclosures are the focus of our analysis.

Figure 3 summarizes our findings. The solid gray line plots the number of $8-\mathrm{K}$ filings issued between 2007-Q1 and 2008-Q4 that are related to material loan losses. The dotted black line shows the number of 8-K filings with forward-looking loan loss disclosures (i.e., losses that are not also recognized). In total, we have 123 filings related to loan losses. We find only 30 8-Ks from 23 banks (18 reports in 2007 and 12 reports in the first two quarters of 2008) with forward-looking loan loss disclosures. ${ }^{31}$ Our search covers 911 distinct financial institutions that are SEC registrants

${ }^{31}$ Four of these disclosures come from three banks in Table 3, Panel A: KeyCorp (2007Q4, 2008Q1), SunTrust Banks (2007Q4), PNC Financial (2007Q4). KeyCorp's 8-K filing from February 19, 2008, states: "Changes in market conditions, including most significantly the widening of credit spreads, can adversely affect the market values of 
and hence could be filing an $8-\mathrm{K}$. Thus, only $2.5 \%$ of the banks provide forward-looking disclosures. Most of the loan loss disclosures in 8-Ks pertain to loan losses or impairments that are also recognized in the financial statements in the respective quarter (just like Merrill Lynch's disclosure on October 5, 2007).These disclosed loan losses met the conditions for recognition (i.e., were incurred). Beyond those, very few banks provide forward-looking disclosures with (additional) future credit losses. It is noteworthy that we find none in Q3 and Q4 2008, considering that by the end of 2008, it was clear that banks would sustain major credit losses in the coming years. In fact, as Table 3, Panel A shows, market estimates far exceeded banks' loss recognition. Assuming that these market estimates were reasonable, we would expect to see many forwardlooking disclosures, informing investors about impending future loan losses. The fact that we see few of these disclosures suggests that banks were reluctant to reveal expected losses to the market and suggests that reporting incentives could have played an important role for banks' loan loss recognition as well. ${ }^{32}$

\section{FV disclosures for loans}

Even though loans are typically reported at amortized costs, U.S. GAAP requires banks to disclose the FV of their loans in the notes to the financial statements (FAS 107). Thus, a second way for banks to communicate expected loan losses to investors is via the FV of their loan portfolios. Conceptually, expected future credit losses reduce the FV of a loan. Thus, if banks expect losses on their loans beyond those that are recognized in the net book value, they should

Key's loan and securities portfolios held for sale or trading, resulting in the recognition of both realized and unrealized losses. If market conditions at March 31, 2008, are similar to those experienced as of February 13, Key would expect to record additional adjustments of approximately $\$ 65$ million after tax." See also Table 3, Panel B.

32 The cross-sectional variation in banks' loss recognition illustrated in Table 3 is consistent with banks exercising substantial discretion in the application of the accounting rules. Similarly, Bierey and Schmidt (2017) document that impairments on Greek government bonds vary substantially across European banks even when the underlying instrument is the same, again consistent with banks using substantial discretion. 
include them in the loan FVs. In addition, loan FVs reflect interest rate changes since loan origination, and the Federal Reserve lowered interest rates during the crisis, which counteracts the FV decline due to credit losses. However, loans are illiquid and, as the crisis has shown, involve a systemic risk component. It is therefore also relevant that yield spreads between illiquid risky securities and liquid risk-free securities widened during the crisis. For many loan portfolios, it seems plausible that the latter effect dominated the decrease in the risk-free rate, suggesting that the discount rate for loans increased during the crisis. If banks used such rates in determining the disclosed $\mathrm{FV}$, then the disclosed loan FVs include illiquidity premia and hence overestimate expected credit losses.

With these caveats in mind, we compute the difference between the book value of the loans (net of the allowance for loan losses) and the corresponding FV of the loans (disclosed in the notes) as a proxy for additional loan losses that banks expect beyond those recognized in the allowance. In Table 3, we add the difference between Column A and B to the allowance for loan losses to obtain an estimate for the total losses that are implied by the FV and the allowance. ${ }^{33}$ We show this total implied loss in Column D and compare it to the concurrent market estimates for the loan losses. We compute the ratio between the (median) market estimate and the total implied loss reported by banks and then compute the average and the median of these ratios (Column K). The median (mean) ratio is $1.33(1.27)$ and hence substantially lower than the corresponding ratio in Column J using just the allowance. For the average or median bank, the market estimate still exceeds the total implied loss reported in the financials by about $30 \%$. However, the substantial

${ }^{33}$ To illustrate, Capital One reports a FV for the loan portfolio of $\$ 86.4$ billion, which is $\$ 10.1$ billion below the reported book value (net of the allowance). Adding this difference to the allowance of $\$ 4.5$ billion, we obtain the total implied loss of $\$ 14.6$ billion that the bank reports for its loan portfolio. 
decline in the ratio implies that banks used the FV disclosures for the loan portfolio to reveal additional losses that they expected but did not recognize in the loss allowance.

Specifically, comparing the total implied loss (Column D) and the market estimate (Column I), there are six banks, for which the FV implies larger losses than the current market estimate. For instance, Capital One reports a total implied loss of $\$ 14.6$ billion, which far exceeds the allowance ( $\$ 4.5$ billion) and is even larger than the median market estimate of $\$ 11.8$ billion. Thus, in this example, the bank communicated expected loan losses via the FV beyond what it recognized on the balance sheet, suggesting that some of these losses did not meet the criteria for recognition. Here, the incurred loss model could have been a constraint. However, for the median sample bank and especially for the four largest banks, the ratio in Column $\mathrm{K}$ is well above one, implying that the market expected substantially higher loan losses than what the banks recognized or disclosed.

Thus, the picture that emerges for the FV disclosures is quite similar to the one for $8-\mathrm{K}$ disclosures. Even early in 2009 when the market expected substantial future loan losses, banks were reluctant to communicate this possibility through additional disclosures. We acknowledge that FV disclosures for loans likely face less scrutiny than recognized balance sheet numbers and hence may be of lower quality (e.g., Cantrell et al., 2014). But if this difference in scrutiny explains banks' loss disclosures, it only underscores the role of banks' reporting incentives.

To explore more formally the role of banks' reporting incentives, we analyze the associations between recognized loan loss allowances and the concurrent market estimates as well as banks' capital ratios. Separately, we study the associations for disclosed loan losses implied by the FVs in the notes. That is, we regress recognized and disclosed loan losses on market estimates and the regulatory capital constraints, controlling for bank and loan portfolio fundamentals. We present the results in Table 3, Panel B. We now expand the sample from Panel A and include all publicly- 
listed U.S. bank holding companies, for which we have the necessary data from their FR Y-9C filings. As we do not have bank-specific loan loss estimates (as in Panel A) for the vast majority of these banks, we use the forecasted loss rates for various loan categories in the Goldman Sachs and the S\&P reports together with the loan portfolio composition of each bank. The final sample comprises 237 banks.

The analysis in Panel B, Columns (1) to (6) shows that banks' loan loss allowances exhibit significantly positive associations with both expected future loan losses as well as future realized losses (or charge-offs). These associations are robust to controlling for bank fundamentals and the composition of banks' loan portfolios (Column 3). As our earlier analysis in Panel A suggests that banks' loss recognition in 2008 was late (or relatively low), we explore to what extent the level of banks' loss recognition is related to their regulatory capital constraints and corresponding incentives. We introduce two binary variables (Low Capital Ratio and Low Tier 1 Ratio) indicating whether the respective capital ratio is in the lowest quartile of our sample. Consistent with the idea that banks that are close to their capital constraints are more reluctant to recognize losses, we find significantly negative associations for the low-capital indicators and the reported allowances. ${ }^{34}$

In contrast, the evidence for losses that banks disclose via their loan FVs is quite different. There is essentially no association between the market's loss estimates and banks' disclosed FV losses, and the association with future realized losses is insignificant as well. Thus, on average, banks do not use FVs for loans to disclose expected future loan losses, consistent with prior studies suggesting that the informativeness and enforcement of FV disclosures are relatively low (e.g., Nissim, 2003; Ahmed et al., 2006). That said, banks that provide forward-looking loan loss disclosures in 8-Ks also provide higher FV loss disclosures, as indicated by the significantly

34 This evidence is similar to the findings in Hanley et al. (2018) for FV estimates by insurance companies. 
positive indicator in Column (10). Thus, at least some banks used these channels to communicate expected loan losses beyond those that are already recognized. We do not find a significant relation between banks' capital constraints and disclosed FV losses. This finding is consistent with the fact that these FV losses have no effect on regulatory capital.

\subsection{Evidence on the use of discretion in loan loss estimates}

The above evidence from 8-K and FV disclosures supports the view that banks were reluctant to disclose expected loan losses. As such, the evidence is inconsistent with the notion that banks wanted to communicate larger losses than they could recognize under the prevailing accounting rules. It also casts doubt on the narrative that banks were constrained by the incurred loss model.

However, we acknowledge that it is difficult "from the outside" to assess whether losses were incurred under the prevailing accounting rules at the time. Thus, a low level of loan loss recognition relative to concurrent market expectations does not imply misreporting. Moreover, even when banks apply the accounting rules properly, they can use discretion in the rules to reduce the level of recognized losses. Such behavior would also be consistent with what we documented for banks' disclosures in Section 3.2. We do not have the data for U.S. banks to differentiate between these alternative interpretations. We therefore turn to the ECB's Asset Quality Review (AQR) for European banks, as it offers additional insights as to whether banks were constrained by the rules.

\section{The ECB's Asset Quality Review of European banks}

The ECB's AQR essentially entailed an independent assessment of banks' loan loss recognition and provisioning. The $\mathrm{AQR}$ was an important part of the so-called Comprehensive Assessment that the ECB conducted when it took over the supervision of the most significant EU banks. The objective of the assessment was to enhance the transparency of bank exposures and to 
assure that banks fulfilled the ECB thresholds set by its Pillar 2 capital requirements. The AQR investigated shortfalls in the banks' 2013 financial statements relative to these thresholds, making adjustments to banks' loan loss provisioning, FVs and for counterparty risk. National supervisors were responsible for ensuring that the AQR's guidelines were followed at the bank level. The ECB published the results of both the stress test and the AQR on October 26, 2014.

Importantly for our purposes, the AQR was based on "the relevant accounting principles" at the time, which means IAS 39 for IFRS-reporting banks (ECB, AQR Guidelines, p. 8-9). That is, adjustments do not reflect a stress scenario or additional regulatory buffers. As a result, we can interpret positive $\mathrm{AQR}$ adjustments to banks' loan provisions as instances in which banks overstated their loan portfolios according to the ECB's interpretation of the prevailing rules (including the incurred loss model). Thus, the level of AQR adjustments provides a way to gauge whether banks could have reported higher loan losses under extant accounting rules, and crosssectional variation in the adjustments could provide insights into specific reporting incentives for banks' loss recognition and the use of discretion in the extant rules.

We analyze the AQR results for all 130 participating banks. Table 4, Panel A provides evidence on the magnitude of the AQR adjustments to the loan loss provisions. The upper part of Panel A presents individual results for the 15 banks with the largest absolute adjustments; the lower part presents summary statistics for the full sample of 130 banks. We find that the AQR adjusted the loan loss provisions upwards for 112 banks. Thus, only 18 banks saw no adjustment at all. On average, and for the majority of banks, the adjustments were economically material relative to a number of benchmarks. Thus, this evidence implies that European banks' loan portfolios were overstated, relative to the ECB's interpretation of the existing rules. Moreover, the 
low levels of loss recognition cannot be fully explained with constraints in the accounting rules or the incurred loss model.

Next, we investigate the role of reporting incentives in explaining cross-sectional variation in banks' loss recognition. Towards this end, we regress AQR adjustments on various bank fundamentals, such as size, risk-weighted assets, leverage, and profitability. Our primary variable of interest is a proxy indicating that a bank is relatively close to its capital constraint (Low CET1 Ratio) and hence likely has incentives to preserve capital and reduce its loan loss provisions. In some specifications, we also control for a bank's corrective actions prior to the AQR (dividend cuts, RWA cuts, leverage cuts, and capital issuances). ${ }^{35}$ Out of the 130 banks that participated in the $\mathrm{AQR}$, we can retrieve the necessary data in BvD Bankscope for 74 or 76 banks depending on the specification.

We present the results in Table 4, Panel B. In Columns 1 to 3, we measure the AQR adjustment in basis points of regulatory capital. In Columns 4 to 6 , we measure the AQR adjustment relative to the total book value of the bank's assets. The results are similar across both models. Consistent with the notion that banks with low regulatory capital are more reluctant to recognize loan losses (see also Hanley et al., 2018, for insurance firms), we find that the indicator for low regulatory capital is positively and significantly associated with banks' AQR adjustments (i.e., the overvaluation of the loan portfolios). This evidence suggests that regulatory constraints are a source for banks' reporting incentives. Interestingly, corrective actions taken prior to the AQR are negatively associated with the AQR adjustments. That is, the banks with overvaluations are those

${ }^{35}$ See Table 4 for a definition of the variables and Section 4 for a detailed discussion of our measure of corrective actions. Results for the Low CET1 Ratio are similar, but weaker when we expand the indicator to banks below the median of the CET1 ratio or when we replace the indicator variable by a continuous measure (untabulated). 
with fewer corrective actions before the $\mathrm{AQR}$, which is what we expect to see if the ability to use accounting discretion weakens banks' incentives to engage in corrective actions.

\subsection{The importance of reporting incentives and enforcement}

Based on research to date, it is too early to say whether the expected loss model will make a difference when it comes to procyclicality and financial stability. ${ }^{36}$ However, our evidence for U.S. banks' loan loss reporting as well as the AQR for European banks clearly suggests that banks are reluctant to disclose or recognize losses. These incentives together with discretion in the rules essentially allow banks to delay the reporting of losses.

This evidence on banks' reporting incentives has important implications for the regulatory debate about the role of accounting for financial stability. First, it suggests that enforcement by securities regulators, bank supervisors and auditors deserves much more attention in the debate (see also Costello et al., 2019; Granja and Leuz, 2019). Second, it casts doubt that changing the accounting rules to an expected loss model alone will have the intended impact on financial stability. The evidence in this section suggests that banks are reluctant to recognize or disclose losses, whether they are incurred or expected. Thus, banks' reporting incentives and how they interact with the discretion in the rules is an important topic for future research (see also Behn et al., 2016a, 2016b).

To illustrate that these insights are important and relevant, we point out that the regulatory response after the crisis (as far as accounting is concerned) largely focused on the rules (or the loss

36 The evidence in Beatty and Liao (2011) and Bushman and Williams (2015) suggests that more timely recognition should matter. However, as Acharya and Ryan (2016) point out, these findings face a number of identification challenges and are far from settled. Jiménez et al. (2017) find that dynamic provisioning in Spain reduces the cyclicality of credit supply. See also Abad and Suarez (2018) and Chae et al. (2018), who simulate the effects of different provisioning models for credit losses on banks' profit and loss and regulatory capital. 
model in the rules), rather than on mechanisms that could change banks' reluctance to report losses and impairments of their assets. While the expected loss model shifts the recognition of loan losses to earlier periods, the forward-looking nature of the approach implies even more managerial judgment and discretion in the measurement of expected loan losses. Thus, given our evidence on banks' incentives to use discretion to delay the reporting of losses, we have little reason to believe that this tendency would be different when banks operate under an expected loss model. ${ }^{37}$ Moreover, loss provisioning based on expected losses will not provide banks with incentives to take corrective actions if regulators change the rules or become lenient in their enforcement once banks face problems. Thus, without stronger enforcement and a commitment on the part of the regulator, it is unlikely that the expected loss model will have the intended effects.

\section{Prudential filters and banks' corrective actions}

Capital regulation is a key channel through which accounting rules could affect bank behavior and hence financial stability. Book equity as determined by the accounting rules generally serves as the starting point when computing banks' regulatory capital. Loss recognition and provisioning as well as impairment rules determine banks' profits and equity and can have a direct effect on regulatory capital set by prudential regulation. Regulators can apply so-called prudential filters to counter this direct effect, by adjusting which accounting items enter the calculation of capital for regulatory purposes (e.g., exclude intangibles, deferred tax assets). A prominent example are unrealized gains and losses from AFS securities, which are recognized in Accumulated Other Comprehensive Income (AOCI), a separate component of a bank's book equity. Prudential regulators often add back unrealized FV losses from AFS debt securities in the computation of

37 The change in the rules and the expected loss model could matter in regulatory stress tests. As the simulations are based on the rules and conducted by the regulator, banks' reporting incentives play a smaller role. 
regulatory capital, which is commonly called an AOCI filter. ${ }^{38}$

The underlying rationale for shielding regulatory capital from FV losses is to prevent fire sales and downward spirals when the FV of AFS securities declines. At the same time, AOCI filters can reduce managers' incentives to take corrective actions in response to FV declines, especially early in or ahead of a crisis. ${ }^{39}$ For instance, with a filter, bank managers could feel less pressure to raise capital or to reduce dividend payments and risk exposures. Thus, an important question is: Do prudential filters dampen banks to take prompt corrective actions when they incur FV losses?

After the crisis, U.S. bank regulators planned to eliminate the AOCI filter in the process of adopting Basel III. But due to fierce opposition from banks, U.S. bank regulators eventually granted a one-time option to retain the filter for banks using a non-advanced approach in their calculation of risk-weights. Nearly all eligible U.S. banks chose this option (Kim et al. 2019). Thus, understanding the effects of AOCI filters continues to be of practical and regulatory importance. However, we have little evidence on how prudential filters affect corrective actions when banks incur FV losses.

In this section, we investigate the link between losses and banks' corrective actions. We exploit cross-sectional and time-series variation as well as within-country variation in prudential filters for FV losses from AFS securities to analyze the association between AFS losses and banks' corrective actions. While not the focus of our analysis, prudential filters can also affect banks' initial classification of securities and types of securities banks hold. Beatty (1995) and Hodder et

${ }^{38}$ U.S. regulators chose to apply the AOCI filter for the regulatory capital of U.S. bank holding companies. AOCI filters did not play a role for U.S. investment banks since they are not regulated under Basel regulatory standards. This changed during the crisis when investment banks such as Goldman Sachs and Merrill Lynch obtained bank holding company status in late 2008.

39 Moreover, if unrealized losses are excluded from regulatory capital, banks can also have incentives to avoid the sale of these securities and engage in opportunistic gains trading (e.g., Barth et al., 2017; Dong and Zhang, 2018). 
al. (2002) find evidence for strategic portfolio management by financial institutions around the introduction of SFAS 115 and AOCI filters in the U.S. in 1993-1995. Similarly, Hamilton (2018) and Kim el al. (2019) show that U.S. banks reclassify assets from AFS to Held-to-Maturity (HTM) after the removal of AOCI filters in 2014 and that the ensuing trading restrictions of the HTM classification can affect banks' asset portfolio and refinancing choices. ${ }^{40}$

Our analysis is similar in spirit to other banking studies documenting the effects of regulatory capital constraints (e.g., Aiyar et al., 2014a, 2014b), but focuses on banks' corrective actions (see also Ben-David et al., 2019), which are important for financial stability. Our analysis is also related to evidence for insurance companies, pointing to important interactions between accounting and prudential regulation. Merrill et al. (2014) and Ellul et al. (2015) show that U.S. property and casualty insurance companies, for which FV losses have more direct regulatory implications than for life insurance companies, are more likely to sell downgraded assets with price declines. In contrast, U.S. life insurers, which are subject to more historical cost accounting, exhibit more risk taking in the pre-crisis period (Ellul et al., 2014) and disproportionately engage in gains trading in the financial crisis (Ellul et al., 2015). ${ }^{41}$

\subsection{Institutional Setting}

IFRS and U.S. GAAP require banks to report FV gains and losses from AFS securities and to accumulate these gains and losses in the AOCI equity account. AOCI filters set by the prudential

${ }^{40}$ HTM securities, in contrast to AFS securities, are recognized at amortized cost. Chircop and Novotny-Farkas (2016) analyze market reactions around the announcement by U.S. regulators to adopt Basel III regulation and include unrealized FV gains and losses from AFS securities in regulatory capital. On average, market reactions are negative. However, this evidence is difficult to interpret in light of other concurrent events and considering that the effects for shareholders and tax payers can go in opposite directions.

${ }^{41}$ Interestingly, the evidence for life insurers is similar to the evidence for banks, for which AOCI filters generally shield capital from FV losses. Badertscher et al. (2012) and Abbassi et al. (2016) find little evidence of fire sales for European or U.S. banks and show that banks increase their securities holdings during the crisis. 
regulators determine the fraction of accumulated unrealized FV gains and losses that are excluded from regulatory capital. There are significant differences in AOCI filters for accumulated losses from AFS debt securities across countries (Bischof et al., 2019). Some countries adjusted these filters during the crisis. In addition, the application of the filters depends on the accounting standards banks follow for regulatory purposes (IFRS versus local GAAP).

We exploit this variation in AOCI filters to examine whether prudential filters affect the extent to which banks take corrective actions early in the financial crisis. Specifically, we analyze reductions in dividends, risk-weighted assets (RWA), and leverage, as well as raising new equity. Reducing dividends is an important way for banks to preserve capital. In fact, U.S. banks were criticized for delaying dividend cuts during the financial crisis (e.g., Acharya et al., 2011). In addition, banks can raise new equity, sell assets and repay debt to reduce leverage as well as reduce the risk of the assets they hold.

\subsection{Sample and data}

We start with the global universe of banks from 39 countries that have adopted IFRS for financial reporting and for which we have information on their prudential filters for AFS debt securities reported under IFRS (Bischof et al., 2019). BvD Bankscope includes 32,525 bank-years for 3,414 IFRS-reporting banks from these 39 countries for the period from 2001 to 2016 . To avoid double counting, we exclude 7,234 bank-years from 1,011 banks that are consolidated into the group accounts of another sample bank. We lose an additional 22,362 bank-years because of missing financial data to construct our variables. Our final sample comprises 2,929 bank-years and 740 distinct banks from 38 countries. We winsorize all variables at the $1 \%$ and $99 \%$ level. 
For our analyses, we distinguish between countries with a $100 \%$ filter for losses from AFS debt securities (17 countries) and countries with less extensive filters ( 15 countries with a $0 \%$ filter and two countries with a $55 \%$ filter). We identify four countries that changed their AOCI filters for losses from AFS debt securities during our sample period: Germany and Portugal in 2009, Italy and Spain in 2010. In all four cases, countries introduced a $100 \%$ filter. We ignore other prudential filters (e.g., for AFS equity securities or accumulated gains from AFS debt securities) because (1) equities represent a much smaller fraction of banks' assets and (2) there is much less variation in other filters across countries (e.g., very few countries exclude unrealized gains and losses from AFS equities from capital). In addition, five countries permit banks to use local GAAP for regulatory purposes, in which case FV losses in the IFRS financial statements are not relevant, generating within-country variation in filters if some banks use local GAAP for regulatory capital.

In Table 5, we provide descriptive statistics for the sample banks in countries with a $100 \%$ AOCI filter and in countries with less extensive filters in the pre-crisis year 2006. We note that there are systematic differences across these two groups. Banks in the group with a $100 \% \mathrm{AOCI}$ filter are larger, rely on more short-term funding, and are more weakly capitalized. Moreover, the fraction of AFS and trading securities is on average larger for banks that have a 100\% AOCI filter.

Comparing the volatility of capital ratios across filter groups is also interesting. Given the AOCI filters mechanically shield regulatory capital against the volatility of FV assets, one might expect regulatory capital ratios to exhibit larger volatility differences across the two filter groups than accounting equity (as the latter includes AOCI for both groups). However, the descriptive statistics are not consistent with this expectation or the notion that prudential filters reduce the volatility of capital ratios. Both bank groups exhibit comparable volatility of the accounting equity ratios (3.86 vs. 3.83$)$ and comparable volatility of the regulatory capital ratios (4.90 vs. 4.56 for 
tier 1 capital). This evidence is descriptive and needs to be interpreted cautiously because other factors (e.g., differences in bank characteristics) can influence the volatility of capital ratios. However, it does raise the question of whether the effects of filters on banks' risk taking outweigh their mechanical effects in reducing the volatility of capital ratios.

\subsection{Research Design}

The idea of our analysis is to examine whether prudential filters alter banks' corrective actions in response to AFS losses. Thus, we estimate the association between current corrective actions and lagged (or concurrent) AFS losses and then test whether this association differs depending on the filter regime. We estimate the following regression model:

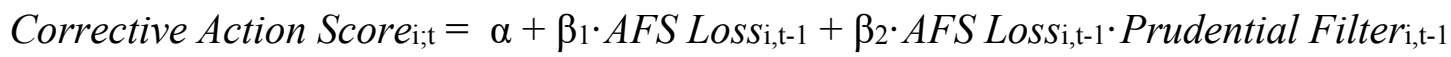

$$
\begin{aligned}
& +\beta_{3} \cdot \text { AFS LosSi,t }+\beta_{4} \cdot \text { AFS Loss } \mathrm{it}^{\cdot} \text { Prudential Filter } \mathrm{i}, \mathrm{t}-1 \\
& +\beta 5 \cdot \text { Prudential Filter } \mathrm{r}_{\mathrm{i}, \mathrm{-}-1}+\beta_{6} \text { Controls } \mathrm{i}, \mathrm{t}+\gamma_{\mathrm{i}}+\delta_{\mathrm{t}}+\varepsilon_{\mathrm{i}, \mathrm{t}}
\end{aligned}
$$

where $i$ denotes the individual bank and $t$ denotes the fiscal year. We define corrective actions as Dividend Cuts (if Dividend Payouts are lower than in the previous period), RWA Cuts (if RiskWeighted Assets are lower than in the previous period), Leverage Cuts (if Leverage is lower than in the previous period), and Capital Raising (if Share Capital is larger than in the previous period) and define binary indicators for them. ${ }^{42}$ The Corrective Action Score (\# Cuts) is the sum of the values of Dividend Cuts, RWA Cuts, Leverage Cuts, and Capital Raising, divided by 4. AFS Loss takes a value of 1 if the sum of realized and unrealized gains and losses from AFS securities in the respective year is negative, zero otherwise. ${ }^{43}$ Prudential Filter is a binary indicator that takes a

\footnotetext{
${ }^{42}$ See Table 6 for detailed definitions of all variables.

${ }^{43}$ It is important to consider that filters could influence banks' willingness to realize gains or losses. For example, banks with filters may be willing to realize losses, while banks without filters may strategically realize gains (via gains trading). By using the sum of realized and unrealized gains and losses, we measure gains and losses irrespective of (strategic) sales of securities, which should help to isolate the effect of filters.
} 
value of 1 if FV losses from AFS debt securities do not affect a bank's regulatory capital, either because capital regulation in a bank's domicile adds back $100 \%$ of the losses (AOCI filter) or regulatory capital is based on local GAAP, zero otherwise. We include bank and year fixed effects.

Although regulators set the filter at the country level, there is additional within-country variation that we exploit: over time (when the filters change) and in the cross-section (when certain banks do not use IFRS for regulatory purposes and AFS losses in their financial reporting under IFRS do not apply for capital regulation). The latter variation exploits differences between local GAAP and IFRS when it comes to FV losses and gains for securities, and enables us to also estimate models, in which we use country-by-year fixed effects, instead of bank-fixed $\left(\gamma_{\mathrm{i}}\right)$ and year-fixed effects $\left(\delta_{\mathrm{t}}\right)$. This specification controls for country-specific shocks and time trends.

If an AFS loss in the previous (current) period induces bank managers to take corrective actions, we should observe a positive coefficient estimate for $\beta_{1}\left(\beta_{3}\right)$. If prudential filters mute this relation, we expect a negative coefficient estimate for $\beta_{2}\left(\beta_{4}\right)$. In untabulated analyses, we find that AFS losses exhibit parallel trends or patterns over the sample period across the two filter groups, which is reassuring. As a robustness check, we also estimate a continuous version of our regression model expressed in (1). We estimate the following regression model:

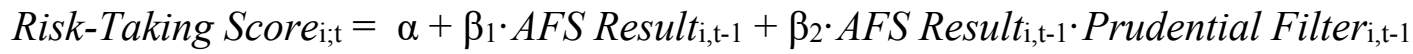

$$
\begin{aligned}
& +\beta_{3} \cdot \text { AFS Result } \mathrm{i}, \mathrm{t}+\beta_{4} \cdot \text { AFS Result } \mathrm{i}, \mathrm{t} \cdot \text { Prudential Filter } \mathrm{i}, \mathrm{t}-1 \\
& +\beta_{5} \cdot \text { Prudential Filter } \mathrm{i}, \mathrm{t}-1+\beta_{6} \text { Controls }_{\mathrm{i}, \mathrm{t}}+\gamma_{\mathrm{i}}+\delta_{\mathrm{t}}+\varepsilon_{\mathrm{i}, \mathrm{t}}
\end{aligned}
$$

where $i$ again denotes the individual bank and $t$ denotes the fiscal year. We create a composite Risk-Taking Score (PCA) for each bank year, which combines the levels of four variables (Dividend Payouts, Risk-Weighted Assets, Leverage, and Share Capital) using principal components analysis. We sum the scores of the first two principal components, each weighted by 
the relative magnitude of their eigenvalues. The composite score increases in Dividend Payouts and Risk-Weighted Assets and decreases in Leverage and Share Capital. Higher values for the composite score should indicate more risk taking (or fewer corrective actions). AFS Result is the sum of realized and unrealized gains and losses from AFS assets during the current period, scaled by total assets. As specification (2) inverts the left- and right-hand side variables relative to the regression model in (1), we again expect a positive coefficient on lagged and current AFS results. If prudential filters mute this relation, we expect negative coefficient estimates for $\beta_{2}$ and $\beta_{4}$.

In both models, we include controls for bank characteristics, i.e., concurrent performance in the trading portfolio, return on assets, capital adequacy, and size. We interact the controls for capital adequacy and size with the Prudential Filter indicator to capture potential differences in bank characteristics across the two groups of countries. We include either bank and year (or country-by-year) fixed effects. We cluster standard errors by country. We provide summary statistics for all variables in the Online Appendix.

\subsection{Results and discussion}

Table 6 presents the results from model (1) in Columns 1 to 5 and from model (2) in Column 6. Past losses from AFS securities are positively associated with the Corrective Action Score (summarizing dividend cuts, RWA cuts, leverage cuts, and capital raising) in all five specifications (significant at the $1 \%$ level). This finding is consistent with the notion that banks respond to AFS losses with corrective actions. However, this relation is muted or essentially undone for banks that are subject to a $100 \%$ AOCI filter, as indicated by a significantly negative interaction term, which is of similar magnitude as the main effect. The latter is weaker for current-period AFS losses but the interaction with Prudential Filter is again significantly negative. As the specifications in Columns 1 to 5 are using a loss dummy, we check that the results are robust to controlling for the 
level of the AFS result (Column 3). Moreover, we obtain very similar results when we use exploit within-country variation using country fixed effects (Column 4) and, more importantly, countryby-year fixed effects, which control for arbitrary country shocks and time trends (Column 5). ${ }^{44}$

The results are very similar when we use the continuous Risk-Taking Score and the continuous AFS result (model 2). The composite score for risk taking is positively associated with both the lagged and current AFS result (statistically significant at the $1 \%$ level). The interaction of the lagged AFS result with Prudential Filter is statistically insignificant but negative and sizeable in magnitude. The interaction of the current AFS result with Prudential Filter is negative and statistically significant (at the $1 \%$ level). These results are again consistent with the idea that prudential filters mute incentives for early corrective actions.

In untabulated tests, we find that the interaction term of interest continues to be negative when we restrict the sample period to the years from 2006 to 2008, but its statistical significance decreases below conventional levels due to the decrease in sample size from 2,198 to 577. In addition, we estimate the coefficient for the main variable of interest $\left(\beta_{2}\right)$, i.e., the interaction of the lagged AFS loss (or result) with prudential filters, over time. We plot these estimates in Figure 4 and find that the negative interaction stems primarily from 2006 and 2011 onwards. This pattern is reassuring as 2006 and to a lesser extent 2011 and 2013 were years for which AFS losses were more prevalent and banks' AFS results declined, presumably due to increasing interest rates. Our results suggest an interesting link between monetary policy, corresponding AFS results and banks' corrective actions (when there is no AOCI filter). As central banks raise interest rates towards the peak of an economic boom, banks experience lower AFS results or even AFS losses, which

\footnotetext{
${ }^{44}$ Note that the main effect for Prudential Filter is not subsumed because it varies within countries when IFRSadopting banks apply local GAAP when determining regulatory capital. AFS losses of these banks are mechanically excluded from regulatory capital, irrespective of the country-specific filter.
} 
according to our results makes it more likely that banks take early (corrective) actions as risks are building up, but only when there are no prudential filters. We leave it for future research to explore this mechanism in more detail.

In sum, with a $100 \%$ AOCI filter, banks appear to be less inclined to take corrective actions in response to AFS losses, such as cutting dividends, reducing leverage and RWAs, or raising new capital. While we do not claim that our analysis delivers causal identification, we note that we exploit both changes in prudential filters over time and within-country variation. Overall, we show that incentives for corrective actions can be related to how prudential regulation uses accounting numbers. Our findings are consistent with the notion that bank managers have stronger incentives to take early corrective actions when FV losses are not completely filtered and hence reduce regulatory capital. As such, our evidence highlights that prudential filters can have side (or incentive) effects and that AFS losses can be triggers for corrective actions. We acknowledge that corrective actions, if they come too late, could also involve fire sales of AFS securities, which in turn could create problems. We do not have the data to examine this possibility. ${ }^{45}$ However, at a minimum, the incentive effects of prudential filters need to be part of the regulatory debate as they question the notion that prudential filters necessarily foster financial stability.

\section{Conclusion and suggestions for future research}

The financial crisis triggered an extensive debate about bank disclosure and loss recognition. In this debate, two concerns featured prominently: the destabilizing effect of negative disclosures

${ }^{45}$ There is little evidence of accounting-induced fire sales by commercial banks during the financial crisis (see also references in Fn. 41). However, it is possible that banks held on to AFS securities in part due to the presence of AOCI filters. We need more research into this matter. 
and the delay of loan loss recognition. In this paper, we investigate these issues and discuss what we can learn from the financial crisis about the link between accounting and financial stability.

Our analysis shows that banks' disclosures about relevant risk exposures as well as the accounting recognition of loan losses came late, relative to the evolution of the crisis and concurrent market expectations. It appears that many banks were reluctant to communicate and recognize their losses. We do not find strong adverse market responses to banks' initial disclosures of subprime exposures. At the same time, these disclosures did little to resolve the large uncertainty in the market. Instead, relatively vague disclosures and repeated upward revisions in banks' exposures, asset impairments and losses were prevalent. Thus, our interpretation of the evidence is that the problem was not that investors overreacted to bank information, but that they didn't have sufficiently reliable disclosures.

Our analysis supports the concerns of financial regulators that banks were late in recognizing their loan losses, and points to banks' reporting incentives as an important factor influencing the delay in loss recognition. Banks have several ways to communicate expected losses to investors that are not constrained by the recognition rules. We find that many banks did not use these channels. In addition, we provide evidence from the ECB's Asset Quality Review that many large European banks were not constrained in their loan loss recognition by the prevailing rules (or the incurred loss model). Consistent with this interpretation, we provide evidence that the ECB's loan valuation adjustments are concentrated in banks that are close to their capital constraints, pointing to regulatory capital constraints as a source of the incentives.

In sum, our evidence on banks' disclosures and loss recognition points to the importance of banks' reporting incentives for observed reporting behavior and, in particular, for the reluctance to communicate and recognize losses. Moreover, the use of accounting discretion to avoid loss 
recognition is negatively correlated with banks' incentives to engage in corrective actions. These results raise the question of whether the new expected credit loss model will indeed have the intended effects, considering its forward-looking nature gives even more discretion to banks.

Lastly, we present novel evidence consistent with the idea that prudential filters, because they shield regulatory capital, dampen banks' incentives for early (corrective) actions in response to losses from their debt securities. Such losses can arise when central banks raise interest rates at the tail end of a boom as well as early in a crisis when markets begin to price increases in default risk. Our finding connects with a broader theme in bank regulation: Ex-post measures, intended to improve financial stability when a crisis is in full swing, often have ex-ante side effects with respect to banks' actions (at which point the crisis could perhaps still be averted).

In closing, we highlight several opportunities for future research that are closely related to our analysis and the evidence that has emerged since the crisis. First, once debt overhang problems arise, disclosures or financial reports alone can do little to resolve them. ${ }^{46}$ Thus, the debate should focus on the role of accounting, be it through disclosure or recognition, at an earlier stage. One question is whether accounting can contribute to financial stability by providing banks with incentives to take corrective actions early, reduce risk taking or avoid debt overhang problems in the first place. Our evidence is only a start. We need to understand much better how the recognition of losses affects bank behavior early in a crisis and also what role regulators play, for instance, by enforcing the accounting standards and the recognition of losses.

Second, providing banks with incentives to act early is challenging. Corrective actions are themselves a signal that a bank experiences difficulties, which in turn could destabilize the bank

${ }^{46}$ Of course, reliable information about banks' assets and liabilities can help supervisors with the resolution of overhang through restructuring, selling or liquidation (e.g., Granja, 2013). But for such actions, supervisors typically have access to internal information and do not solely rely on public disclosures and reports. 
and counteract the corrective measures if the market learns about the difficulties through the corrective actions. Especially banks that rely heavily on short-term funding will be reluctant to take actions that could be viewed as a sign that they are in trouble (such as cutting dividends or raising capital). Thus, the incentives have to come early enough so that the bank can take actions without triggering problems even if investors interpret the actions as a negative signal. We lack research on this challenge.

A third (and related) opportunity arises from our evidence that prudential filters appear to dampen banks' incentives to take prompt corrective actions precisely because they shield banks' regulatory capital. Thus, the evidence points to a link between losses and corrective actions, at least early on and when banks still have room to take these losses. Future research could explore this mechanism in more detail and, in particular, examine how it relates to monetary policy. When central banks raise interest rates towards the peak of an economic boom, banks experience FV losses on debt securities, which hit regulatory capital if there are no prudential filters.

We believe the COVID-19 crisis provides an opportunity to study several of these interactions, including the role of regulators. This crisis undoubtedly increases banks' credit risk (and hence expected losses), despite widespread government support for firms. Yet, banks have time to react, the crisis does not stem from excessive risk-taking by banks, and the market will not be surprised if banks need to take corrective measures such as raising equity. Thus, the COVID-19 crisis seems to be a situation, in which banks could act early to prepare for potential problems, without triggering concerns by investors. Moreover, given the concerns about the incurred loss model, it seems that regulators should be content that the rules now stipulate an expected credit loss model. However, regulators and policymakers have already called for a longer transition period and flexibility in the application of the new accounting standards, including temporary suspensions 
and relief of its effect on regulatory capital. Their key argument is that the expected loss model would contribute to procyclicality ${ }^{47}$ However, a temporary halt or relaxation of the expected loss model is akin to a prudential filter and hence could dampen banks' incentives to take actions early in the COVID-19 crisis when it is easier for them to do so. Thus, studying the responses of regulators and banks will yield interesting insights with respect to key themes of our paper.

Finally, accounting measurement still relies heavily on banks' intention to sell or hold an asset. For instance, IFRS 9 stipulates the use of amortized costs if a bank has the intent to hold an asset until its maturity to collect its contractual cash flows. While the standard setter explicitly mentions "ability" to hold an asset until maturity in addition to intent, this "ability" can quickly change in a crisis when a bank relies on short-term funding. Moreover, auditors or regulators could be reluctant to question a bank's "ability" to hold assets to maturity given the potential adverse consequences of such a question, especially when a bank has to roll over its funding. Thus, it is not clear that one can determine the measurement of asset values independent of a bank's funding structure. Similarly, funding structure and regulatory capital requirements can affect banks' incentives to recognize losses, which in turn can affect the measurement banks choose for their assets. It is important to understand these interactions between funding structures, accounting measurement and prudential regulation. We encourage future research in this direction.

${ }^{47}$ See, for example, the Basel Committee on Banking Supervision (2020), Borio and Restroy (2020), European Central Bank (2020), Financial Times (2020), and Wall Street Journal (2020) for some of the arguments and measures taken. See also Laux (2012), who pointed out that regulators may be ready to change expected credit loss models in a crisis due to procyclicality concerns and the potential effects this may have on banks' incentives. 


\section{References}

Abad, J., and J. Suarez. 2018. Assessing the procyclicality of expected credit loss provisions. CEPR Discussion Paper No. DP13135.

Abbassi, P., R. Iyer, J.L. Peydró, and F.R. Tous. 2016. Securities trading by banks and credit supply: Micro-evidence from the crisis. Journal of Financial Economics, 121 (3): 569-594.

Acharya, V.V., I. Gujral, N. Kulkarni, and H.S. Shin. 2011. Dividends and bank capital in the financial crisis of 2007-2009. NBER Working Paper No. 16896.

Acharya, V.V., and S.G. Ryan. 2016. Banks' financial reporting and financial system stability. Journal of Accounting Research, 54 (2): 277-340.

Acharya, V.V., P. Schnabl, and G. Suarez. 2013. Securitization without risk transfer. Journal of Financial Economics, 107 (3): 515-536.

Ahmed, A.S., E. Kilic, and G.J. Lobo. 2006. Does recognition versus disclosure matter? Evidence from value-relevance of banks' recognized and disclosed derivative financial instruments. The Accounting Review, 81 (3): 567-588.

Aiyar, S., C.W. Calomiris, J. Hooley, Y. Korniyenko, and T. Wieladek. 2014a. The international transmission of bank capital requirements: Evidence from the UK. Journal of Financial Economics, 113 (3): 368-382.

Aiyar, S., C.W. Calomiris, and T. Wieladek. 2014b. Does macro-prudential regulation leak? Evidence from a UK policy experiment. Journal of Money, Credit and Banking, 46 (1): 181214.

American Bankers Association (ABA). 2009. Comment Letter to IASB on the Exposure Draft to IFRS 9 Financial Instruments: Classification and Measurement.

Ashcraft, A., P. Goldsmith-Pinkham, P. Hull, and J. Vickery. 2011. Credit ratings and security prices in the subprime MBS market. American Economic Review: Papers \& Proceedings, 101 (3): 115-119.

Badertscher, B.A., J.J. Burks, and P.D. Easton. 2012. A convenient scapegoat: Fair value accounting by commercial banks during the financial crisis. The Accounting Review, 87 (1): $59-90$. 
Badertscher, B.A., J.J. Burks, and P.D. Easton. 2014. The Market Pricing of Other-ThanTemporary Impairments. The Accounting Review, 89 (3): 811-838.

Ball, R., A. Robin, and J.S. Wu. 2003. Incentives versus standards: properties of accounting income in four East Asian countries. Journal of Accounting and Economics, 36 (1-3): 235270 .

Barth, M.E., J. Gomez-Biscarri, R. Kasznik, and G. López-Espinosa. 2017. Bank earnings and regulatory capital management using available for sale securities. Review of Accounting Studies, 22 (4): 1761-1792.

Barth, M.E., and W. R. Landsman. 2010. How did financial reporting contribute to the financial crisis? European Accounting Review, 19 (3): 399-423.

Basel Committee on Banking Supervision. 2011. Comment letter: Financial instruments: Impairment. Basel, https://www.bis.org/bcbs/commentletters/iasb32.pdf.

Basel Committee on Banking Supervision. 2015. Guidance on credit risk and accounting for expected credit losses. Basel, https://www.bis.org/bcbs/publ/d350.pdf.

Basel Committee on Banking Supervision. 2020. Measures to reflect the impact of Covid-19. April.

Beatty, A. 1995. The effects of fair value accounting on investment portfolio management: How fair is it? Federal Reserve Bank of St. Louis Review, 77 (1): 25-39.

Beatty, A., and S. Liao. 2011. Do delays in expected loss recognition affect banks' willingness to lend? Journal of Accounting and Economics, 52 (1): 1-20.

Beaver, W., C. Eger, S. Ryan, and M. Wolfson. 1989. Financial Reporting, Supplemental Disclosures, and Bank Share Prices. Journal of Accounting Research, 27 (2): 157-178.

Behn, M., R. Haselmann, and P. Wachtel. 2016a. Procyclical capital regulation and lending. The Journal of Finance, 71 (2): 919-956.

Behn, M., R. Haselmann, and P. Wachtel. 2016b. The limits of model-based regulation. Working Paper, European Central Bank.

Ben-David, I., A.A. Palvia, and R.M. Stulz. 2019. Do distressed banks really gamble for resurrection? Charles A. Dice Working Paper No. 2019-10. 
Benmelech, E., and J. Dlugosz. 2009. The credit ratings crisis. NBER Macroeconomics Annual: 161-207.

Bernanke, B. 2009. Financial reform to address systemic risk. Remarks at the Council on Foreign Relations, March 10. Washington, D.C., https://www.federalreserve.gov/newsevents/speech/ bernanke20090310a.htm

Bhat, G., R. Frankel, and X. Martin. 2011. Panacea, Pandora's box, or placebo: Feedback in bank holdings of mortgage-backed decurities and fair value accounting. Journal of Accounting and Economics, 52 (2-3): 153-173.

Bierey, M., and M. Schmidt. 2017. Banks' use of accounting discretion and regulatory intervention: The case of European banks' impairments on Greek government bonds. The International Journal of Accounting, 52 (2): 122-141.

Bischof, J., and H. Daske. 2013. Mandatory disclosure, voluntary disclosure, and stock market liquidity: Evidence from the EU bank stress tests. Journal of Accounting Research, 51 (5): 997-1029.

Bischof, J., U. Brüggemann, and H. Daske. 2019. Asset reclassifications and bank recapitalization during the financial crisis. Working paper, University of Mannheim.

Borio, C., and F. Restroy. 2020. Reflections on regulatory responses to the Covid-19 pandemic. Financial Stability Institute (FSI) Briefs, No 1.

Bouvard, M., P. Chaigneau, and A. De Motta. 2015. Transparency in the financial system: Rollover risk and crises. The Journal of Finance, 70 (4): 1805-1837.

Bowen, R.M., and U. Khan. 2014. Market reactions to policy deliberations on fair value accounting and impairment rules during the financial crisis of 2008-2009. Journal of Accounting and Public Policy, 33 (3): 233-259.

Burgstahler, D.C., L. Hail, and C. Leuz. 2006. The importance of reporting incentives: Earnings management in European private and public firms. The Accounting Review, 81 (5): 983-1016.

Bushman, R.M., and C.D. Williams. 2015. Delayed expected loss recognition and the risk profile of banks. Journal of Accounting Research, 53 (3): 511-553.

Calomiris, C.W. 2008. The subprime turmoil: What's old, what's new, and what's next. Proceedings - Economic Policy Symposium - Jackson Hole, Federal Reserve Bank of Kansas City: 19-110. 
Calomiris, C.W., and D. Nissim. 2014. Crisis-related shifts in the market valuation of banking activities. Journal of Financial Intermediation, 23 (3): 400-435.

Cantrell, B.W., J.M. McInnis, and C.G. Yust. 2014. Predicting credit losses: loan fair values versus historical costs. The Accounting Review, 89 (1): 147-176.

Chae, S., R.F. Sarama, C.M. Vojtech, and J. Wang. 2018. The impact of the current expected credit loss standard (CECL) on the timing and comparability of reserves. Finance and Economics Discussion Series 2018-020. Washington: Board of Governors of the Federal Reserve System.

CEBS. 2008. CEBS report on banks' transparency on activities and products affected by the recent market turmoil. https://www.eba.europa.eu/documents/20080618a_transparency.pdf.

Chircop, J., and Z. Novotny-Farkas. 2016. The economic consequences of extending the use of fair value accounting in regulatory capital calculations. Journal of Accounting and Economics, 62 (2-3): 183-203.

Costello, A., J. Granja, and J. Weber. 2019. Do strict regulators increase the transparency of the banks? Journal of Accounting Research, 57 (3): 603-637.

Curry, T.J. 2013. Remarks by T.J. Curry, Comptroller of the Currency, before the AICPA Banking Conference, September 16, Washington DC.

DeFond, M.L., C. Lennox, and J. Zhang. 2018. The primacy of fair presentation: Evidence from PCAOB standards, Federal Legislation, and the Courts. Accounting Horizons, 32 (3): 91-100.

Desai, H., S. Rajgopal, and J.J. Yu. 2015. Were information intermediaries sensitive to the financial statement-based lading indictors of bank distress prior to the financial crisis? Contemporary Accounting Research, 33 (2): 576-606.

Dong, M., and X.J. Zhang. 2018. Selective trading of available-for-sale securities: evidence from U.S. commercial banks. European Accounting Review, 27 (3): 467-493.

Dugan, J.C. 2009. Loan loss provisioning and pro-cyclicality. Remarks by J.C. Dugan, Comptroller of the Currency, before the Institute of International Bankers, March 2, Washington DC.

Ellul, A., C. Jotikasthira, C.T. Lundblad, and Y. Wang. 2014. Mark-to-market accounting and systemic risk in the financial sector. Economic Policy, 29 (78): 297-341. 
Ellul, A., C. Jotikasthira, C.T. Lundblad, and Y. Wang. 2015. Is historical cost accounting a panacea? Market stress, incentive distortions, and gains trading. The Journal of Finance, 70 (6): 2489-2538.

Erel, I., T. Nadauld, and R.M. Stulz. 2013. Why did holdings of highly rated securitization tranches differ so much across banks? Review of Financial Studies, 27 (2): 403-453.

European Central Bank. 2020. IFRS 9 in the context of the coronavirus (COVID-19) pandemic. Letter to all significant institutions, No. SSM-2020-0154.

European Commission. 2016. Commission Regulation (EU) 2016/2067 adopting IFRS 9. https://eur-lex.europa.eu/eli/reg/2016/2067/oj.

Federal Deposit Insurance Corporation. 2006. Interagency policy statement on the Allowance for Loan and Lease Losses.

Financial Accounting Standards Board (FASB). 2016. Measurement of credit losses on financial instruments. Financial instruments - credit losses, Topic 326.

Financial Crisis Advisory Group (FCAG). 2009. Report of the Financial Crisis Advisory Group. July 28 .

Financial Stability Forum. 2009. Report on addressing procyclicality in the financial system.

Financial Times. 2007. D Bank chief told regulator IKB was in trouble. August 3, p. 22 (print).

Financial Times. 2020. New accounting rules pose threat to banks amid coronavirus crisis. March 17 (online), March 18, p. 16 (print).

Gallemore, J. 2018. Bank financial reporting opacity and regulatory intervention. Working paper, University of Chicago - Booth School of Business.

Goldstein, I., and Y. Leitner. 2018. Stress tests and information disclosure. Journal of Economic Theory, 177: 34-69.

Goldstein, I., and H. Sapra. 2014. Should banks' stress test results be disclosed? An analysis of the costs and benefits. Foundations and Trends in Finance, 8 (1): 1-54.

Gorton, G.B. 2008. The panic of 2007. Proceedings - Economic Policy Symposium - Jackson Hole, Federal Reserve Bank of Kansas City: 131-262.

Granja, J. 2013. The relation between bank resolutions and information environment: evidence from the auctions for failed banks. Journal of Accounting Research, 51 (5): 1031-1070. 
Granja, J. 2018. Disclosure regulation in the commercial banking industry: Lessons from the national banking era. Journal of Accounting Research, 56 (1): 173-216.

Granja, J., and C. Leuz. 2019. The Death of a Regulator: Strict Supervision, Bank Lending and Business Activity. Working Paper, University of Chicago.

Group of Twenty (G20). 2009. Declaration on strengthening the financial system. London Summit, April 2.

Hamilton, D. 2018. Fear of (capital) commitment: Strategic accounting classifications and the consequences for fixed income dealer inventories, Working Paper.

Hanley, K.W., A.D. Jagolinzer, and S. Nikolava. 2018. Strategic estimation of asset fair values. Journal of Accounting and Economics, 66 (1): 25-45.

He, J., J. Qian, and P.E. Strahan. 2011. Credit ratings and the evolution of the mortgage-backed securities market. American Economic Review: Papers \& Proceedings, 101 (3): 131-135.

Hodder, L., M. Kohlbeck, and M. McAnally. 2002. Accounting choices and risk management: SFAS No. 115 and US bank holding companies. Contemporary Accounting Research, 19 (2): 225-270.

Horowitz, K., S. Foundos, and C. Singer. 2009. U.S. Banks: Assessing risk/reward under various stress test scenarios. Citigroup Global Markets, Investment Report, March 2.

Huizinga, H., and L. Laeven. 2012. Bank valuation and accounting discretion during a financial crisis. Journal of Financial Economics, 106 (3): 614-634.

Jiménez, G., S. Ongena, J.L. Peydró, and J. Saurina. 2017. Macroprudential policy, countercyclical bank capital buffers, and credit supply: Evidence from the Spanish dynamic provisioning experiments. Journal of Political Economy, 125 (6): 2126-2177.

Khan, U., S.G. Ryan, and A. Varma. 2019. Fair values versus amortized cost measurement and the timeliness of other-than-temporary impairments: evidence from the insurance industry. The Accounting Review, 94 (6): 285-307.

Kim, S., S. Kim, and S.G. Ryan. 2019. Economic consequences of the AOCI filter removal for advanced approaches banks. The Accounting Review, 94 (6): 309-335.

Laux, C., and C. Leuz. 2009. The crisis of fair-value accounting: Making sense of the recent debate. Accounting, Organizations and Society, 34 (6-7): 826-834. 
Laux, C., and C. Leuz. 2010. Did fair-value accounting contribute to the financial crisis? Journal of Economic Perspectives, 24 (1): 93-118.

Laux, C. 2012. Financial instruments, financial reporting, and financial stability, Accounting and Business Research 42 (3): 1-22.

Laux, C., and T. Rauter. 2017. Procyclicality of U.S. bank leverage. Journal of Accounting Research, 55 (2): 237-273.

Leuz, C. 2003. IAS versus U.S. GAAP: Information asymmetry-based evidence from Germany's new market. Journal of Accounting Research, 41 (3): 445-472.

Merrill, C.B., T.D. Nadauld, R.M. Stulz, and S. Sherlund. 2014. Did capital requirements and fair value accounting spark fire sales in distressed mortgage-backed securities? NBER Working Paper No. 18270.

Morris, S., and H.S. Shin. 2002. Social value of public information. American Economic Review, 92 (5): 1521-1534.

Nissim, D. 2003. Reliability of Banks' Fair Value Disclosures for Loans. Review of Quantitative Finance and Accounting, 20 (4): 355-384.

Ryan, S.G. 2008. Accounting in and for the subprime crisis. The Accounting Review, 83 (6): 16051638.

Ryan, S.G., and J.H. Keeley. 2013. Discussion of "Did the SEC impact banks' loan loss reserve policies and their informativeness?" Journal of Accounting and Economics, 56 (2-3), Supplement 1: 66-78.

Valukas, A. 2010. Lehman Brothers Holdings Inc. Chapter 11 Proceedings Examiner Report. https://jenner.com/lehman.

Vyas, D. 2011. The timeliness of accounting write-downs by U.S. financial institutions during the financial crisis of 2007-2008. Journal of Accounting Research, 49 (3): 823-860.

Wall, L.D. 2013. FASB proposes (too?) early loan loss recognition. Notes from the vault. Center for Financial Innovation and Stability at the Atlanta Federal Reserve Bank.

Wall Street Journal. 2008. The fall of Bear Stearns. May 27-29, p. A1 (print).

Wall Street Journal. 2020. FDIC Chairman asks for accounting-policy changes due to coronavirus. March 19 (online). 
Xie, B. 2016. Does fair value accounting exacerbate the procyclicality of bank lending? Journal of Accounting Research, 54 (1): 235-274. 


\section{Figure 1: Market Reactions around the Initial Disclosures of U.S. Banks' Subprime Exposures}

\section{Panel A: Individual Banks' Disclosures (in event time)}

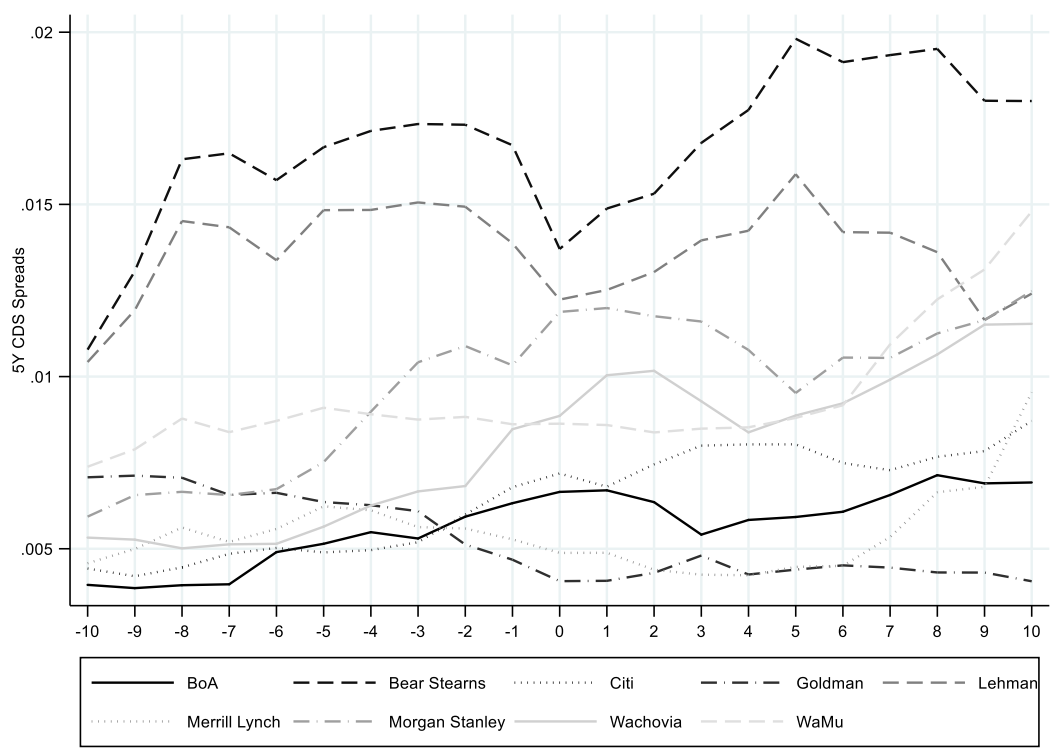

Panel B: Disclosures by Merrill Lynch and Washington Mutual on October 5, 2007

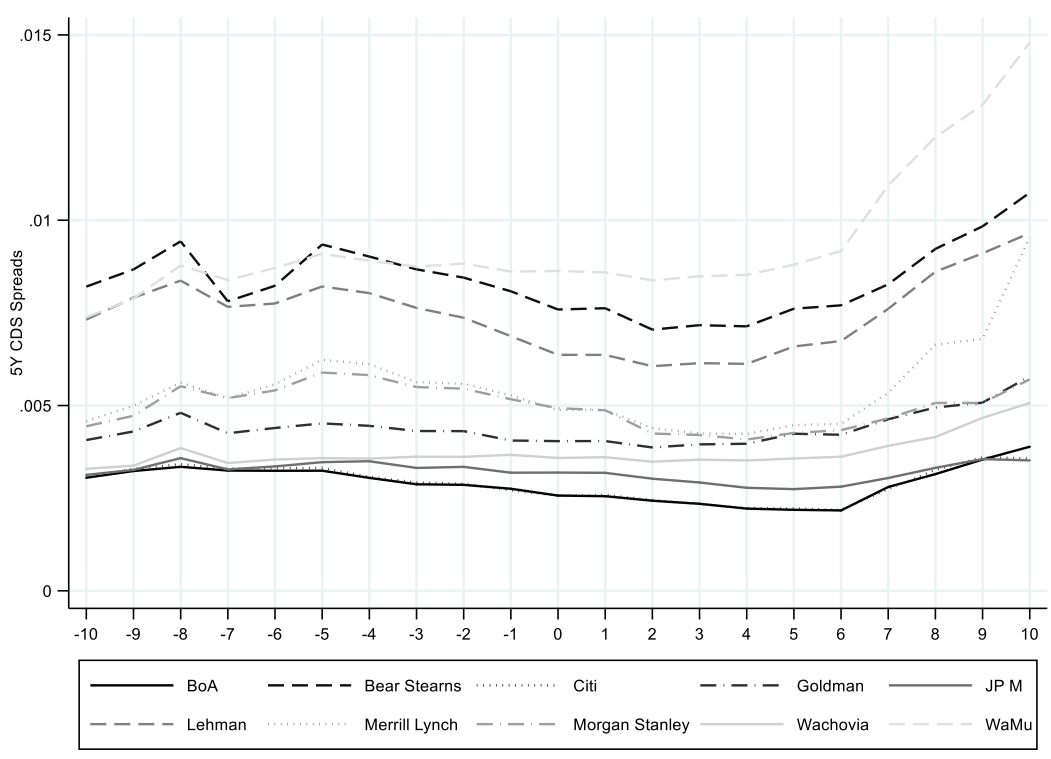

The figures plot the 5-year CDS spreads for nine US banks around their initial disclosures of subprime exposures (Panel A) and around the disclosures by Merrill Lynch and Washington Mutual on October 5, 2007 (Panel B). Panel A does not include JP Morgan because their initial disclosures came before 2007. All CDS pricing data come from IHS Markit. We restrict the data to 5 -year CDS contracts denominated in USD, with modified restructuring clauses, and of senior unsecured debts. 


\section{Figure 2: Market Reactions around the SEC Letter to Lehman}

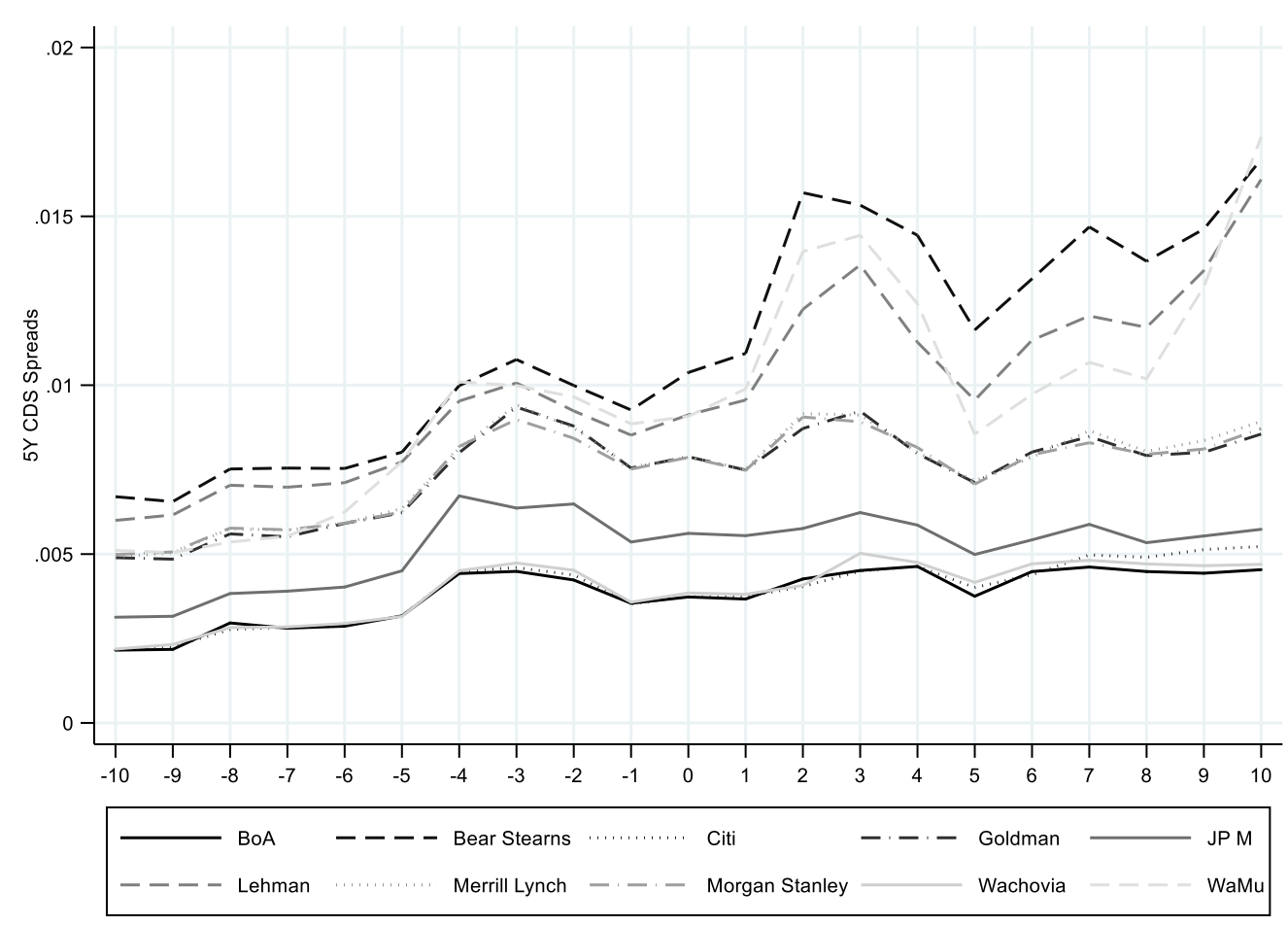

The figure plots the 5-year CDS spreads for 10 US banks around the publication of the SEC's letter to Lehman on August 1, 2007. In the letter, the SEC expressed concerns about the adequacy of Lehman's disclosures with respect to their subprime exposure. All CDS pricing data come from IHS Markit. We restrict the data to 5-year CDS contracts denominated in USD, with modified restructuring clauses, and of senior unsecured debts. 


\section{Figure 3: 8-K Filings with Loan Loss Disclosures by U.S. Financial Institutions}

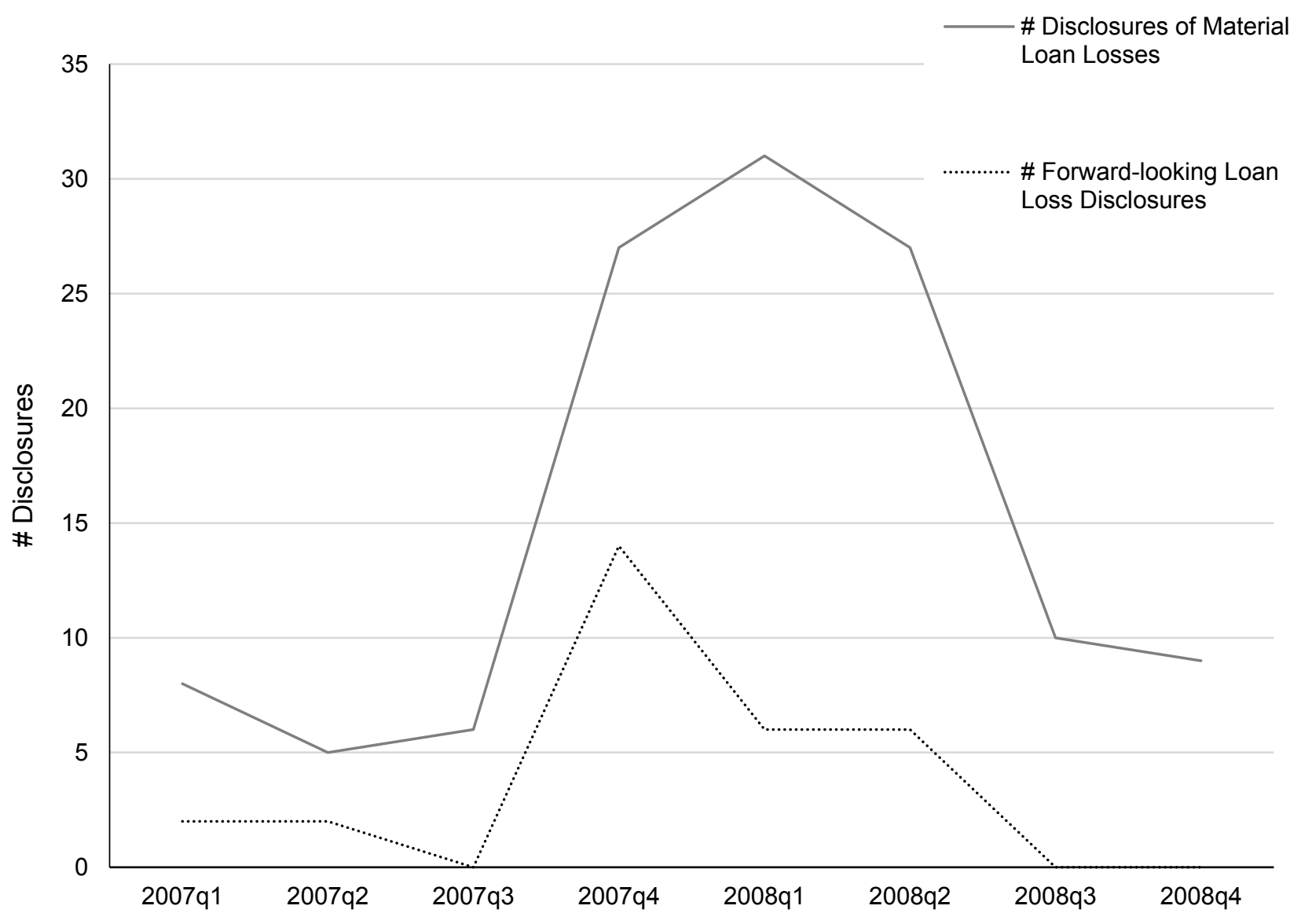

The figure presents the number of 8-K filings by U.S. financial institutions between 2007-Q1 and 2008-Q4 that include a material loan loss (or impairment) disclosure in items 2.06 (Material Impairments), 4.02 (Non-Reliance on Previously Issued Financial Statements or a Related Audit Report or Completed Interim Review), 7.01 (Regulation FD), or 8.01 (Other Events). The automated search yielded all 8-K filings that included both an equivalent term for loan ("loan", "loans", "mortgage", "mortgages") and for loss ("loss", "losses", "lose", "loses", "losing", "lost", "decrease", "decreases", "decreasing", "decreased", "write down", "write-down", "writes down", "writing down", "wrote down", "written down", "write downs", "write-downs", "write off", "writes off", "writing off", "write-off", "write offs", "write-offs", "wrote off", "written off", "reduction", "reductions", "reduce", "reduces", "reducing", "reduced") within a range of five words. We manually check each disclosure identified through this procedure and verify that it relates to loan losses. We identify a total of 123 relevant 8-K disclosures in 2007 and 2008. The solid gray line shows the quarterly number of 8-K reports with loan loss disclosures (about past, incurred and future losses). We define a forward-looking disclosure as one in which a bank discloses a loan loss that has not yet been recognized in the current (or a previous) quarter. That is, the disclosure is not simply a profit warning or pre-announcement for the upcoming financial report (10-Q or 10-K). We find a total of 30 forward-looking disclosures. The dotted black line shows the quarterly number of $8-\mathrm{K}$ reports with forward-looking loan loss disclosures. 
Figure 4: Mapping out the Interaction between AFS Losses and Prudential Filter over Time

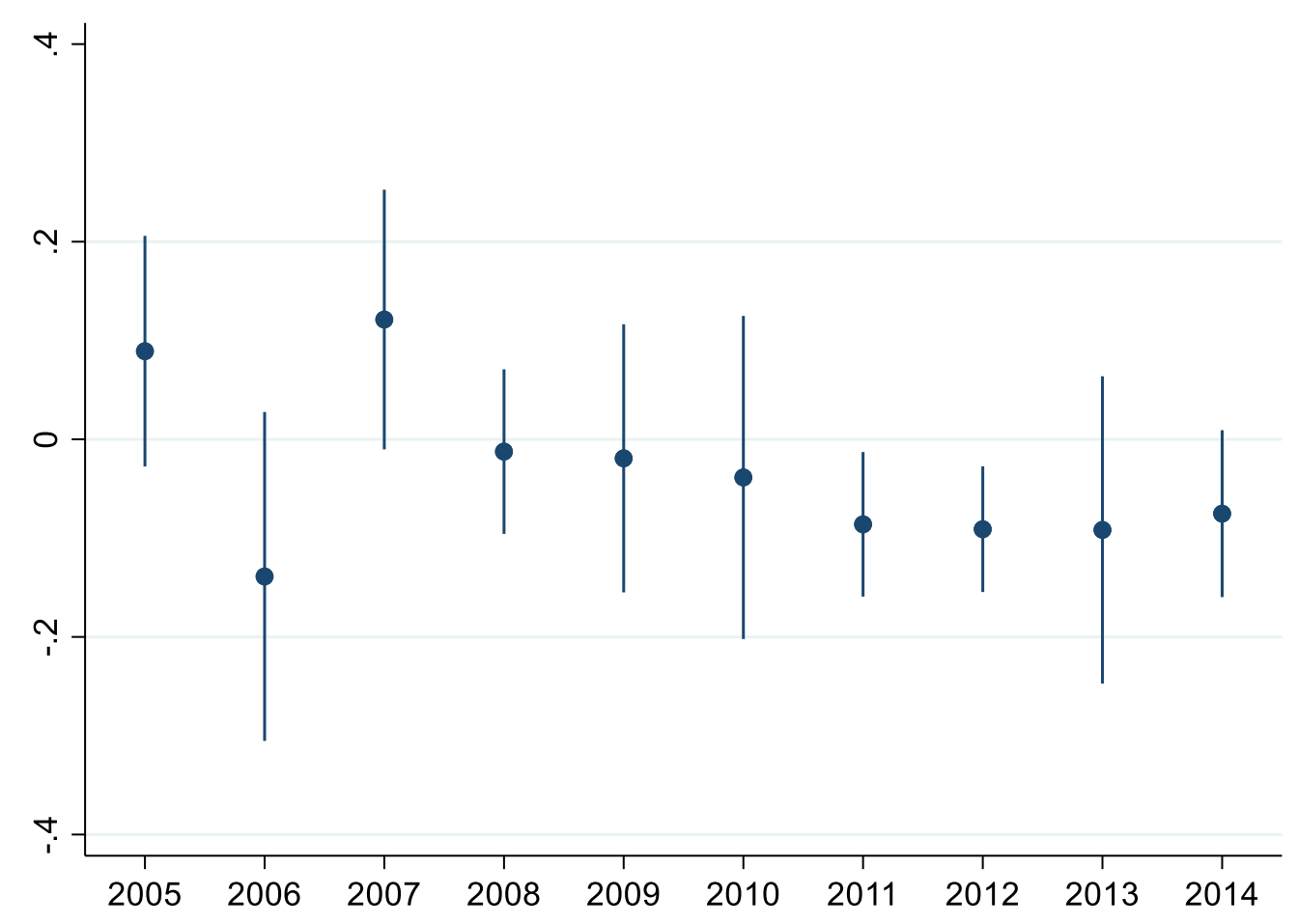

The figure maps out and presents the coefficient estimates and $90 \%$ confidence intervals for the interaction term $A F S \operatorname{Loss}_{\mathrm{i}, \mathrm{t}-\mathrm{1}}$ * Prudential Filter i,t-1 $_{\text {for }}$ each year. When estimating equation (1), we add a year dummy to the interaction term to obtain yearly point estimates for the interaction term. See the notes for Table 6 for further details. 
Table 1: Overview of Disclosures, Impairments, Reporting Choices and Corrective Actions by International Banks during the 2007-08 Crisis

Panel A: US Banks

\begin{tabular}{|c|c|c|c|c|c|}
\hline & Bank of America & Bear Stearns & Citigroup & Goldman & JP Morgan \\
\hline Failure or Intervention Date & - & $3 / 16 / 2008$ & - & - & - \\
\hline $\begin{array}{l}\text { Initial Disclosure of Subprime } \\
\text { Exposure }\end{array}$ & 11/09/2007 (10-Q) & $\begin{array}{l}11 / 14 / 2007(8-K) \\
1 / 29 / 2008(10-K)\end{array}$ & $11 / 05 / 2007(10-Q)$ & $\begin{array}{c}\text { 9/20/2007 (8-K) } \\
10 / 10 / 2007(10-\mathrm{Q})\end{array}$ & before 2007 \\
\hline Initial Impairments & Q3-2007 & $11 / 14 / 2007(8-K)$ & Q3-2007 & Q3-2007 & Q1-2007 \\
\hline $\begin{array}{l}\text { Disclosure of Funding } \\
\text { Structure (2007-Q4) }\end{array}$ & yearly time bands & yearly time bands & yearly time bands & quarterly time bands & yearly time bands \\
\hline $\begin{array}{l}\text { Disclosure of Interest Rate } \\
\text { Sensitivity (2007-Q4) }\end{array}$ & $\begin{array}{l}\text { parallel shifts } \\
(+/-100 \mathrm{bps})\end{array}$ & $\begin{array}{c}\text { parallel shifts } \\
(+/-50 \text { and } 100 \mathrm{bps})\end{array}$ & 6 scenarios & $95 \% \mathrm{VaR}$ & $\begin{array}{c}\text { parallel shifts } \\
(+/-100 \text { and } 200 \mathrm{bps})\end{array}$ \\
\hline \multicolumn{6}{|c|}{ Discretionary Accounting Choices: } \\
\hline $\begin{array}{l}\text { Reclassifications of Fair } \\
\text { Value Assets }\end{array}$ & No & No & Q4-2008 & No & No \\
\hline Transfers to Level 3 & 2007,2008 & 2007 & 2007,2008 & 2007,2008 & 2007,2008 \\
\hline $\begin{array}{l}\text { Gains from Increases in } \\
\text { Own Credit Risk }\end{array}$ & No & No & 2007,2008 & 2007,2008 & 2007,2008 \\
\hline \multicolumn{6}{|l|}{ Corrective Actions: } \\
\hline Dividend Cuts & Q4-2008 & $\mathrm{n} / \mathrm{a}$ & Q4-2008 & Q3-2007 & Q1-2009 \\
\hline Last Share Repurchase & Q4-2007 & Q4-2007 & Q1-2007 & Q4-2008 & Q3-2007 \\
\hline $\begin{array}{l}\text { Issuance of Equity } \\
\text { (including Preferred Stocks) }\end{array}$ & Q1-2008, Q2-2008 & $\mathrm{n} / \mathrm{a}$ & Q1-2008, Q2-2008 & every quarter & Q2-2008, Q3-2008 \\
\hline Government Support & Q4-2008 (TARP) & $\mathrm{n} / \mathrm{a}$ & Q4-2008 (TARP) & Q4-2008 (TARP) & Q4-2008 (TARP) \\
\hline \multicolumn{6}{|l|}{ Misstatement Litigation } \\
\hline $\begin{array}{l}\text { Bank } \\
\text { thereof: Public prosecution }\end{array}$ & $\begin{array}{c}\text { Yes } \\
\text { Yes (US SEC) }\end{array}$ & $\begin{array}{c}\text { Yes } \\
\text { Yes (US SEC) }\end{array}$ & $\begin{array}{c}\text { Yes } \\
\text { Yes (US SEC) }\end{array}$ & $\begin{array}{l}\mathrm{n} / \mathrm{a} \\
\mathrm{n} / \mathrm{a}\end{array}$ & $\begin{array}{c}\text { Yes } \\
\text { Yes (US SEC) }\end{array}$ \\
\hline Auditors & Yes & Yes & $\mathrm{n} / \mathrm{a}$ & $\mathrm{n} / \mathrm{a}$ & $\mathrm{n} / \mathrm{a}$ \\
\hline
\end{tabular}




\begin{tabular}{|c|c|c|c|c|c|}
\hline & Lehman & Merrill Lynch & Morgan Stanley & Wachovia & Washington Mutual \\
\hline Failure or Intervention Date & $9 / 15 / 2008$ & $9 / 15 / 2008$ & - & $10 / 3 / 2008$ & $9 / 25 / 2008$ \\
\hline $\begin{array}{l}\text { Initial Disclosure of Subprime } \\
\text { Exposure }\end{array}$ & $\begin{array}{l}11 / 14 / 2007(8-\mathrm{K}) \\
12 / 13 / 2007(10-\mathrm{K})\end{array}$ & $\begin{array}{c}10 / 5 / 2007(8-\mathrm{K}) \\
10 / 24 / 2007(10-\mathrm{Q})\end{array}$ & $\begin{array}{l}11 / 7 / 2007(8-K) \\
1 / 29 / 2008(10-K)\end{array}$ & 11/8/2007 (10-Q) & $\begin{array}{c}10 / 5 / 2007(8-\mathrm{K}) \\
10 / 17 / 2007(10-\mathrm{Q})\end{array}$ \\
\hline Initial Impairments & Q4-2007 & Q3-2007 & Q4-2007 & Q3-2007 & Q3-2007 \\
\hline $\begin{array}{l}\text { Disclosure of Funding } \\
\text { Structure (2007-Q4) }\end{array}$ & yearly time bands & yearly time bands & yearly time bands & yearly time bands & yearly time bands \\
\hline $\begin{array}{l}\text { Disclosure of Interest Rate } \\
\text { Sensitivity (2007-Q4) }\end{array}$ & $95 \% \mathrm{VaR}$ & $\begin{array}{l}\text { parallel shifts } \\
(+/-100 \mathrm{bps})\end{array}$ & $95 \% \mathrm{VaR}$ & 3 scenarios & $\begin{array}{l}\text { parallel shifts } \\
(+/-100 \mathrm{bps})\end{array}$ \\
\hline \multicolumn{6}{|c|}{ Discretionary Accounting Choices: } \\
\hline $\begin{array}{l}\text { Reclassifications of Fair } \\
\text { Value Assets }\end{array}$ & No & No & No & No & No \\
\hline Transfers to Level 3 & 2007 & 2007, 2008 & 2007,2008 & 2008 & 2008 \\
\hline $\begin{array}{l}\text { Gains from Increases in } \\
\text { Own Credit Risk }\end{array}$ & 2007,2008 & 2007, 2008 & 2007, 2008 & No & No \\
\hline \multicolumn{6}{|l|}{ Corrective Actions: } \\
\hline Dividend Cuts & $\mathrm{n} / \mathrm{a}$ & $\mathrm{n} / \mathrm{a}$ & Q2-2008 & Q2-2008 & Q1-2008 \\
\hline Last Share Repurchase & Q3-2007 & Q4-2007 & Q3-2008 & Q3-2008 & Q4-2007 \\
\hline $\begin{array}{l}\text { Issuance of Equity } \\
\text { (including Preferred Stocks) }\end{array}$ & Q1-2008, Q2-2008 & Q1-2008, Q2-2008 & every quarter & Q4-2007, Q1-2008 & Q4-2007, Q2-2008 \\
\hline Government Support & $\mathrm{n} / \mathrm{a}$ & $\mathrm{n} / \mathrm{a}$ & Q4-2008 (TARP) & $\mathrm{n} / \mathrm{a}$ & $\mathrm{n} / \mathrm{a}$ \\
\hline \multicolumn{6}{|l|}{ Misstatement Litigation } \\
\hline $\begin{array}{l}\text { Bank } \\
\text { thereof: Public prosecution }\end{array}$ & $\begin{array}{l}\text { Yes } \\
\text { n/a }\end{array}$ & $\begin{array}{c}\text { Yes } \\
\text { Yes (US SEC) }\end{array}$ & $\begin{array}{l}\text { Yes } \\
\mathrm{n} / \mathrm{a}\end{array}$ & $\begin{array}{l}\text { Yes } \\
\mathrm{n} / \mathrm{a}\end{array}$ & $\begin{array}{l}\text { Yes } \\
\mathrm{n} / \mathrm{a}\end{array}$ \\
\hline Auditors & Yes & Yes & $\mathrm{n} / \mathrm{a}$ & $\mathrm{n} / \mathrm{a}$ & $\mathrm{n} / \mathrm{a}$ \\
\hline
\end{tabular}




\begin{tabular}{|c|c|c|c|c|c|}
\hline & BNP Paribas & Deutsche Bank & Dexia & Fortis Bank & HBOS \\
\hline Failure or Intervention Date & - & - & $\begin{array}{l}10 / 1 / 2008 \\
10 / 5 / 2011\end{array}$ & $9 / 29 / 2008$ & $\begin{array}{l}9 / 18 / 2008 \\
10 / 8 / 2008\end{array}$ \\
\hline $\begin{array}{l}\text { Initial Disclosure of Subprime } \\
\text { Exposure }\end{array}$ & $\begin{array}{c}\text { 8/13/2007 (press } \\
\text { release: "limited } \\
\text { exposure") } \\
\text { 1/30/2007 (earnings } \\
\text { presentation: revision) }\end{array}$ & $\begin{array}{c}\text { 8/4/2007 (press release: } \\
\text { "not exposed") } \\
\text { 10/3/2007 (press } \\
\text { release: impairments) }\end{array}$ & $\begin{array}{l}\text { 8/6/2007 (press release: } \\
\text { "well protected") }\end{array}$ & $\begin{array}{l}\text { 9/21/2007 (press } \\
\text { release: "no direct } \\
\text { exposure") } \\
\text { 11/8/2007 (press } \\
\text { release: revision) }\end{array}$ & $\begin{array}{c}\text { 12/13/2007 (trading } \\
\text { update) }\end{array}$ \\
\hline $\begin{array}{l}\text { Disclosure of Funding } \\
\text { Structure (2007-Q4) }\end{array}$ & $\begin{array}{c}>/<1 \text { month, } 3 \text { months, } \\
1 \text { year }\end{array}$ & $\begin{array}{c}>/<3 \text { months, } 1 \text { year } \\
\text { (only for liabilities) }\end{array}$ & $\begin{array}{l}>/<3 \text { months, } 1 \text { year } \\
\text { (exakt liquidity gaps) }\end{array}$ & $\begin{array}{l}>/<3 \text { months, } 1 \text { year } \\
\text { (exakt liquidity gaps) }\end{array}$ & $\begin{array}{c}>/<1 \text { month, } 3 \text { months, } \\
1 \text { year (only for } \\
\text { liabilities) }\end{array}$ \\
\hline $\begin{array}{l}\text { Disclosure of Interest Rate } \\
\text { Sensitivity (2007-Q4) }\end{array}$ & $\begin{array}{l}\text { parallel shifts }(+/-100 \\
\text { bps, different maturity } \\
\text { bands) }\end{array}$ & $99 \% \mathrm{VaR}$ for trading & $\begin{array}{l}\text { parallel shifts }(+/-1 \\
\text { bps }), 99 \% \text { VaR for } \\
\text { trading }\end{array}$ & $\begin{array}{l}\text { parallel shifts }(+/-100 \\
\text { bps })\end{array}$ & $\begin{array}{l}\text { parallel shifts }(+/-25 \\
\text { bps })\end{array}$ \\
\hline \multicolumn{6}{|c|}{ Discretionary Accounting Choices: } \\
\hline $\begin{array}{l}\text { Reclassifications of Fair } \\
\text { Value Assets }\end{array}$ & Q4-2008 & Q3-2008, Q4-2008 & Q4-2008 & Q4-2008 & Q4-2008 \\
\hline Transfers to Level 3 & No & No & No & No & No \\
\hline $\begin{array}{l}\text { Gains from Increases in } \\
\text { Own Credit Risk }\end{array}$ & 2007,2008 & 2008 & 2008 & No & No \\
\hline \multicolumn{6}{|l|}{ Corrective Actions: } \\
\hline Dividend Cuts & 2009 & 2009 & 2009 & 2009 & 2009 \\
\hline Last Share Repurchase & $\mathrm{n} / \mathrm{a}$ & $\mathrm{n} / \mathrm{a}$ & $\mathrm{n} / \mathrm{a}$ & $\mathrm{n} / \mathrm{a}$ & $\mathrm{n} / \mathrm{au}$ \\
\hline $\begin{array}{l}\text { Issuance of Equity } \\
\text { (including Preferred Stocks) }\end{array}$ & $\mathrm{n} / \mathrm{a}$ & Q3-2008 & $\mathrm{n} / \mathrm{a}$ & Q3-2007 & Q2-2008, Q3-2008 \\
\hline Government Support & Q4-2008 & $\mathrm{n} / \mathrm{a}$ & Q4-2008 & Q4-2008 & $\mathrm{n} / \mathrm{a}$ \\
\hline \multicolumn{6}{|l|}{ Misstatement Litigation } \\
\hline Bank & $\mathrm{n} / \mathrm{a}$ & Yes & Yes & Yes & Yes (managers) \\
\hline thereof: Public prosecution & $\mathrm{n} / \mathrm{a}$ & Yes (US DOJ) & $\mathrm{n} / \mathrm{a}$ & Yes (Belgium) & Yes (UK FSA) \\
\hline Auditors & $\mathrm{n} / \mathrm{a}$ & Yes & $\mathrm{n} / \mathrm{a}$ & $\mathrm{n} / \mathrm{a}$ & $\mathrm{n} / \mathrm{a}$ \\
\hline
\end{tabular}




\begin{tabular}{|c|c|c|c|c|c|}
\hline & Hypo Real Estate & IKB & Northern Rock & $\begin{array}{l}\text { Royal Bank of } \\
\text { Scotland }\end{array}$ & UBS \\
\hline Failure or Intervention Date & $9 / 28 / 2008$ & $8 / 1 / 2007$ & $\begin{array}{l}9 / 10 / 2007 \\
2 / 22 / 2008\end{array}$ & $10 / 8 / 2008$ & $10 / 16 / 2008$ \\
\hline $\begin{array}{l}\text { Initial Disclosure of Subprime } \\
\text { Exposure }\end{array}$ & $\begin{array}{c}\text { 8/3/2007 (press release: } \\
\text { "no negative impact") } \\
1 / 15 / 2008 \text { (press } \\
\text { release: impairments) }\end{array}$ & $\begin{array}{l}7 / 20 / 2007 \\
7 / 30 / 2007\end{array}$ & $\begin{array}{l}\text { before } 2007 \text { (for } \\
\text { securitizations) } \\
\text { 9/13/2007 (press } \\
\text { statement: CDO } \\
\text { exposure) }\end{array}$ & $\begin{array}{l}\text { 12/6/2007 (trading } \\
\text { update) }\end{array}$ & $\begin{array}{l}\text { 10/1/2007 (earnings } \\
\text { announcement: } \\
\text { impairments) }\end{array}$ \\
\hline $\begin{array}{l}\text { Disclosure of Funding } \\
\text { Structure (2007-Q4) }\end{array}$ & $\begin{array}{l}>/<3 \text { months, } 1 \text { year } \\
\text { (dispersed over report) }\end{array}$ & $\begin{array}{c}>/<1 \text { month, } 3 \text { months, } \\
1 \text { year (only for } \\
\text { liabilities) }\end{array}$ & $\begin{array}{c}>/<3 \text { months, } 6 \\
\text { months, } 1 \text { year } \\
\text { (reference to exakt } \\
\text { liquidity gaps) }\end{array}$ & $\begin{array}{c}>/<1 \text { months, } 1 \text { year } \\
\text { (reference to } 1-\text { month } \\
\text { liquidity gaps) }\end{array}$ & $\begin{array}{c}>/<1 \text { month, } 3 \text { months, } \\
1 \text { year }\end{array}$ \\
\hline $\begin{array}{l}\text { Disclosure of Interest Rate } \\
\text { Sensitivity (2007-Q4) }\end{array}$ & $99 \% \mathrm{VaR}$ & $99.8 \% \mathrm{VaR}$ & $\begin{array}{c}\text { parallel shifts }(+/-100 \\
\text { bps })\end{array}$ & $\begin{array}{c}\text { parallel shifts }(+/-100 \\
\text { bps), VaR }\end{array}$ & $99 \% \mathrm{VaR}$ \\
\hline \multicolumn{6}{|l|}{ Discretionary Accounting Choices: } \\
\hline $\begin{array}{l}\text { Reclassifications of Fair } \\
\text { Value Assets }\end{array}$ & Q3-2008, Q4-2008 & No & Q4-2008 & Q4-2008 & Q4-2008 \\
\hline Transfers to Level 3 & No & No & No & No & No \\
\hline $\begin{array}{l}\text { Gains from Increases in } \\
\text { Own Credit Risk }\end{array}$ & No & 2007,2008 & No & 2007,2008 & 2007,2008 \\
\hline \multicolumn{6}{|l|}{ Corrective Actions: } \\
\hline Dividend Cuts & 2009 & 2008 & 2008 & 2009 & 2009 \\
\hline Last Share Repurchase & $\mathrm{n} / \mathrm{a}$ & $\mathrm{n} / \mathrm{a}$ & $\mathrm{n} / \mathrm{a}$ & $\mathrm{n} / \mathrm{a}$ & 2007 \\
\hline $\begin{array}{l}\text { Issuance of Equity } \\
\text { (including Preferred Stocks) }\end{array}$ & Q4-2007, Q3-2008 & $\mathrm{n} / \mathrm{a}$ & $\mathrm{n} / \mathrm{a}$ & $\mathrm{n} / \mathrm{a}$ & Q1/2008, Q2/2008 \\
\hline Government Support & Q3-2008, Q4-2008 & Q3-2007 & Q3-2007 & Q4-2008 & Q4-2008 \\
\hline \multicolumn{6}{|l|}{ Misstatement Litigation } \\
\hline Bank & Yes (managers) & Yes & Yes (managers) & Yes & Yes \\
\hline thereof: Public prosecution & Yes (Germany) & Yes (Germany) & Yes (UK FSA) & $\mathrm{n} / \mathrm{a}$ & Yes (US SEC) \\
\hline Auditors & $\mathrm{n} / \mathrm{a}$ & $\mathrm{n} / \mathrm{a}$ & $\mathrm{n} / \mathrm{a}$ & $\mathrm{n} / \mathrm{a}$ & $\mathrm{n} / \mathrm{a}$ \\
\hline
\end{tabular}


The table summarizes information about disclosures, asset impairments, other reporting choices, corrective actions and subsequent misstatement litigation during the 2007-08 crisis. Panel A presents the information for ten US banks. Panel B presents the information for ten European banks. We choose this sample based on bank size and financial difficulties during the crisis. We have collected the information about disclosures, impairments, discretionary accounting choices, and corrective actions from all SEC filings (when available; for U.S. banks) and from all reports available via a bank's website or other publicly available sources between 2006-Q4 and 2008-Q4. We have collected the information about litigation from the Audit Analytics Litigation Database, Stanford Law School's Securities Class Action Clearinghouse, and Bloomberg's Company Legal Search. We also screen the list of enforcement actions published by the SEC. We tabulate whether a bank was involved in a legal case that directly relates to misstatements in the financial reporting and disregard all other legal cases (e.g., about securities sales). We highlight if the legal case targets the bank managers, rather than the bank. We separately note cases where the bank is subject to prosecution by a public institution (e.g., a regulator, Attorney General) rather than sued by investors. We also tabulate whether bank auditors were involved in such a legal case. 
Table 2: Market Reactions to Bank Disclosures and Economy-wide Events during the Crisis

\begin{tabular}{|c|c|c|c|c|c|c|c|c|}
\hline \multirow[b]{3}{*}{ Bank Disclosure } & \multicolumn{4}{|c|}{$\Delta 5 \mathrm{Y}$ CDS Spreads } & \multicolumn{4}{|c|}{ Daily Share Return } \\
\hline & (1) & (2) & (3) & (4) & (5) & (6) & (7) & (8) \\
\hline & & $\begin{array}{c}0.0000 \\
(0.21)\end{array}$ & & & & $\begin{array}{c}-0.0033 \\
(-0.94)\end{array}$ & & \\
\hline First Bank Disclosure & & & $\begin{array}{c}-0.0001 \\
(-0.70)\end{array}$ & & & & $\begin{array}{c}0.0001 \\
(0.02)\end{array}$ & \\
\hline First 10Q/10K Disclosure & & & & $\begin{array}{c}0.0004 * * * \\
(2.67)\end{array}$ & & & & $\begin{array}{c}-0.0125^{* * *} \\
(-2.65)\end{array}$ \\
\hline Economy-wide Events: & & & & & & & & \\
\hline $2 / 7 / 2007$ & -0.0000 & -0.0000 & -0.0000 & -0.0000 & -0.0008 & -0.0009 & -0.0008 & -0.0010 \\
\hline HSBC reports losses & $(-0.21)$ & $(-0.20)$ & $(-0.23)$ & $(-0.1$ & $(-0.19)$ & $(-0.22)$ & $(-0.19)$ & $(-0.25)$ \\
\hline $2 / 27 / 2007$ & 0.0002 & 0.0002 & 0.0002 & 0.0002 & $-0.0165 * * *$ & $-0.0166^{* * *}$ & $-0.0165 * * *$ & $k^{*}-0.0167 * * *$ \\
\hline Freddie Mac announces problems & $(1.11)$ & $(1.12)$ & $(1.09)$ & $(1.17)$ & $(-4.18)$ & $(-4.21)$ & $(-4.18)$ & $(-4.24)$ \\
\hline $3 / 12 / 2007$ & 0.0001 & 0.0001 & 0.0001 & 0.0001 & $-0.0133 * * *$ & $-0.0133 * * *$ & $-0.0133 * * *$ & $-0.0134 * * *$ \\
\hline New Century Financial shares suspended & $(0.80)$ & $(0.81)$ & $(0.80)$ & $(0.83)$ & $(-3.39)$ & $(-3.40)$ & $(-3.39)$ & $(-3.41)$ \\
\hline $5 / 2 / 2007$ & -0.0001 & -0.0001 & -0.0001 & -0.0( & 0.0028 & 0.0028 & 0.0028 & 0.0028 \\
\hline Shutdown of UBS Hedge Fund & $(-0.50)$ & $(-0.50)$ & $(-0.50)$ & $(-0.50)$ & $(0.70)$ & $(0.70)$ & $(0.70)$ & $(0.70)$ \\
\hline $6 / 7 / 2007$ & 0.0000 & 0.0000 & 0.0000 & 0.0000 & -0.0058 & -0.0058 & -0.0058 & -0.0058 \\
\hline BS Hedge Funds stop redemptions & $(0.24)$ & $(0.2$ & $(0.2$ & $(0.2$ & $(-1.46)$ & $(-1.46)$ & 46) & $(-1.46)$ \\
\hline 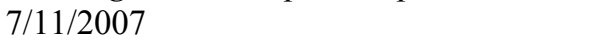 & 0.0002 & 0.0002 & 0.00 & 0.00 & -0.0 & -0.0 & -0.0004 & -0.0004 \\
\hline ngrades for 612 securities & $(1.4$ & $(1.43)$ & & & $(-0$. & $(-0$ & $(-0$ & $(-0$. \\
\hline $7 / 17 / 2$ & 0.0002 & 0.0002 & 0.00 & 0.00 & $-0.0094 * *$ & -0.005 & $-0.0094 * *$ & $-0.0094 * *$ \\
\hline s by BS Hedge Funds & $(1.22)$ & $(1.22)$ & $(1.22)$ & $(1.2$ & $(-2.37)$ & $(-2.37)$ & $(-2.37)$ & $(-2.38)$ \\
\hline $7 / 20 / 2007$ & $0.0003 * *$ & $0.0003 * *$ & $0.0003 * *$ & $0.0003^{* *}$ & $-0.0106 * *$ & $-0.0106 * *$ & $-0.0106^{* *}$ & $-0.0106^{* *}$ \\
\hline Bernanke warning & $(2.28)$ & $(2.28)$ & $(2.28)$ & $(2.29)$ & $(-2.55)$ & $(-2.55)$ & $(-2.55)$ & $(-2.55)$ \\
\hline $7 / 24 / 2007$ & $0.0003 * *$ & $0.0003 * *$ & $0.0003 * *$ & $0.0003 * *$ & -0.0064 & -0.0064 & -0.0064 & -0.0064 \\
\hline ide profit warning & (2.19) & (2.19) & (2.19) & $(2.2$ & $(-1.54)$ & $(-1.54)$ & $(-1.54)$ & $(-1.54)$ \\
\hline 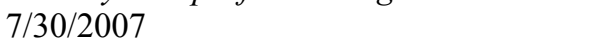 & -0.00 & -0.0002 & -0.00 & -0.0 & -0.0032 & -0.0032 & -0.0032 & -0.0032 \\
\hline warning & 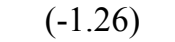 & $(-1.26)$ & $(-1$. & & $(-0.77)$ & $(-0.77)$ & $(-0.77)$ & $(-0.77)$ \\
\hline $8 / 1 / 2007$ & -0.00 & -0.0001 & -0.0001 & -0.0 & $-0.0120 * * *$ & $-0.0120 * * *$ & $-0.0120 * * *$ & $-0.0120 * * *$ \\
\hline SEC letter to Lehman & $(-1.03)$ & $(-1.03)$ & $(-1.03)$ & & $(-2.89)$ & $(-2.89)$ & $(-2.89)$ & $(-2.90)$ \\
\hline $8 / 6 / 2007$ & $0.0004 * * *$ & $0.0004 * * *$ & $0.0004 * * *$ & $0.0004 * * *$ & 0.0048 & 0.0048 & & 0.0048 \\
\hline AHMI bankruptcy & $(2.80)$ & $(2.80)$ & $(2.80)$ & $(2.80)$ & $(1.21)$ & $(1.21)$ & $(1.21)$ & $(1.21)$ \\
\hline $8 / 9 / 2007$ & -0.0000 & -0.0000 & -0.0000 & -0.0000 & $-0.0104 * * *$ & $-0.0104 * * *$ & $-0.0104 * * *$ & $-0.0104 * * *$ \\
\hline ree funds & $(-0.02)$ & $(-0.02)$ & $(-0.02)$ & & $(-2.64)$ & $(-2.64)$ & & \\
\hline $8 / 21 / 2007$ & $-0.0005 * * *$ & $-0.0005^{* * *}$ & $-0.0005 * * *$ & $*-0.0005$ & -0.0018 & -0.0018 & -0.0018 & -0.0018 \\
\hline e in US subprime defaults & $(-3.88)$ & $(-3.88)$ & $(-3.88)$ & & $(-0.44)$ & $(-0.44)$ & $(-0.44)$ & $(-0.45)$ \\
\hline $8 / 28 / 2007$ & $0.0004 * * *$ & $0.0004 * * *$ & $0.0004 * * *$ & $0.0004 * * *$ & $-0.0160 * * *$ & $-0.0160 * * *$ & $-0.0160 * * *$ & $-0.0160 * * *$ \\
\hline SachsenLB failure & $(2.95)$ & $(2.95)$ & $(2.95)$ & & $(-4.06)$ & $(-4.06)$ & $(-4.06)$ & $(-4.06)$ \\
\hline 9/13/2007 & 0.0000 & 0.0000 & 0.0000 & 0.0000 & $0.0017 *$ & 0.0016 & $0.0017 *$ & 0.0014 \\
\hline Northern Rock failure & $(0.24)$ & $(0.27)$ & $(0.16)$ & $(0.49)$ & $(1.74)$ & $(1.60)$ & $(1.73)$ & $(1.50)$ \\
\hline $11 / 20 / 2007$ & $0.0010 * * *$ & $0.0010 * * *$ & $0.0010^{* * *}$ & $0.0010 * * *$ & $-0.0242 * * *$ & $-0.0244 * * *$ & $-0.0242 * * *$ & $*-0.0245^{* * *}$ \\
\hline Freddie Mac announces $\$ 2$ bn losses & $(6.84)$ & & & & $(-6.14)$ & $(-6.17)$ & & \\
\hline $12 / 3 / 2007$ & -0.0001 & -0.0001 & -0.0001 & -0.0001 & 0.0012 & 0.0011 & 0.0012 & 0.0010 \\
\hline Moody's downgrades for $\$ 116 \mathrm{bn}$ of debt & $(-0.96)$ & $(-0.95)$ & & & $(0.36)$ & $(0.33)$ & $(0.36)$ & $(0.29)$ \\
\hline $12 / 13 / 2007$ & 0.0001 & 0.0001 & & 0.00 & $-0.0121 * * *$ & $-0.0120 * * *$ & $-0.0121 * * *$ & $k_{-0} 0.0114 * * *$ \\
\hline Fed announces TAF program & $(0.92)$ & $(0.91)$ & $(0.90)$ & $(0.65)$ & $(-3.53)$ & $(-3.49)$ & $(-3.52)$ & $(-3.31)$ \\
\hline Bank FE & $\mathrm{Ye}$ & Yes & Yes & Yes & Yes & Yes & Yes & Yes \\
\hline $\mathrm{R}^{2}$ & 0.048 & 0.048 & & & & & & \\
\hline \# Observations & 2,040 & 2,040 & 2,040 & 2,040 & 2,470 & 2,470 & 2,470 & 2,470 \\
\hline
\end{tabular}


The table presents the results of OLS regressions of the daily change in CDS spreads (columns [1] to [4]) and daily share returns (columns [5] to [8]) on indicator variables for the 3-day time window [-1,+1] around bank disclosures and economy-wide events during the crisis. CDS spreads are from contracts denominated in USD, with modified restructuring clauses, and of senior unsecured debts. The daily change in CDS spreads is measured in basis points (source: IHS Markit). The daily share return is the raw return and also measured in basis points (source: CRSP). Bank Disclosure is any disclosure event for which a bank provides information about risk exposures to the subprime mortgage market. First Bank Disclosure represents the earliest of these events for each one of our sample banks (irrespective of the document in which the disclosure occurs). First 10Q/10K Disclosure represents the earliest of these events in which the disclosure is part of the bank's 10-Q or 10-K filing. The economy-wide events are major crisis-related news events, which we selected from the Factiva Global News Database. Our sample comprises daily observations of spread changes and returns for the 10 U.S. sample banks (Table 1) during calendar year 2007. The table reports OLS coefficient estimates and (in parentheses) $t$-statistics based on robust standard errors. ${ }^{* * *}, * *$, and $*$ indicate statistical significance at the $1 \%, 5 \%$, and $10 \%$ levels (two-tailed). 
Table 3: Reported Loan Losses of U.S. Banks and Market Expectations

Panel A: Loss Forecasts for Individual Loan Portfolios

\begin{tabular}{|c|c|c|c|c|c|c|c|c|c|c|c|c|c|c|}
\hline \multirow[b]{3}{*}{$\begin{array}{l}\text { Bank of } \\
\text { America }\end{array}$} & \multicolumn{2}{|c|}{ Loans held } & \multicolumn{2}{|c|}{$\begin{array}{l}\text { Reported loan } \\
\text { losses }\end{array}$} & \multicolumn{7}{|c|}{ Estimate for market expectation } & \multicolumn{3}{|c|}{ Future net charge-offs } \\
\hline & $\begin{array}{c}\text { Net book } \\
\text { value } \\
\text { (amortiz } \\
\text { ed } \\
\text { cost) } \\
\text { [A] }\end{array}$ & $\begin{array}{c}\text { Fair } \\
\text { value } \\
{[\mathrm{B}]}\end{array}$ & $\begin{array}{l} \\
\text { Allowance } \\
\text { for loan } \\
\text { and lease } \\
\text { losses } \\
{[\mathrm{C}]} \\
\end{array}$ & $\begin{array}{c}\text { Total } \\
\text { implied } \\
\text { loss } \\
{[\mathrm{D}]=} \\
([\mathrm{A}]- \\
[\mathrm{B}]) \\
+[\mathrm{C}] \\
\end{array}$ & $\begin{array}{c}\text { SCAP } \\
\text { prediction } \\
{[\mathrm{E}]} \\
\end{array}$ & $\begin{array}{c}\text { Citigroup } \\
\text { report } \\
{[\mathrm{F}]}\end{array}$ & $\begin{array}{c}\text { Goldman } \\
\text { Sachs } \\
\text { report } \\
{[\mathrm{G}]}\end{array}$ & $\begin{array}{c}\mathrm{S} \& \mathrm{P} \\
\text { report } \\
{[\mathrm{H}]} \\
\end{array}$ & $\begin{array}{c}\text { Median } \\
\text { estimate } \\
{[\mathrm{I}]}\end{array}$ & $\begin{array}{c}\text { Median } \\
\text { estimate / } \\
\text { Loan loss } \\
\text { allowance } \\
{[\mathrm{J}]=} \\
{[\mathrm{I}] /[\mathrm{C}]} \\
\end{array}$ & $\begin{array}{c}\text { Median } \\
\text { estimate / } \\
\text { Implied } \\
\text { loss } \\
{[\mathrm{K}]=} \\
{[\mathrm{I}] /[\mathrm{D}]} \\
\end{array}$ & $\begin{array}{c}\text { Net } \\
\text { charge-offs } \\
2009-2010 \\
{[\mathrm{M}]} \\
\end{array}$ & $\begin{array}{c}\text { Net } \\
\text { charge-offs } \\
2009-2011 \\
{[\mathrm{~N}]}\end{array}$ & $\begin{array}{c}\text { Median } \\
\text { estimate / } \\
\text { Net } \\
\text { charge-offs } \\
{[\mathrm{O}]=} \\
{[\mathrm{I}] /[\mathrm{N}]} \\
\end{array}$ \\
\hline & 866.2 & 841.6 & 23.1 & 47.7 & 104.1 & 83.8 & 83.3 & 74.6 & 83.6 & 3.62 & 1.75 & 68.0 & 89.7 & 0.93 \\
\hline Citigroup & 660.9 & 642.7 & 29.6 & 47.8 & 79.4 & NA & 63.5 & 50.0 & 63.5 & 2.15 & 1.33 & 65.8 & 87.7 & 0.72 \\
\hline JP Morgan & 721.7 & 700.0 & 23.2 & 44.9 & 79.3 & 111.9 & 62.3 & 54.5 & 70.8 & 3.05 & 1.58 & 46.6 & 58.9 & 1.20 \\
\hline Wells Fargo & 849.6 & 835.5 & 21.1 & 35.2 & 74.3 & 51.5 & 65.9 & 59.2 & 62.6 & 2.96 & 1.78 & 35.9 & 47.2 & 1.32 \\
\hline BB\&T Bank & 94.4 & 96.3 & 1.6 & -0.3 & 8.5 & NA & 7.6 & 7.9 & 7.9 & 5.03 & NA & 4.3 & 6.0 & 1.33 \\
\hline Capital One & 96.5 & 86.4 & 4.5 & 14.6 & 13.0 & NA & 11.8 & 10.1 & 11.8 & 2.61 & 0.81 & 11.2 & 15.0 & 0.79 \\
\hline $\begin{array}{l}\text { Fifth Third } \\
\text { Bank }\end{array}$ & 81.3 & 74.2 & 2.8 & 9.9 & 9.2 & 5.4 & 5.7 & 6.5 & 6.1 & 2.19 & 0.62 & 4.9 & 6.1 & 1.00 \\
\hline KeyCorp & 74.7 & 65.9 & 1.8 & 10.6 & 6.5 & 3.6 & 4.3 & 5.5 & 4.9 & 2.71 & 0.46 & 4.1 & 4.8 & 1.03 \\
\hline PNC Fin. & 165.1 & 162.2 & 3.9 & 6.9 & 17.4 & 10.4 & 11.7 & 12.1 & 11.9 & 3.04 & 1.73 & 5.6 & 7.3 & 1.63 \\
\hline $\begin{array}{l}\text { Regions } \\
\text { Financial }\end{array}$ & 94.9 & 79.9 & 1.8 & 16.8 & 9.0 & NA & 5.7 & 6.9 & 6.9 & 3.79 & 0.41 & 5.0 & 7.0 & 0.99 \\
\hline SunTrust & 124.6 & 110.9 & 2.4 & 16.1 & 11.8 & NA & 8.7 & 8.9 & 8.9 & 3.78 & 0.55 & 6.1 & 8.1 & 1.09 \\
\hline U.S. Bancorp & 181.7 & 180.3 & 3.5 & 4.9 & 14.6 & 8.2 & 14.8 & 14.3 & 14.5 & 4.11 & 2.94 & 8.0 & 10.9 & 1.33 \\
\hline Comerica & 49.7 & 50.9 & 0.8 & -0.3 & NA & 2.0 & 3.1 & 3.5 & 3.1 & 4.00 & NA & 1.4 & 1.8 & 1.75 \\
\hline First Horizon & 20.4 & 18.8 & 0.8 & 2.5 & NA & 1.2 & 1.3 & 1.5 & 1.3 & 1.51 & 0.51 & 1.4 & 1.7 & 0.76 \\
\hline M\&T Bank & 48.2 & 47.4 & 0.8 & 1.6 & NA & 2.1 & 3.3 & 3.6 & 3.3 & 4.16 & 2.11 & 0.9 & 1.1 & 2.91 \\
\hline Average & 275.3 & 266.2 & 8.1 & 17.3 & 35.6 & 28.0 & 23.5 & 21.3 & 24.1 & 3.25 & 1.27 & 18.0 & 23.5 & 1.25 \\
\hline Median & 96.5 & 96.3 & 2.8 & 10.6 & 13.8 & 6.8 & 8.7 & 8.9 & 8.9 & 3.05 & 1.33 & 5.6 & 7.3 & 1.09 \\
\hline
\end{tabular}


Panel B: Reported Loss Estimates, Market Expectations, and Incentives

\begin{tabular}{|c|c|c|c|c|c|c|c|c|c|c|c|c|}
\hline \multirow{3}{*}{$\begin{array}{c}\text { Dependent Variable: } \\
\text { Variables of Interest: }\end{array}$} & \multicolumn{6}{|c|}{ Loss Allowance / Gross Loans } & \multicolumn{6}{|c|}{ Disclosed Fair Value Loss / Gross Loans } \\
\hline & $(1)$ & $(2)$ & $(3)$ & $(4)$ & $(5)$ & $(6)$ & $(7)$ & $(8)$ & $(9)$ & $(10)$ & $(11)$ & $(12)$ \\
\hline & & & & & & & & & & & & \\
\hline Market Estimate & $\begin{array}{c}0.128 * * * \\
(13.75)\end{array}$ & & $\begin{array}{l}0.135 * * * \\
(12.09)\end{array}$ & $\begin{array}{l}0.123 * * * \\
(14.30)\end{array}$ & $\begin{array}{l}0.122 * * * \\
(14.71)\end{array}$ & $\begin{array}{c}0.123 * * * \\
(14.54)\end{array}$ & $\begin{array}{l}0.007 \\
(0.18)\end{array}$ & & $\begin{array}{l}-0.011 \\
(-0.23)\end{array}$ & $\begin{array}{l}0.009 \\
(0.27)\end{array}$ & $\begin{array}{l}-0.009 \\
(-0.20)\end{array}$ & $\begin{array}{l}-0.010 \\
(-0.21)\end{array}$ \\
\hline $\begin{array}{l}\text { Future Charge-Offs } \\
(2009-11)\end{array}$ & & $\begin{array}{c}0.055^{* * *} \\
(2.83)\end{array}$ & $\begin{array}{c}0.048 * * * \\
(2.62)\end{array}$ & $\begin{array}{c}0.039 * * \\
(2.28)\end{array}$ & $\begin{array}{c}0.041 * * \\
(2.45)\end{array}$ & $\begin{array}{c}0.040 * * \\
(2.37)\end{array}$ & & $\begin{array}{l}0.118 \\
(1.03)\end{array}$ & $\begin{array}{l}0.120 \\
(0.94)\end{array}$ & $\begin{array}{l}0.120 \\
(1.08)\end{array}$ & $\begin{array}{l}0.118 \\
(1.01)\end{array}$ & $\begin{array}{l}0.119 \\
(1.02)\end{array}$ \\
\hline $\begin{array}{l}\% \text { Residential } \\
\text { Mortgage Loans }\end{array}$ & & & $\begin{array}{l}-0.005 \\
(-1.15)\end{array}$ & & & & & & $\begin{array}{l}0.007 \\
(0.26)\end{array}$ & & & \\
\hline$\%$ CRE Loans & & & $\begin{array}{c}-0.008 * * \\
(-2.29)\end{array}$ & & & & & & $\begin{array}{l}-0.000 \\
(-0.02)\end{array}$ & & & \\
\hline \% C\&I Loans & & & $\begin{array}{l}0.003 \\
(0.69)\end{array}$ & & & & & & $\begin{array}{l}-0.011 \\
(-0.35)\end{array}$ & & & \\
\hline $\begin{array}{l}\text { Forward-Looking 8-K } \\
\text { Disclosure (Dummy) }\end{array}$ & & & & $\begin{array}{l}0.001 \\
(0.35)\end{array}$ & & & & & & $\begin{array}{l}0.060^{*} \\
(1.80)\end{array}$ & & \\
\hline Low Capital Ratio & & & & & $\begin{array}{c}-0.002 * * * \\
(-2.60)\end{array}$ & & & & & & $\begin{array}{l}0.001 \\
(0.34)\end{array}$ & \\
\hline Low Tier 1 Ratio & & & & & & $\begin{array}{l}-0.001 * \\
(-1.74)\end{array}$ & & & & & & $\begin{array}{l}0.000 \\
(0.03)\end{array}$ \\
\hline Control Variables: & & & & & & & & & & & & \\
\hline Current Charge-Offs & $\begin{array}{c}0.217 * * \\
(2.58)\end{array}$ & $\begin{array}{c}0.175^{*} \\
(1.96)\end{array}$ & $\begin{array}{c}0.165 * * \\
(2.00)\end{array}$ & $\begin{array}{c}0.177 * * \\
(2.05)\end{array}$ & $\begin{array}{c}0.177 * * \\
(2.09)\end{array}$ & $\begin{array}{c}0.174 * * \\
(2.04)\end{array}$ & $\begin{array}{l}0.338 \\
(0.87)\end{array}$ & $\begin{array}{l}0.216 \\
(0.57)\end{array}$ & $\begin{array}{l}0.227 \\
(0.59)\end{array}$ & $\begin{array}{l}0.170 \\
(0.45)\end{array}$ & $\begin{array}{l}0.216 \\
(0.57)\end{array}$ & $\begin{array}{l}0.217 \\
(0.56)\end{array}$ \\
\hline $\begin{array}{l}\text { Loans Past Due \& Not } \\
\text { Accruing }\end{array}$ & $\begin{array}{c}0.130 * * * \\
(5.17)\end{array}$ & $\begin{array}{c}0.115 * * * \\
(3.77)\end{array}$ & $\begin{array}{l}0.110 * * * \\
(3.76)\end{array}$ & $\begin{array}{c}0.108 * * * \\
(3.85)\end{array}$ & $\begin{array}{c}0.105 * * * \\
(3.82)\end{array}$ & $\begin{array}{c}0.107 * * * \\
(3.89)\end{array}$ & $\begin{array}{c}0.404 * * \\
(2.36)\end{array}$ & $\begin{array}{c}0.336^{*} \\
(1.90)\end{array}$ & $\begin{array}{c}0.331^{*} \\
(1.85)\end{array}$ & $\begin{array}{c}0.341 * * \\
(2.00)\end{array}$ & $\begin{array}{c}0.339 * \\
(1.91)\end{array}$ & $\begin{array}{c}0.336^{*} \\
(1.89)\end{array}$ \\
\hline Size & $\begin{array}{c}0.001 * * * \\
(4.34)\end{array}$ & $\begin{array}{c}0.001 * * * \\
(3.55)\end{array}$ & $\begin{array}{l}0.000 \\
(1.59)\end{array}$ & $\begin{array}{c}0.001 * * * \\
(3.92)\end{array}$ & $\begin{array}{c}0.001 * * * \\
(3.45)\end{array}$ & $\begin{array}{c}0.001 * * * \\
(3.78)\end{array}$ & $\begin{array}{c}0.009 * * * \\
(4.04)\end{array}$ & $\begin{array}{c}0.009 * * * \\
(3.94)\end{array}$ & $\begin{array}{c}0.009 * * * \\
(3.91)\end{array}$ & $\begin{array}{c}0.007 * * * \\
(3.60)\end{array}$ & $\begin{array}{c}0.009 * * * \\
(4.13)\end{array}$ & $\begin{array}{c}0.009 * * * \\
(4.02)\end{array}$ \\
\hline RWA / Total Assets & $\begin{array}{l}-0.001 \\
(-0.37)\end{array}$ & $\begin{array}{l}-0.004 \\
(-1.04)\end{array}$ & $\begin{array}{l}-0.003 \\
(-0.86)\end{array}$ & $\begin{array}{l}-0.002 \\
(-0.81)\end{array}$ & $\begin{array}{l}-0.001 \\
(-0.22)\end{array}$ & $\begin{array}{l}-0.001 \\
(-0.22)\end{array}$ & $\begin{array}{l}0.013 \\
(0.55)\end{array}$ & $\begin{array}{l}0.009 \\
(0.37)\end{array}$ & $\begin{array}{l}0.017 \\
(0.64)\end{array}$ & $\begin{array}{l}-0.011 \\
(-0.44)\end{array}$ & $\begin{array}{l}0.008 \\
(0.31)\end{array}$ & $\begin{array}{l}0.009 \\
(0.35)\end{array}$ \\
\hline Return on Assets & $\begin{array}{l}-0.037 \\
(-1.12)\end{array}$ & $\begin{array}{l}-0.024 \\
(-0.72)\end{array}$ & $\begin{array}{l}-0.044 \\
(-1.22)\end{array}$ & $\begin{array}{l}-0.032 \\
(-0.92)\end{array}$ & $\begin{array}{l}-0.031 \\
(-0.87)\end{array}$ & $\begin{array}{l}-0.031 \\
(-0.88)\end{array}$ & $\begin{array}{l}-0.230 \\
(-1.21)\end{array}$ & $\begin{array}{l}-0.214 \\
(-1.14)\end{array}$ & $\begin{array}{l}-0.204 \\
(-1.07)\end{array}$ & $\begin{array}{l}-0.224 \\
(-1.25)\end{array}$ & $\begin{array}{l}-0.214 \\
(-1.14)\end{array}$ & $\begin{array}{l}-0.213 \\
(-1.14)\end{array}$ \\
\hline $\begin{array}{l}\text { Deposits / Total } \\
\text { Liabilities }\end{array}$ & $\begin{array}{l}-0.004 \\
(-1.13)\end{array}$ & $\begin{array}{l}-0.005 \\
(-1.19)\end{array}$ & $\begin{array}{l}-0.004 \\
(-1.05)\end{array}$ & $\begin{array}{l}-0.005 \\
(-1.29)\end{array}$ & $\begin{array}{l}-0.005 \\
(-1.44)\end{array}$ & $\begin{array}{l}-0.005 \\
(-1.41)\end{array}$ & $\begin{array}{l}-0.000 \\
(-0.01)\end{array}$ & $\begin{array}{l}-0.002 \\
(-0.07)\end{array}$ & $\begin{array}{l}-0.001 \\
(-0.05)\end{array}$ & $\begin{array}{l}-0.004 \\
(-0.16)\end{array}$ & $\begin{array}{l}-0.001 \\
(-0.05)\end{array}$ & $\begin{array}{l}-0.002 \\
(-0.07)\end{array}$ \\
\hline Net Interest Margin & $\begin{array}{l}0.109 * \\
(1.84) \\
\end{array}$ & $\begin{array}{c}0.122 * * \\
(2.06) \\
\end{array}$ & $\begin{array}{l}0.075 \\
(1.26) \\
\end{array}$ & $\begin{array}{l}0.108^{*} \\
(1.82) \\
\end{array}$ & $\begin{array}{l}0.098^{*} \\
(1.66) \\
\end{array}$ & $\begin{array}{l}0.098 \\
(1.64) \\
\end{array}$ & $\begin{array}{l}0.364 \\
(1.11) \\
\end{array}$ & $\begin{array}{l}0.355 \\
(1.07) \\
\end{array}$ & $\begin{array}{l}0.363 \\
(1.02) \\
\end{array}$ & $\begin{array}{l}0.503 \\
(1.35) \\
\end{array}$ & $\begin{array}{l}0.364 \\
(1.10) \\
\end{array}$ & $\begin{array}{l}0.358 \\
(1.07) \\
\end{array}$ \\
\hline Constant & Yes & Yes & Yes & Yes & Yes & Yes & Yes & Yes & Yes & Yes & Yes & Yes \\
\hline $\mathrm{R}^{2}$ & 0.632 & 0.521 & 0.668 & 0.645 & 0.654 & 0.649 & 0.245 & 0.248 & 0.250 & 0.317 & 0.249 & 0.248 \\
\hline \# Observations & 237 & 237 & 237 & 237 & 237 & 237 & 237 & 237 & 237 & 237 & 237 & 237 \\
\hline
\end{tabular}


The table compares loan losses reported by U.S. banks for fiscal year 2008 and concurrent loan loss expectations by market participants (early 2009). Panel A presents the estimates for a sample of 15 banks for which individual loan loss estimates are available in either the 2009 Citigroup report ("US Banks: Assessing Risk/Reward under Various Stress Test Scenarios”, published on March 2, 2009) or the Federal Reserve System's 2009 Supervisory Capital Assessment Program (SCAP, published on May 7, 2009). We use accounting data from regulatory FR Y-9C filings for the Net book value (amortized cost) of banks' total loans (2008Q4), the Allowance for loan and lease losses (2008-Q4), and Net charge-offs (2009-Q4, 2010-Q4, and 2011-Q4). We use disclosure data from banks' 10-K filings with the SEC for the disclosed Fair value of the loan portfolio (2008-Q4). Total implied loss is the loan loss allowance (column [C]) plus the difference between the net book value and the disclosed fair value of the loan portfolio (column [A] minus column [B]). We use bank-specific loan loss estimates from the Federal Reserve System's 2009 SCAP (SCAP prediction) and the 2009 Citigroup report (Citigroup Report). We derive additional market estimates from the 2009 Goldman Sachs report ("United States: Financial Services - As Mortgage Loss Estimates Continue to Rise, Further Policy Response Likely to Follow", published on February 26, 2009; Goldman Sachs Report) and the 2009 Standard \& Poor's report ("What Stress Tests Reveal About U.S. Banks' Capital Needs", published on May 1, 2009; S\&P Report), for which we predict bank-specific losses by multiplying the projected loss rates for each loan category by the loans that a bank is holding in this category as reported in the FR Y-9C filing for the fourth quarter of 2008. We use the estimated lifetime losses from the Goldman Sachs Report and the estimated 2 -year losses from the base scenario in the S\&P Report. The estimates cover an average of 88.7\% (Goldman Sachs) and 97.8\% (S\&P) of the loan portfolios of our sample banks and thus provide a lower bound for the total market estimate. The Median estimate (column [I]) represents the median over all available forecasts. Column [J] reports the ratio of the Median Estimate to the Allowance for loan and lease losses (2008-Q4). Column [K] reports the ratio of the Median Estimate to the Total implied loss (2008-Q4). Column [O] reports the ratio of the Median Estimate to the sum of the Net charge-offs from 2009 to 2011. Panel B presents the results of OLS regressions of the recognized loss allowance and the disclosed fair value losses on different proxies for market estimates and reporting incentives for a sample of 237 publicly listed US bank holding companies. The dependent variable in columns (1) to (6) is the ratio of the allowance for loan and lease losses to the gross book value of the loan portfolio (Loss Allowance / Gross Loans). The dependent variable in columns (7) to (12) is the ratio of disclosed fair value losses of the loan portfolio to the portfolio's gross book value (Disclosed Fair Value Loss / Gross Loans). Market Estimate is the average estimate from the Goldman Sachs Report and the S\&P Report computed as in Panel A. Future Charge-Offs (2009-11) is the sum of the net charge-offs from 2009 to 2011. \% Residential Mortgage Loans is the percentage of the loan portfolio held in residential mortgages (FR Y-9C items bhdm5367, bhdm5368, and bhdm1460). \% CRE Loans is the percentage of the loan portfolio held in commercial real estate (FR Y-9C items bhckf158, bhckf159, bhckf160, and bhckf161). \% C\&I Loans is the percentage of the loan portfolio held in commercial and industrial loans (FR Y-9C items bhck1763 and bhck1764). Forward-Looking 8-K Disclosure is an indicator variable that takes a value of 1 if the bank provides a forward-looking loan loss disclosure in any 8 -K filing with the SEC over the period from 2007 to 2008 (as defined in Figure 3), 0 otherwise. Low Capital Ratio (Low Tier 1 Ratio) is an indicator variable that takes a value of 1 if the bank's total capital ratio (tier 1 ratio) as of December 31, 2008, is in the lowest quartile of all 237 sample banks, 0 otherwise. Current Charge-Offs is the ratio of net-charge-offs in financial year 2008 to the gross book value of the loan portfolio. Loans Past Due \& Not Accruing is the ratio of a bank's loans that are past due and no longer accruing interest to the gross book value of the loan portfolio. Size is the natural logarithm of a bank's total assets. RWA / Total Assets is the ratio of a bank's risk-weighted assets to the book value of total assets. Return on Assets is the ratio of net income to the book value of total assets. Deposits / Total Liabilities is the ratio of a bank's customer deposits to the book value of total liabilities. Net Interest Margin is the ratio of a bank's net interest income to the book value of interest-bearing assets. Al accounting variables are taken from regulatory FR Y-9C filings for the fourth quarter of 2008. The table reports OLS coefficient estimates and (in parentheses) robust $t$-statistics. $* * * * *$, and $*$ indicate statistical significance at the $1 \%, 5 \%$, and $10 \%$ levels (two-tailed). 
Table 4: Adjustments of Recognized Loan Losses in the ECB's Asset Quality Review

Panel A: Magnitude of Loan Loss Adjustments at the Bank Level

\begin{tabular}{|c|c|c|c|c|c|c|c|}
\hline & & \multirow[b]{2}{*}{$\begin{array}{l}\text { CET1 Ratio } \\
\text { (before } \\
\text { AQR) }\end{array}$} & \multirow[b]{2}{*}{$\begin{array}{l}\text { Credit } \\
\text { Risk } \\
\text { RWA } \\
\end{array}$} & \multicolumn{4}{|c|}{ Loan Loss Provisions } \\
\hline & & & & $\begin{array}{c}\text { LLP } \\
\text { Adjustments } \\
(\mathrm{m} €)\end{array}$ & $\begin{array}{c}\text { LLP } \\
\text { Adjustments } \\
\text { (bp) }\end{array}$ & $\begin{array}{c}\% \text { of } \\
\text { Total } \\
\text { Assets }\end{array}$ & $\begin{array}{c}\% \text { of } \\
\text { Loan Loss } \\
\text { Allowance }\end{array}$ \\
\hline Banca Monte dei Paschi di Siena & IT & $10.19 \%$ & 66,667 & $4,180.39$ & 501 & $2.10 \%$ & $18.06 \%$ \\
\hline Piraeus Bank & GR & $13.68 \%$ & 56,277 & $2,709.43$ & 454 & $2.94 \%$ & $47.46 \%$ \\
\hline National Bank of Greece & GR & $10.69 \%$ & 49,461 & $2,247.16$ & 396 & $2.06 \%$ & $25.38 \%$ \\
\hline Rabobank & NL & $12.81 \%$ & 152,216 & $1,827.47$ & 87 & $0.27 \%$ & $21.30 \%$ \\
\hline Banco Popolare & IT & $10.06 \%$ & 35,911 & $1,560.93$ & 296 & $1.23 \%$ & $28.73 \%$ \\
\hline Commerzbank & $\mathrm{DE}$ & $11.39 \%$ & 158,998 & $1,492.23$ & 69 & $0.27 \%$ & $22.43 \%$ \\
\hline HSH Nordbank & $\mathrm{DE}$ & $10.00 \%$ & 49,680 & $1,432.73$ & 378 & $1.31 \%$ & $23.22 \%$ \\
\hline Erste Group Bank & AT & $11.17 \%$ & 84,857 & $1,370.74$ & 136 & $0.69 \%$ & $17.51 \%$ \\
\hline Eurobank Ergasias & GR & $10.62 \%$ & 33,606 & $1,278.16$ & 335 & $1.67 \%$ & $16.20 \%$ \\
\hline Groupe BPCE & FR & $10.32 \%$ & 343,616 & $1,118.17$ & 27 & $0.10 \%$ & $8.96 \%$ \\
\hline Alpha Bank & GR & $15.87 \%$ & 47,435 & $1,113.26$ & 215 & $1.51 \%$ & $16.00 \%$ \\
\hline Banco Comercial Português & PT & $12.22 \%$ & 40,526 & $1,107.16$ & 243 & $1.35 \%$ & $32.37 \%$ \\
\hline ING Bank & NL & $10.38 \%$ & 247,742 & $1,101.00$ & 37 & $0.14 \%$ & $17.95 \%$ \\
\hline UniCredit & IT & $9.77 \%$ & 315,919 & 972.61 & 24 & $0.11 \%$ & $2.08 \%$ \\
\hline Intesa Sanpaolo & IT & $11.95 \%$ & 241,492 & 972.19 & 34 & $0.18 \%$ & $3.35 \%$ \\
\hline \multicolumn{2}{|c|}{ All AQR Participants (n=130, Average) } & $14.15 \%$ & 52,536 & 330.57 & 73 & $0.41 \%$ & $15.53 \%$ \\
\hline \multicolumn{2}{|c|}{ All AQR Participants (n=130, Median) } & $12.29 \%$ & 20,117 & 62.08 & 28 & $0.12 \%$ & $8.96 \%$ \\
\hline \multicolumn{2}{|c|}{ All AQR Participants (n=130, StdDev) } & $7.82 \%$ & 91,614 & 594.50 & 11 & $0.70 \%$ & $22.29 \%$ \\
\hline \multicolumn{3}{|c|}{ \# AQR Participants with non-zero LLP Adjustments } & 112 & & & & \\
\hline
\end{tabular}


Panel B: Loan Loss Adjustments and Regulatory Capital

\begin{tabular}{|c|c|c|c|c|c|c|}
\hline \multirow[t]{2}{*}{ Dependent Variable: } & \multicolumn{3}{|c|}{ LLP Adjustments (bp) } & \multicolumn{3}{|c|}{ LLP Adjustments / Total Assets } \\
\hline & (1) & $(2)$ & (3) & (4) & (5) & $(6)$ \\
\hline \multicolumn{7}{|l|}{ Variables of Interest: } \\
\hline Low CET1 Ratio & & $\begin{array}{c}0.865^{* * *} \\
(3.45)\end{array}$ & $\begin{array}{c}0.810^{* * *} \\
(3.25)\end{array}$ & & $\begin{array}{c}0.005^{* * *} \\
(3.83)\end{array}$ & $\begin{array}{c}0.005^{* * *} \\
(3.71)\end{array}$ \\
\hline $\begin{array}{l}\text { Corrective Action Score } \\
\text { (Pre-AQR) }\end{array}$ & & & $\begin{array}{l}-0.620^{*} \\
(-1.74)\end{array}$ & & & $\begin{array}{l}-0.003^{*} \\
(-1.71)\end{array}$ \\
\hline \multicolumn{7}{|l|}{ Control Variables: } \\
\hline Size & $\begin{array}{l}0.008 \\
(0.08)\end{array}$ & $\begin{array}{l}0.025 \\
(0.27)\end{array}$ & $\begin{array}{l}0.090 \\
(0.89)\end{array}$ & $\begin{array}{l}-0.000 \\
(-0.45)\end{array}$ & $\begin{array}{l}-0.000 \\
(-0.20)\end{array}$ & $\begin{array}{l}0.000 \\
(0.42)\end{array}$ \\
\hline RWA / Total Assets & $\begin{array}{l}-0.000 \\
(-0.40)\end{array}$ & $\begin{array}{l}-0.000 \\
(-0.30)\end{array}$ & $\begin{array}{l}-0.000 \\
(-0.43)\end{array}$ & $\begin{array}{c}-0.001 * * \\
(-2.21)\end{array}$ & $\begin{array}{l}-0.000 \\
(-1.44)\end{array}$ & $\begin{array}{l}-0.000 \\
(-1.05)\end{array}$ \\
\hline Return on Assets & $\begin{array}{l}15.679 \\
(1.38)\end{array}$ & $\begin{array}{l}9.356 \\
(0.86)\end{array}$ & $\begin{array}{l}14.277 \\
(1.29)\end{array}$ & $\begin{array}{l}0.083 \\
(1.32)\end{array}$ & $\begin{array}{l}0.065 \\
(1.10)\end{array}$ & $\begin{array}{l}0.098 \\
(1.60)\end{array}$ \\
\hline Leverage Ratio & $\begin{array}{l}0.107 \\
(0.17)\end{array}$ & $\begin{array}{l}-0.023 \\
(-0.04)\end{array}$ & $\begin{array}{l}-0.030 \\
(-0.05)\end{array}$ & $\begin{array}{l}0.002 \\
(0.75)\end{array}$ & $\begin{array}{l}0.001 \\
(0.42)\end{array}$ & $\begin{array}{l}0.001 \\
(0.41)\end{array}$ \\
\hline Constant & Yes & Yes & Yes & Yes & Yes & Yes \\
\hline $\mathrm{R}^{2}$ & 0.039 & 0.182 & 0.218 & 0.151 & 0.298 & 0.328 \\
\hline \# Observations & 76 & 75 & 75 & 75 & 74 & 74 \\
\hline
\end{tabular}

The table summarizes the adjustments to the carrying amounts of banks' loan loss provisions for banks participating in the European Central Bank's (ECB) 2014 Asset Quality Review (AQR). The AQR formed part of the ECB's Comprehensive Assessment at the start of the Single Supervisory Mechanism in the Eurozone. Panel A reports the AQR results for the 15 banks with the largest adjustments (in million Euros) as well as summary statistics for all $130 \mathrm{AQR}$ participants. CET1 Ratio (before $A Q R$ ) is the bank's core equity tier 1 ratio at the end of 2013 (before the supervisory adjustment). Credit Risk RWA are a bank's total credit risk weighted assets including off-balance sheet items (in million Euros). LLP Adjustments are the additions to loan loss provisions on a bank's balance sheet for the fiscal year 2013 (in million Euros and in basis points of CET1 capital) according to the AQR. The additions are based on the ECB's individual assessment of a sample of non-performing loans, the projections of this assessment to the remaining portfolio of the banks, and additional provisions identified by a review of the provisioning models. We present the adjustments as a percentage of the bank's total assets as well as the total allowance for loan and lease losses. We take all accounting data from the S\&P Global Market Intelligence platform. Panel B reports the results of regressions of the LLP adjustments on a set of bank-specific characteristics. LLP Adjustments ( $b p$ ) is the AQR adjustment of a bank's loan loss provisions in basis points of CET1 capital and serves as the dependent variable in columns (1) through (3). LLP Adjustments / Total Assets is the AQR adjustment of a bank's loan loss provisions scaled by total assets. We derive both dependent variables from S\&P Global Market Intelligence. The independent variables include Low CET1 Ratio (an indicator variable that takes the value of 1 for banks in the lowest quartile of the CET1 ratio, 0 otherwise), Corrective Action Score (Pre-AQR) (the number of a bank's yearly dividend cuts, RWA cuts, leverage cuts, and capital issuances between 2012 and 2014 divided by 4), Size (the natural logarithm of a bank's total assets), RWA/Total Assets (a bank's risk-weighted assets scaled by total assets), Return on Assets (net income scaled by total assets), and Leverage Ratio (a bank's balance sheet liabilities, excluding deposits, scaled by total assets). The accounting data for all independent variables is measured in million USD at December 31, 2013 (source: BvD Bankscope). The table reports OLS coefficient estimates and (in parentheses) $t$-statistics. ${ }^{* * *}, * *$, and $*$ indicate statistical significance at the $1 \%, 5 \%$, and $10 \%$ levels (two-tailed). 
Table 5: Prudential Filters and Differences in Bank Characteristics

\begin{tabular}{|c|c|c|c|c|c|c|c|c|}
\hline \multirow[b]{3}{*}{ Balance Sheet Composition: } & \multicolumn{4}{|c|}{ 100\% AOCI Filter } & \multicolumn{4}{|c|}{$<100 \%$ AOCI Filter } \\
\hline & $N$ & Mean & P50 & $S D$ & $N$ & Mean & P50 & $S D$ \\
\hline & & & & & & & & \\
\hline Total Assets & 172 & 197,393 & 14,525 & 415,983 & 496 & 43,723 & 2,354 & 169,621 \\
\hline Cash \& Cash Equivalents & 171 & 0.035 & 0.016 & 0.045 & 496 & 0.020 & 0.013 & 0.030 \\
\hline AFS Securities & 160 & 0.117 & 0.089 & 0.110 & 490 & 0.110 & 0.092 & 0.010 \\
\hline Trading Assets & 149 & 0.085 & 0.065 & 0.089 & 392 & 0.065 & 0.034 & 0.083 \\
\hline Derivative Assets & 141 & 0.029 & 0.012 & 0.041 & 377 & 0.011 & 0.003 & 0.025 \\
\hline Loans & 168 & 0.665 & 0.666 & 0.160 & 495 & 0.750 & 0.777 & 0.137 \\
\hline Held-to-Maturity Assets & 91 & 0.035 & 0.005 & 0.079 & 159 & 0.039 & 0.013 & 0.059 \\
\hline Risk-Weighted Assets & 147 & 0.584 & 0.570 & 0.225 & 405 & 0.698 & 0.714 & 0.193 \\
\hline Long-Term Funding & 163 & 0.345 & 0.273 & 0.257 & 469 & 0.631 & 0.705 & 0.282 \\
\hline Leverage & 172 & 0.908 & 0.924 & 0.075 & 496 & 0.897 & 0.905 & 0.059 \\
\hline Tier 1 Ratio & 153 & 13.348 & 10.280 & 10.842 & 463 & 13.881 & 11.530 & 10.544 \\
\hline \multicolumn{9}{|l|}{ Equity Volatility: } \\
\hline Balance Sheet Equity & 282 & 3.86 & 1.51 & 6.48 & 182 & 3.83 & 2.10 & 5.19 \\
\hline Tier 1 Capital & 282 & 4.90 & 2.80 & 6.18 & 182 & 4.56 & 2.16 & 6.38 \\
\hline Total Regulatory Capital & 282 & 5.66 & 2.83 & 8.94 & 182 & 5.77 & 2.57 & 9.63 \\
\hline
\end{tabular}

The table provides summary statistics for bank characteristics, separately for banks that have a $100 \%$ AOCI filter as of the financial year 2006, and for other banks with different filter rules. The AOCI filter is $100 \%$ if unrealized FV losses from AFS debt securities do not affect a bank's regulatory capital, either because capital regulation in a bank's domicile adds back $100 \%$ of these losses or regulatory capital is based on local GAAP and hence FV losses reported in the IFRS financial statements are not relevant for regulatory capital. Countries with a $100 \%$ AOCI filter include Bahrain, Belgium, China, Denmark, France, Netherlands, Norway, Oman, Philippines, Poland, Russia, Singapore, Slovakia, Slovenia, South Africa, Sweden, and United Kingdom. Countries without a 100\% filter include Australia, Austria, Cyprus, Finland, Hong Kong, Hungary, Ireland, Jordan, Kazakhstan, Kuwait, Lithuania, Qatar, Saudi Arabia, Switzerland, Taiwan, Turkey, and United Arab Emirates. Germany, Italy, Portugal, and Spain did not have a 100\% filter in 2006 but changed their regulation later during our sample period. The sample comprises all banks from these countries using IFRS for financial reporting with non-missing observations for the year 2006 (source: BvD Bankscope). We report Total Assets in million USD. Cash \& Cash Equivalents, AFS Securities, Trading Assets, Derivative Assets, Loans, Held-to-Maturity Assets, and Risk-Weighted Assets are scaled by total assets. Long-Term Funding is scaled by total liabilities. Leverage is defined as the ratio of total liabilities to total assets. Tier 1 Ratio is defined as the ratio of tier 1 capital to total risk-weighted assets. For the computation of equity volatilities, we scale shareholders' equity by total assets and Tier 1 capital and total regulatory capital by total risk-weighted assets. Volatilities are computed as the standard deviation of these ratios over the 2001 to 2015 sample period and reported in percentage points. We require a minimum of five observations for each equity ratio for a bank to be included in the sample. We also require a minimum impact of the AFS portfolio on equity and exclude banks for which AFS assets make up less than 5\% of total assets. In this descriptive table, we exclude banks from the four countries that changed the prudential filter rules during our sample period. 
Table 6: Prudential Filters and Incentives for Early Corrective Actions

\begin{tabular}{|c|c|c|c|c|c|c|}
\hline \multirow{3}{*}{$\begin{array}{l}\text { Dependent Variable: } \\
\text { AFS Variable: }\end{array}$} & \multicolumn{5}{|c|}{ Corrective Action Score (\# Cuts) } & \multirow{3}{*}{ 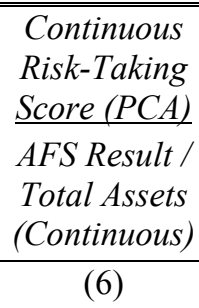 } \\
\hline & \multicolumn{5}{|c|}{ AFS Loss (Dummy) } & \\
\hline & (1) & (2) & (3) & (4) & (5) & \\
\hline \multicolumn{7}{|l|}{ Variables of Interest: } \\
\hline AFS Variable [t-1] & $\begin{array}{c}0.057^{* * *} \\
(3.11)\end{array}$ & $\begin{array}{c}0.065^{* * *} \\
(3.05)\end{array}$ & $\begin{array}{c}0.064 * * * \\
(2.80)\end{array}$ & $\begin{array}{c}0.094 * * * \\
(5.51)\end{array}$ & $\begin{array}{c}0.057 * * * \\
(2.88)\end{array}$ & $\begin{array}{c}0.117 * * * \\
(3.02)\end{array}$ \\
\hline AFS Variable $[\mathrm{t}-1] *$ Prudential Filter & $\begin{array}{c}-0.061 * * * \\
(-2.98)\end{array}$ & $\begin{array}{c}-0.069^{* * *} \\
(-3.05)\end{array}$ & $\begin{array}{c}-0.071 * * * \\
(-3.08)\end{array}$ & $\begin{array}{c}-0.096^{* * *} \\
(-3.27)\end{array}$ & $\begin{array}{c}-0.057^{*} \\
(-1.92)\end{array}$ & $\begin{array}{l}-0.070 \\
(-1.24)\end{array}$ \\
\hline AFS Variable & & $\begin{array}{l}0.030 \\
(1.63)\end{array}$ & $\begin{array}{l}0.026 \\
(1.57)\end{array}$ & $\begin{array}{l}0.001 \\
(0.07)\end{array}$ & $\begin{array}{l}0.015 \\
(0.87)\end{array}$ & $\begin{array}{c}0.085^{* * *} \\
(2.80)\end{array}$ \\
\hline AFS Variable * Prudential Filter & & $\begin{array}{c}-0.056^{* *} \\
(-2.05)\end{array}$ & $\begin{array}{c}-0.058^{* *} \\
(-2.08)\end{array}$ & $\begin{array}{l}-0.045^{*} \\
(-1.75)\end{array}$ & $\begin{array}{l}-0.032 \\
(-1.16)\end{array}$ & $\begin{array}{c}-0.120 * * * \\
(-2.78)\end{array}$ \\
\hline Prudential Filter & $\begin{array}{l}0.176 \\
(1.59)\end{array}$ & $\begin{array}{l}0.198^{*} \\
(1.72)\end{array}$ & $\begin{array}{l}0.206^{*} \\
(1.70)\end{array}$ & $\begin{array}{l}0.038 \\
(0.91)\end{array}$ & $\begin{array}{c}0.862 * * * \\
(17.12)\end{array}$ & $\begin{array}{l}-0.001 \\
(-0.42)\end{array}$ \\
\hline \multicolumn{7}{|l|}{ Control Variables: } \\
\hline Trading Result & $\begin{array}{c}-4.684 * * * \\
(-3.10)\end{array}$ & $\begin{array}{c}-4.787 * * * \\
(-3.13)\end{array}$ & $\begin{array}{c}-4.770 * * * \\
(-3.20)\end{array}$ & $\begin{array}{c}-2.504^{*} \\
(-1.78)\end{array}$ & $\begin{array}{c}-5.696 * * * \\
(-2.92)\end{array}$ & $\begin{array}{l}-0.011 \\
(-0.16)\end{array}$ \\
\hline Size & $\begin{array}{c}0.075^{* *} \\
(2.40)\end{array}$ & $\begin{array}{c}0.076^{* *} \\
(2.49)\end{array}$ & $\begin{array}{c}0.076^{* *} \\
(2.45)\end{array}$ & $\begin{array}{c}0.022 * * * \\
(5.98)\end{array}$ & $\begin{array}{c}0.143^{* *} \\
(2.54)\end{array}$ & $\begin{array}{l}-0.001 \\
(-1.24)\end{array}$ \\
\hline Size * Prudential Filter & $\begin{array}{l}0.001 \\
(0.08)\end{array}$ & $\begin{array}{l}0.002 \\
(0.19)\end{array}$ & $\begin{array}{l}0.001 \\
(0.13)\end{array}$ & $\begin{array}{l}0.006 \\
(1.24)\end{array}$ & $\begin{array}{l}0.004 \\
(1.58)\end{array}$ & $\begin{array}{l}0.000 \\
(0.13)\end{array}$ \\
\hline Return on Assets & $\begin{array}{l}-1.707^{*} \\
(-1.71)\end{array}$ & $\begin{array}{l}-1.685^{*} \\
(-1.71)\end{array}$ & $\begin{array}{l}-1.728^{*} \\
(-1.72)\end{array}$ & $\begin{array}{l}0.069 \\
(0.41)\end{array}$ & $\begin{array}{l}0.179 \\
(0.21)\end{array}$ & $\begin{array}{c}0.187^{* * *} \\
(3.55)\end{array}$ \\
\hline$\Delta$ Return on Assets & $\begin{array}{l}0.356 \\
(0.85)\end{array}$ & $\begin{array}{l}0.358 \\
(0.84)\end{array}$ & $\begin{array}{l}0.372 \\
(0.86)\end{array}$ & $\begin{array}{l}-0.414 \\
(-0.52)\end{array}$ & $\begin{array}{l}-0.669 \\
(-1.08)\end{array}$ & $\begin{array}{c}-0.101 * * * \\
(-3.59)\end{array}$ \\
\hline Total Capital Ratio & $\begin{array}{c}0.012 * * * \\
(4.13)\end{array}$ & $\begin{array}{c}0.012 * * * \\
(4.20)\end{array}$ & $\begin{array}{c}0.012 * * * \\
(4.14)\end{array}$ & $\begin{array}{l}0.000 \\
(0.87)\end{array}$ & $\begin{array}{c}0.009^{* *} \\
(2.29)\end{array}$ & $\begin{array}{c}-0.000^{* *} \\
(-2.05)\end{array}$ \\
\hline Total Capital Ratio * Prudential Filter & $\begin{array}{l}-0.005 \\
(-1.11)\end{array}$ & $\begin{array}{l}-0.005 \\
(-1.15)\end{array}$ & $\begin{array}{l}-0.005 \\
(-1.13)\end{array}$ & $\begin{array}{l}-0.001 \\
(-1.05)\end{array}$ & $\begin{array}{l}-0.000 \\
(-0.08)\end{array}$ & $\begin{array}{l}-0.000 \\
(-0.75)\end{array}$ \\
\hline Time FE & Year & Year & Year & Year & $\begin{array}{l}\text { Country } \mathrm{x} \\
\text { Year }\end{array}$ & Year \\
\hline Bank FE & Yes & Yes & Yes & No & Yes & Yes \\
\hline Country FE & No & No & No & Yes & No & \\
\hline Control for Continuous AFS Result & No & No & Yes & No & No & No \\
\hline Constant & Yes & Yes & Yes & Yes & Yes & Yes \\
\hline $\mathrm{R}^{2}$ & 0.094 & 0.097 & 0.098 & 0.084 & 0.330 & 0.181 \\
\hline \# Observations & 2,198 & 2,198 & 2,198 & 2,198 & 2,198 & 2,198 \\
\hline
\end{tabular}


We report the regression results for two different dependent variables. In columns (1) to (5), we use Corrective Action Score (\# Cuts) which is the sum of the values of Dividend Cuts, RWA Cuts, Leverage Cuts, and Capital Raising scaled by 4. In column (6), we use Risk-Taking Score (PCA) which is a composite score for each bank-year and derived from principal component analysis using the following four variables: Dividend Payouts, Risk-Weighted Assets, Leverage, and Share Capital. The score is the sum of the first two principal components, each weighted by the relative magnitude of their eigenvalues. Dividend Payouts is the amount of dividends paid out for the current fiscal year, scaled by total assets. Dividend Cuts takes a value of 1 if Dividend Payouts are lower than in the previous period, 0 otherwise. Risk-Weighted Assets is the ratio of risk-weighted assets to total assets. RWA Cuts takes a value of 1, if Risk-Weighted Assets are lower than in the previous period, 0 otherwise. Leverage is the ratio of liabilities (excluding customer deposits) to total assets. Leverage Cuts takes a value of 1, if Leverage is lower than in the previous period, 0 otherwise. Share Capital is the carrying amount of common stock and additional paid-in capital, scaled by total assets. Capital Raising takes a value of 1, if Share Capital is larger than in the previous periods, 0 otherwise. We use two different specifications for our AFS Variable of interest. In columns (1) to (5), AFS Loss takes a value of 1, if AFS Result is negative, 0 otherwise. In column (6), AFS Result is the sum of realized and unrealized gains and losses from AFS assets during the current period, scaled by total assets. Prudential Filter is a binary indicator that takes a value of 1 if FV losses from AFS debt securities do not affect a bank's regulatory capital, 0 otherwise (see Table 5 for further details). Trading Result is current period's income from trading assets, including derivatives, scaled by total assets. Size is the natural logarithm of total assets (in million USD). Return on Assets is net income (excluding Trading Result and the portion of the AFS Result that went through $\mathrm{P} \& \mathrm{~L}$ ), scaled by total assets. Total Capital Ratio is total regulatory capital (tier 1 and tier 2), scaled by risk-weighted assets. We include year and bank fixed effects in columns (1), (2), (3), and (6), year and country fixed effects in column (4), and country*year fixed effects in column (5), but do not report the coefficients. We can include country-by-year fixed effects because some banks use local GAAP for regulatory purposes. For these banks, the AFS Result in their IFRS financial statements does not reduce regulatory capital (which is why we code Prudential Filter as 1). The sample comprises all banks using IFRS for financial reporting from 39 countries with available bank-year observations over the 2001 to 2015 period (source: BvD Bankscope). The table reports OLS coefficient estimates and (in parentheses) $t$-statistics based on robust standard errors clustered by country. ${ }^{* *},{ }^{* *}$, and $*$ indicate statistical significance at the $1 \%, 5 \%$, and $10 \%$ levels (two-tailed). 


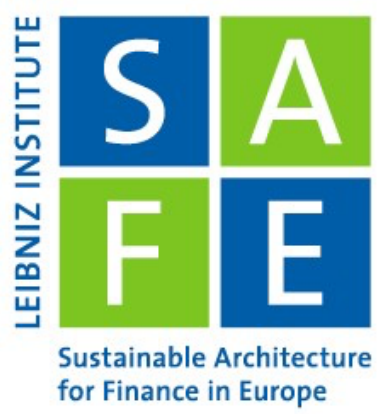

\section{Recent Issues}

No. 282 Daniel Munevar, Grygoriy Pustovit

No. 281 Kevin Bauer

No. 280 Konstantin Bräuer, Andreas Hackethal, Tobin Hanspal

No. 279 Tobin Hanspal, Annika Weber, Johannes Wohlfart

No. 278 Sandra Eckert

No. 277 Dominique M. Lammer, Tobin Hanspal, Andreas Hackethal

No. 276 Massimiliano Caporin, Loriana Pelizzon, Alberto Plazzi

No. 275 Loriana Pelizzon, Max Riedel, Zorka Simon, Marti Subrahmanyam

No. 274 Christopher Busch, Alexander Ludwig

No. 273 Di Bu, Tobin Hanspal, Yin Liao, Yong Liu

No. 272 Christine Laudenbach, Benjamin Loos, Jenny Pirschel, Johannes Wohlfart

No. 271 Pietro Dindo, Andrea Modena, Loriana Pelizzon

No. 270 Mario Bellia, Kim Christensen, Aleksey Kolokolov, Loriana Pelizzon, Roberto Renó

No. 269 Ester Faia, Maximilian Mayer, Vincenzo Pezone
Back to the Future: A Sovereign Debt Standstill Mechanism IMF Article VIII, Section 2 (b)

How did we do? The Impact of Relative Performance Feedback on Intergroup Hostilities

Consuming Dividends

Exposure to the COVID-19 Stock Market Crash and its Effect on Household Expectations

EU Agencies in Banking and Energy Between Institutional and Policy Centralisation

Who Are the Bitcoin Investors? Evidence from Indirect Cryptocurrency Investments

Does Monetary Policy Impact International Market Co-Movements?

Collateral Eligibility of Corporate Debt in the Eurosystem

Higher-Order Income Risk Over the Business Cycle

Financial Literacy and Self-Control in FinTech: Evidence from a Field Experiment on Online Consumer Borrowing

The Trading Response of Individual Investors to Local Bankruptcies

Risk Pooling, Leverage, and the Business Cycle

High-Frequency Trading During Flash Crashes: Walk of Fame or Hall of Shame?

The Value of Firm Networks: A Natural Experiment on Board Connections 